\title{
Caring for Refugees: Questioning the Public-Private Dichotomy in Canadian Resettlement
}

\author{
by
}

Rachel McNally

A thesis submitted to the Faculty of Graduate and Postdoctoral Affairs in partial fulfillment of the requirements for the degree of

Master of Arts

in

Political Science

Carleton University

Ottawa, Ontario

(C) 2020, Rachel McNally 


\begin{abstract}
While the Canadian refugee resettlement system has recently gained national and international attention following the resettlement of Syrian refugees, there are concerns that the government is privatizing its responsibilities. This thesis uses care ethics to understand the relationship between public and private actors within Canada's resettlement system. It questions a dichotomy between "public" and "private" resettlement and presents a more interdependent relationship between actors, revealing care relations that are often hidden. It illustrates how in the "public" Government-Assisted Refugee program, NGOs, volunteers, and sponsors play critical roles. Likewise, in the "private" sponsorship program, the government is involved in a number of substantive ways. By critically engaging with power hierarchies in relations of care, this thesis shows how different actors exercise power and experience vulnerability in different ways. It concludes by considering implications for contemporary discussions on resettlement and for Canada's efforts to promote refugee sponsorship to other countries.
\end{abstract}




\section{Acknowledgements}

I wrote this thesis in the midst of many challenges, from serious personal illness to a global pandemic. Because of the pandemic, I was not able to complete a second round of interviews and I will be defending this thesis virtually. Through it all, I have been grateful for the guidance, support, compassion, encouragement and flexibility of my supervisor Dr. James Milner. James is an incredible academic mentor, but he also cares about his students as people. His ability to take my scattered ideas and see the bigger picture is amazing. His excitement for my project helped me stay motivated when I was discouraged.

Thank you to Dr. Fiona Robinson for introducing me to care ethics and for helping me to understand the importance of care in resettlement and in the world. Thank you to my interview participants for generously giving your time to share your insights and for working every day to support refugees coming to Canada. Thank you to my parents, Catherine and John, and my brother Samuel, for being great quarantine buddies as I finished writing. Thank you to my roommate Hannah for sharing the thesis journey with me. Thank you to the Social Sciences and Humanities Research Council of Canada and the Department of Political Science for giving me funding so I could focus on my research. Thank you to Dr. Jacquie Newman, who gave helpful comments when I presented early findings from this research at the Atlantic Provinces Political Science Association conference in October 2019. I thank God who has given me strength and focus to persevere with this project through many challenges. Finally, thank you to all the resettled refugees whom I have had the privilege of knowing over the last few years. You are the reason I got into this work in the first place, and I hope that this work may help other refugees like you. 


\section{Table of Contents}

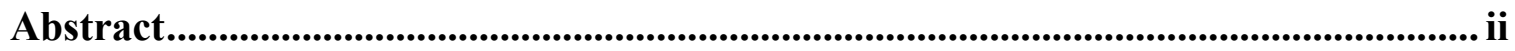

Acknowledgements ......................................................................................................ii

Table of Contents ............................................................................................................ iv

List of Tables .................................................................................................................................. vii

List of Figures....................................................................................................................... viii

List of Appendices......................................................................................................................... ix

List of Acronyms .......................................................................................................................... $\mathrm{x}$

Introduction .......................................................................................................................... 1

$1.1 \quad$ Research Questions and Central Argument..................................................................

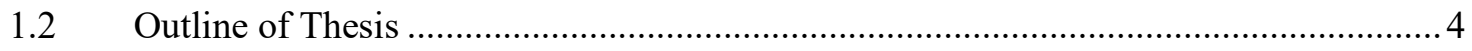

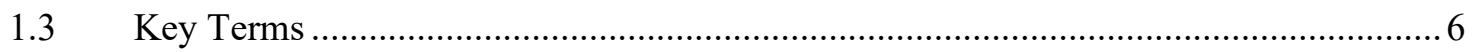

$1.4 \quad$ Methodology

Chapter 1: Refugee Resettlement in Canada: History and Context ........................... 19

$1.1 \quad$ Indochinese Resettlement and the Launch of Private Sponsorship ..............................22

1.2 Settlement Services: From the Government to NGOs and Volunteers ........................22

1.3 Government Funding, Sponsor Care: A History of Blended Programs ……………....25

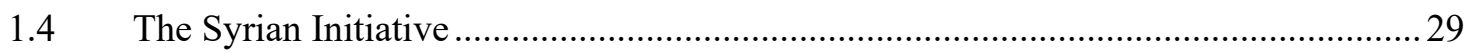

1.5 Post-Syrian Initiative: Yazidi Resettlement and Forty Years of Sponsorship...............30

1.6 Privatization and Private Sponsorship …………………………………………...... 33

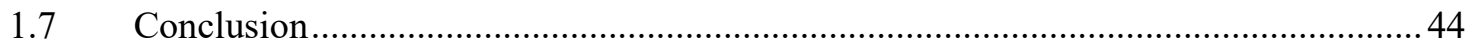

Chapter 2: Care and Resettlement: Making Care Visible .............................................. 45

2.1 Feminist Scholarship: Disrupting the Public-Private Dichotomy ………………….....45

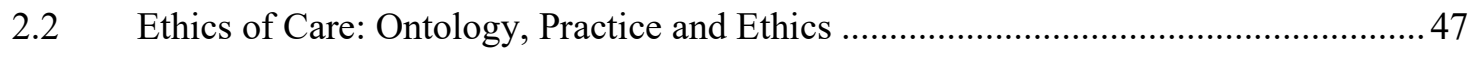

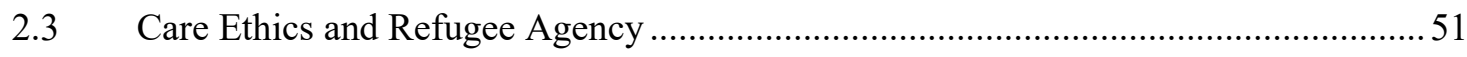




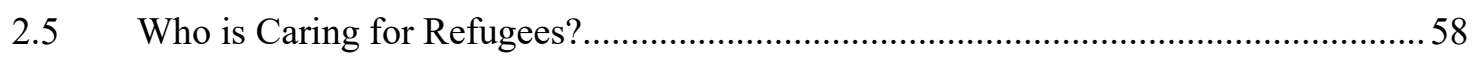

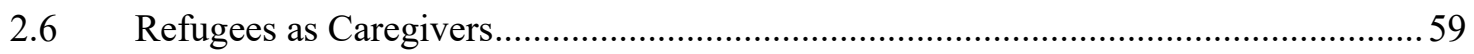

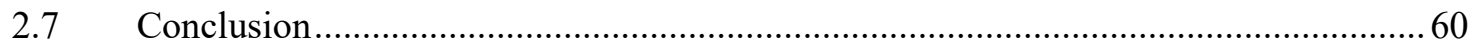

\section{Chapter 3: "Public" Resettlement: How NGOs, Volunteers and Sponsors Support} Government-Assisted Refugees .................................................................. 61

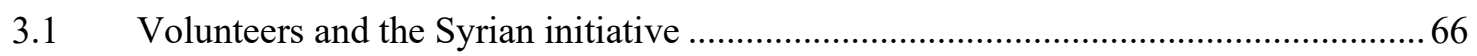

3.2 Yazidi Resettlement and In-Canada Joint Assistance Sponsorship............................ 70

3.3 Partnering to Care: Supporting Refugee Caregivers through JAS …......................... 78

3.4 Caring about Versus Care-Giving: The Government-NGO Power Hierarchy ..............78

3.5 A "Caring” Approach? Government Bureaucracy versus NGO Care ........................... 82

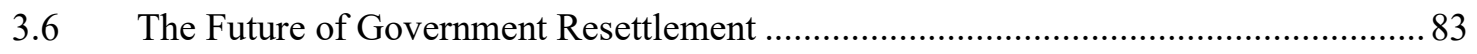

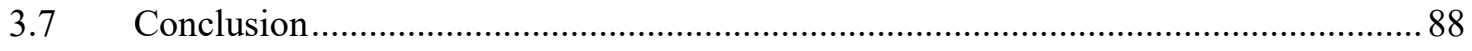

\section{Chapter 4: "Private" Resettlement: How the Government Supports Private} Sponsorship of Refugees..................................................................................8 89

4.1 Government Financial Contributions to Private Sponsorship .................................. 90

4.2 Sponsored Refugees and Government-Funded Settlement Services ...........................92

4.3 The Government-Sponsor Relationship ........................................................... 95

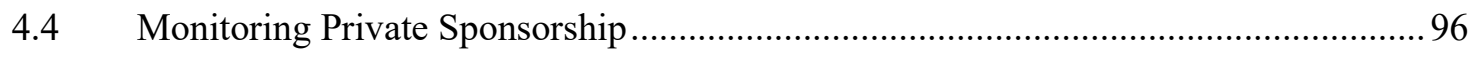

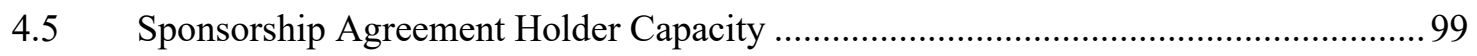

4.6 A "Caring” Approach? Government Bureaucracy versus Sponsor Care ................... 101

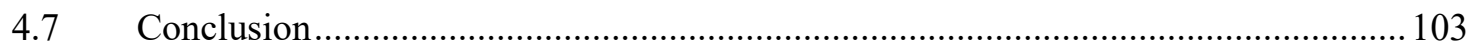

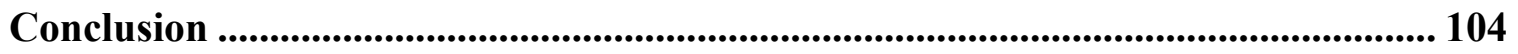

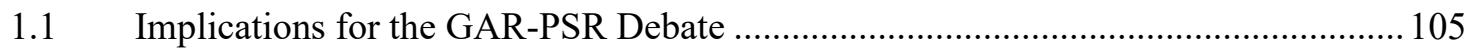

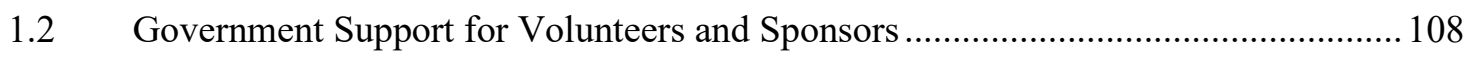

1.3 Principles for Cooperation: Listening, Responsiveness and Attentiveness ................ 109 


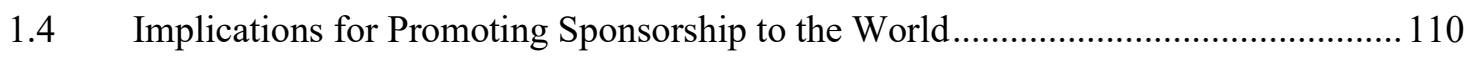

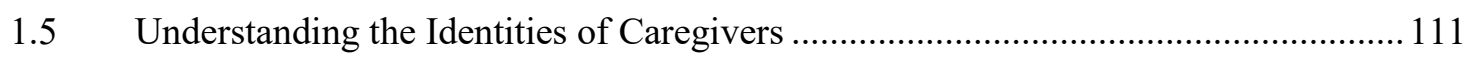

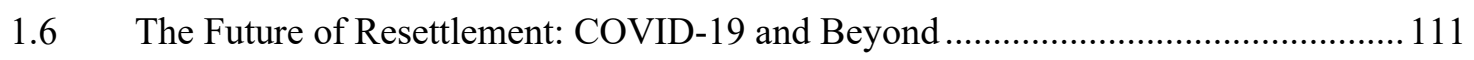

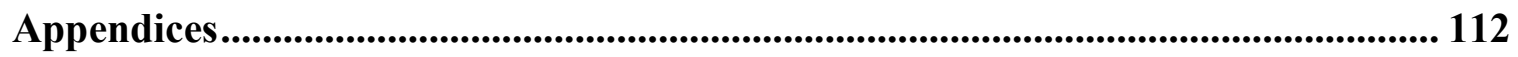

Appendix A Timeline of Refugee Resettlement in Canada................................................... 112

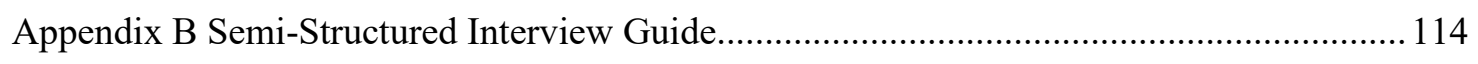

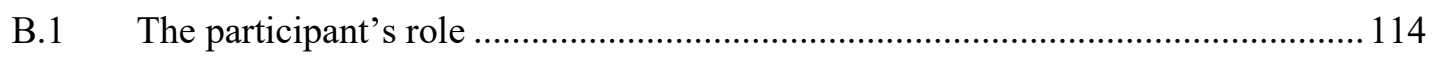

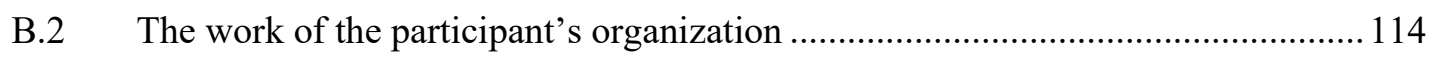

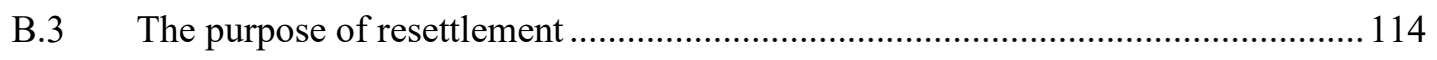

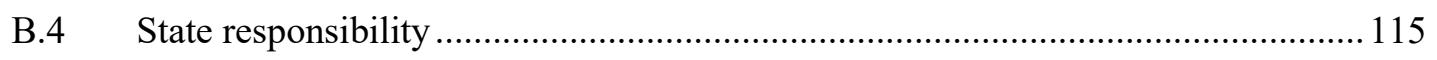

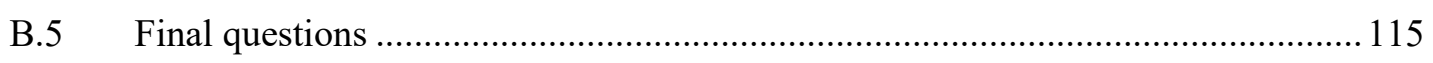

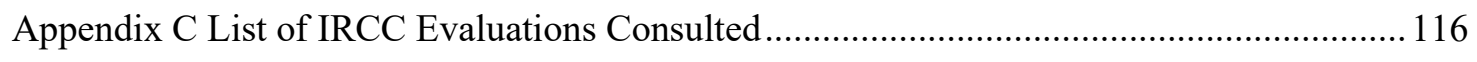

Appendix D List of Access to Information Requests Consulted ....................................... 117

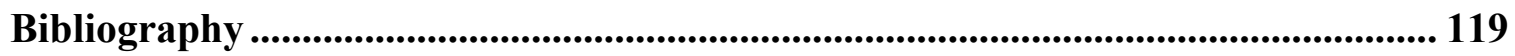




\section{List of Tables}

Table 1 Distribution of financial and caring responsibilities in Canada's main

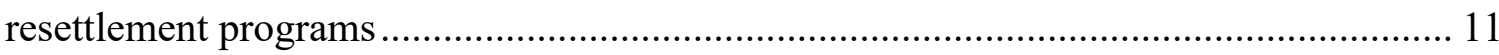

Table 2 Sponsorship Agreement Holders by Size of PSR Program ............................... 100

Table 3 Access to Information Requests Related to the Syrian Refugee Initiative ........ 117

Table 4 Additional Access to Information Requests ................................................... 118 


\section{List of Figures}

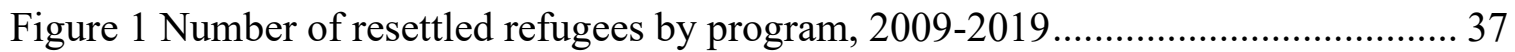

Figure 2 Models for Supporting UNHCR-Referred Refugees in Canada ....................... 62

Figure 3 Reasons for Referral to the Joint Assistance Sponsorship Program.................. 72 


\section{List of Appendices}

Appendix A Timeline of Refugee Resettlement in Canada....................... 112

Appendix B Semi-Structured Interview Guide................................ 114

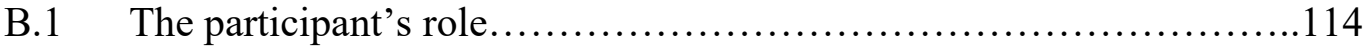

B.2 The work of the participant's organization..........................114

B.3 The purpose of resettlement................................. 114

B.4 State responsibility............................................ 115

B.5 Final questions............................................. 115

Appendix C List of IRCC Evaluations Consulted ............................116

Appendix D List of Access to Information Requests Consulted....................117 


\section{List of Acronyms}

BVOR - Blended Visa Office-Referred

CG - Constituent Group (local sponsorship group of a Sponsorship Agreement Holder)

GAR - Government-Assisted Refugee

GRSI - Global Refugee Sponsorship Initiative

IRCC - Immigration, Refugees and Citizenship Canada

JAS - Joint Assistance Sponsorship

NGO - Non-governmental organization

PSR - Private Sponsorship of Refugees

RAP - Resettlement Assistance Program

RAP-SPO - Resettlement Assistance Program Service Provider Organization

RSTP - Refugee Sponsorship Training Program

SAH - Sponsorship Agreement Holder (organization that has signed an Agreement with the Government of Canada to sponsor refugees)

SPO - Service Provider Organization (government-funded settlement agency)

UNHCR - Office of the United Nations High Commissioner for Refugees (also known as the UN Refugee Agency)

VOR - Visa Office-Referred 


\section{Introduction}

There are currently 26 million refugees in the world. ${ }^{1}$ In $2019,107,800$ of these refugees less than $0.5 \%$ - resettled to 26 countries, including 30,100 to Canada. ${ }^{2}$ Canada's refugee resettlement program has been the focus of significant domestic and global attention in recent years. In the last decade, Canada resettled $20 \%(210,600)$ of the 1.1 million refugees who resettled. ${ }^{3}$ Following the 2015 Liberal campaign promise to resettle 25,000 Syrian refugees, the Syrian initiative and the means by which Canada was able to resettle so many refugees in a relatively short period of time have attracted considerable attention from the media, the public and researchers. In 2019, Canada celebrated being the top resettlement country worldwide. ${ }^{4}$ However, this status was only achieved through counting the efforts of private sponsors in Canada's resettlement numbers, since despite its shrinking resettlement program, the United States still resettled more than double the number of refugees supported by the government in 2019 (21,159 compared to 9,031 refugees).$^{5}$ In the last decade, $58 \%$ of refugees resettled to Canada came through private sponsorship. ${ }^{6}$

In December 2016, the Government of Canada, in partnership with civil society actors and the Office of the United Nations High Commissioner for Refugees (UNHCR), launched the Global Refugee Sponsorship Initiative (GRSI) to promote private or

\footnotetext{
${ }^{1}$ UNHCR, “Global Trends: Forced Displacement in 2019” (Copenhagen, Denmark: UNHCR, June 18, 2020), 2, https://www.unhcr.org/5ee200e37.pdf.

${ }^{2}$ Ibid., 2, 48, 52.

3 Ibid., "Global Trends," 4, 52.

4 IRCC, "By the Numbers - 40 Years of Canada's Private Sponsorship of Refugees Program,” Government of Canada, April 9, 2019, https://www.canada.ca/en/immigration-refugees-citizenship/news/2019/04/bythe-numbers--40-years-of-canadas-private-sponsorship-of-refugees-program.html.

${ }^{5}$ UNHCR, "Resettlement Data Finder,” UNHCR, last modified March 31, 2020, https://rsq.unhcr.org/.

${ }^{6}$ UNHCR, "Global Trends," 52.
} 
community refugee sponsorship in other countries. ${ }^{7}$ This effort builds on Canada's history of refugee sponsorship: since its establishment in 1979, the private refugee sponsorship program has resettled some 327,000 refugees. ${ }^{8}$ As part of this initiative, Canada has hosted international delegations to learn about community sponsorship, and has sent members of Canada's refugee resettlement community around the world to share Canada's experience and to encourage other countries to adopt similar programs.

On the surface, it appears to be a Canadian good news story. Yet, long-standing tensions between public and private actors within the resettlement system complicate this simple narrative. First, the Government of Canada repeatedly takes credit for the work of sponsors, such as through including private sponsorship numbers in Canada's overall resettlement numbers. Given that individual sponsors and sponsoring organizations contribute one year of income support, start-up costs, in-kind donations, and an estimated 1,600 volunteer hours ${ }^{9}$ for each sponsored family, it raises questions over whether it is appropriate for the government to claim this work as part of Canada's resettlement efforts. ${ }^{10}$ Second, seeing resettlement primarily as a state responsibility, many scholars and refugee advocates have accused the government of privatizing its responsibilities, especially by increasing the number of refugees who are privately sponsored to a higher

\footnotetext{
${ }^{7}$ Global Refugee Sponsorship Initiative, "Who We Are," Global Refugee Sponsorship Initiative, accessed February 19, 2018, http://refugeesponsorship.org/who-we-are.

${ }^{8}$ IRCC, "By the Numbers."

${ }^{9}$ Canadian Council for Refugees, "The Private Sponsorship of Refugees Program: Current Challenges and Opportunities" (Canadian Council for Refugees, April 2006), 2, https://ccrweb.ca/en/private-sponsorshiprefugees-program-current-challenges-and-opportunities.

${ }^{10}$ Thea Enns, "The Opportunity to Welcome: Shifting Responsibilities and the Resettlement of Syrian Refugees within Canadian Communities" (Master's thesis, Oxford, University of Oxford, June 2017), 33, https://www.academia.edu/37800132/The_Opportunity_to_Welcome_Shifting_responsibilities_and_the_re settlement_of_Syrian_refugees_within_Canadian_communities.
} 
number than those who are supported by the government. ${ }^{11}$ Third, despite the importance of private sponsorship and the reliance on it to meet resettlement targets, the government frequently makes decisions that result in pushback from the sponsorship community, highlighting the power imbalance and the sometimes tense relationship between the government and sponsors. Finally, while private sponsorship and government-supported resettlement are intended to co-exist separately, recent developments such as the introduction of a new blended resettlement program have blurred distinctions between public and private resettlement. ${ }^{12}$ In response to these tensions, and at a time when Canada is promoting sponsorship in other countries, the goal of this thesis is to critically interrogate the resettlement process in Canada to develop a more nuanced understanding of the relationships between public and private actors, both in policy and in practice.

\subsection{Research Questions and Central Argument}

Further to this goal, this thesis asks: How do we understand and explain the complex and sometimes contradictory relationships between public and private actors in Canada's refugee resettlement process? Is there a clear distinction between the role of public and private actors in the resettlement process? What does an understanding of these relationships reveal about the functioning of Canada's refugee resettlement system?

To answer these research questions, this thesis uses care ethics to understand the relationship between public and private actors within Canada's refugee resettlement

\footnotetext{
${ }^{11}$ Canadian Council for Refugees, "2017 Immigration Levels - Comments," Canadian Council for Refugees, accessed January 19, 2019, https://ccrweb.ca/en/2017-immigration-levels-comments; Shauna Labman, "Private Sponsorship: Complementary or Conflicting Interests?," Refuge 32, no. 2 (2016): 67-80.

12 Shauna Labman and Madison Pearlman, "Blending, Bargaining, and Burden-Sharing: Canada's Resettlement Programs," Journal of International Migration and Integration, February 17, 2018, 1-11, https://doi.org/10.1007/s12134-018-0555-3.
} 
system. First, drawing on feminist scholarship, this thesis argues for the need to challenge the public-private dichotomy and presents a more interdependent relationship between the range of actors involved in the process of refugee resettlement. Second, by making visible concrete caring relations at different levels, this thesis argues for the need to go beyond institutional categories to capture the complexities of lived interactions. Finally, by accepting mutual dependency and vulnerability, and by critically engaging with power hierarchies within caring relations, this thesis argues for an understanding of the refugee resettlement process that reflects a more nuanced understanding of power that shows how different actors within the system exercise power and experience vulnerability in different ways. Overall, this thesis argues that all resettlement in Canada is a public-private partnership, with both public and private actors playing important roles in making the program possible and in caring for refugees.

\subsection{Outline of Thesis}

To support this argument, this thesis has four chapters. Chapter 1 gives context for the current resettlement system through a historical overview of the development of different refugee resettlement programs in Canada. Drawing on the literature on refugee sponsorship in Canada, it examines how tensions between public and private actors have developed over time and expands upon a narrative of privatization that features prominently in accounts of resettlement. The chapter notes how the history of resettlement has typically been told from the perspective of institutional actors, resulting in an emphasis on policies, programs and categories. Later chapters show how this institutional history misses important innovations in practice and simplifies complex categories and relationships. 
Chapter 2 introduces care ethics as an analytical lens. It argues that resettlement can usefully be seen as a form of care, raising critical questions around relations and responsibilities. Building on feminist scholarship more broadly, it breaks down apparent dichotomies between public and private. Ontologically, it proposes the mutual dependency, vulnerability and relationality of all individuals and actors. Using the concept of care also makes visible caring relations that may otherwise go unnoticed, and draws attention to hierarchies of power, but understanding that power also goes both ways.

Chapters 3 and 4 problematize the presumed public-private dichotomy in resettlement in Canada, first by showing the ways private actors are involved in supporting UNHCR-referred and government-selected refugees, and second by examining government supports for and involvement in private sponsorship. Chapter 3 argues that although resettlement is commonly seen as a state-led activity, and the "GovernmentAssisted" Refugee (GAR) program is seen as a "public" program, its implementation relies on various care arrangements involving NGO settlement agencies, sponsors, and volunteers. Although the Blended Visa Office-Referred program is framed as a publicprivate partnership, the GAR program is also a public-private partnership. The rise of innovative models to support Syrian GARs and the rise of the in-Canada Joint Assistance Sponsorship program responding primarily to the needs of Yazidi refugees both highlight the importance of volunteers and suggest that the broad "Government-Assisted Refugees" category obscures the diverse informal and formal caring relations on the ground.

Chapter 4 explores the idea of "private" sponsorship to suggest that even in the most privatized arrangement, the state is involved through screening, admittance, monitoring, public services, and some forms of settlement support. In particular, a trend 
toward increased settlement-sponsor collaboration further blurs the distinction between private and public as refugees access more government-funded services. It also argues that the portrayal of private sponsorship as "private" can have negative consequences, such as preventing refugees from accessing government-funded settlement services for which they are eligible. The chapter complicates a simple narrative of privatization. The thesis concludes considering the implications for contemporary discussions on resettlement in Canada and the promotion of Canada's approach in other countries.

\subsection{Key Terms}

As a basis for the work of this thesis, it is necessary to begin by defining key terms and concepts. First, the practice of care or caring has been defined as: "a species activity that includes everything that we do to maintain, continue, and repair our 'world' so that we can live in it as well as possible. That world includes our bodies, our selves, and our environment, all of which we seek to interweave in a complex, life-sustaining web."13 The concept of care will be explored in more detail in chapter 2 .

A refugee, according to the 1951 Convention Relating to the Status of Refugees, is a person who:

owing to well-founded fear of being persecuted for reasons of race, religion, nationality, membership of a particular social group or political opinion, is outside the country of his nationality and is unable or, owing to such fear, is unwilling to avail himself of the protection of that country; or who, not having a nationality and being outside the country of his former habitual residence as a result of such events, is unable or, owing to such fear, is unwilling to return to it. ${ }^{14}$

\footnotetext{
13 Joan Tronto, Moral Boundaries: A Political Argument for an Ethic of Care (New York: Routledge, $1993), 103$.

${ }^{14}$ UNHCR, "Convention and Protocol Relating to the Status of Refugees" (UNHCR, December 2010), https://www.unhcr.org/protection/basic/3b66c2aa10/convention-protocol-relating-status-refugees.html.
} 
Individuals who meet this definition, having a well-founded fear of persecution for one of the five "Convention grounds" and located outside of their country of origin, are considered "Convention refugees." In Canada's system, under the Immigration and Refugee Protection Regulations individuals may also qualify as refugees for the purpose of resettlement if they are outside of their country of origin and "have been, and continue to be, seriously and personally affected by civil war, armed conflict or massive violation of human rights." ${ }^{15}$ This category is called the Country of Asylum Class.

Individuals who are still within their country of origin are considered Internally Displaced Persons (IDPs) and do not normally qualify for resettlement, although the Canadian Minister of Immigration can make an exception under a public policy. These exceptions have been applied to various groups in the past, most recently in 2017 to Yazidis and other vulnerable survivors of Daesh (also known as ISIS) who were internally displaced within Iraq. Within refugee studies, labelling and categorizing is seen as an important form of power, as it determines access to certain benefits, such as access to resettlement spaces or eligibility for specific resettlement programs. ${ }^{16}$ In addition, this literature shows that despite the importance of bureaucratic labels, they fail to capture the complex lived experiences of refugees.

\footnotetext{
${ }^{15}$ Government of Canada, "Immigration and Refugee Protection Regulations," SOR/2002-227, last amended August 15, 2019, sec. 147, https://laws-lois.justice.gc.ca/PDF/SOR-2002-227.pdf. ${ }^{16}$ Roger Zetter, "Labelling Refugees: Forming and Transforming a Bureaucratic Identity," Journal of Refugee Studies 4, no. 1 (January 1991): 39-62, https://doi.org/10.1093/jrs/4.1.39; Roger Zetter, "More Labels, Fewer Refugees: Remaking the Refugee Label in an Era of Globalization," Journal of Refugee Studies 20, no. 2 (June 2007): 172-92, https://doi.org/10.1093/jrs/fem011; James Milner and Krystyna Wojnarowicz, "Power in the Global Refugee Regime: Understanding Expressions and Experiences of Power in Global and Local Contexts," Refuge: Canada's Journal on Refugees 33, no. 1 (March 2017): 717.
} 
Refugee resettlement can be defined as "the selection and transfer of refugees from a State in which they have sought protection to a third State which has agreed to admit them - as refugees - with permanent residence status. ${ }^{17}$ Resettlement is considered one of three "durable solutions" for refugees: returning home (voluntary repatriation), staying and integrating in the host country (local integration), or resettlement to a new country. ${ }^{18}$ For UNHCR, resettlement is "a tool to provide international protection" to individual refugees, "a durable solution for larger numbers or groups of refugees" alongside other solutions, and "a tangible expression of international solidarity and a responsibility sharing mechanism." ${ }^{19}$ There are two stated objectives of Canada's resettlement programs: first, "Canada contributes to international protection efforts and protects refugees" and second, "resettled refugees participate economically, socially and culturally in Canada."20

In Canada, immigration is a shared federal-provincial responsibility, but the federal government is responsible for facilitating refugee resettlement and for funding settlement services, which are implemented by settlement agencies. The department responsible for refugees is Immigration, Refugees and Citizenship Canada (IRCC) (previously called Citizenship and Immigration Canada). Generally the provincial and municipal services that refugees access are available to the general public instead of specific to immigrants or refugees, such as health care, education and public transit. ${ }^{21}$ In this thesis, unless otherwise noted, "the government" refers to the Canadian federal government.

\footnotetext{
${ }^{17}$ UNHCR, Resettlement Handbook(UNHCR, 2011), 3, https://www.unhcr.org/46f7c0ee2.html.

18 Ibid., 28.

19 Ibid., 36.

${ }^{20}$ Evaluation Division, "Evaluation of the Resettlement Programs (GAR, PSR, BVOR and RAP)" (Ottawa: IRCC, July 2016), 43, https://www.canada.ca/content/dam/ircc/migration/ircc/english/pdf/pub/resettlement.pdf.

${ }^{21}$ Evaluation Division, "Evaluation of the Settlement Program" (Ottawa: IRCC, November 2017), 4, 19, https://www.canada.ca/content/dam/ircc/documents/pdf/english/evaluation/e2-2016-settlement-en.pdf.
} 
As defined by the government, "Settlement refers to a short period of mutual adaptation between newcomers and the host society during which the government provides support and services to newcomers, while integration is a two-way process for immigrants to adapt to life in Canada and for Canada to welcome and adapt to new peoples and cultures" (emphasis added). ${ }^{22}$ One of the objectives of Canada's Immigration and Refugee Protection Act is to "to promote the successful integration of permanent residents into Canada, while recognizing that integration involves mutual obligations for new immigrants and Canadian society." 23 Since the Federal Integration Strategy of 1990, Canada has adopted a "two-way street" principle of mutual accommodation. ${ }^{24}$ However, despite a more comprehensive view of integration, and the use of indicators such as a sense of belonging to Canada, ${ }^{25}$ individual economic self-sufficiency is still prioritized, such as a recent commitment "to ensure the settlement needs of all resettled refugees are being met effectively and efficiently so that they can become self-sufficient faster."26

As described in this thesis, resettlement in Canada involves both government and civil society. Civil society has been defined as "all organizations, networks, and associations between the level of the family and the level of the state, except firms." ${ }^{27}$ This

\footnotetext{
22 Evaluation Division, "Rapid Impact Evaluation of the Syrian Refugee Initiative" (Ottawa: IRCC, December 2016), 3, https://www.canada.ca/en/immigration-refugees-citizenship/corporate/reportsstatistics/evaluations/rapid-impact-evaluation-syrian-refugee-initiative.html.

${ }^{23}$ Government of Canada, "Immigration and Refugee Protection Act," S.C. 2001, c. 27, last amended July 31, 2018, sec. 3(1)(e), http://laws-lois.justice.gc.ca/eng/acts/I-2.5/page-1.html\#h-3.

${ }^{24}$ Evaluation Division, "Evaluation of the Host Program" (Ottawa: Citizenship and Immigration Canada, 2010), 7, https://www.canada.ca/content/dam/ircc/migration/ircc/english/pdf/research-stats/2010-eval-hosteng.pdf.

${ }^{25}$ Evaluation Division, "Evaluation of the Syrian Initiative," 23.

${ }^{26}$ Minister of IRCC, “Departmental Plan 2019-2020” (Ottawa: IRCC, 2019), 19, https:/www.canada.ca/content/dam/ircc/migration/ircc/english/pdf/pub/dp-pm-2019-2020-eng.pdf.

${ }^{27}$ Michael Edwards and Simon Zadek, "Governing the Provision of Global Public Goods: The Role and Legitimacy of Nonstate Actors," in Providing Global Public Goods: Managing Globalization, ed. Inge Kaul (New York: Oxford University Press, 2003), 201, http://www.oxfordscholarship.com/view/10.1093/0195157400.001.0001/acprof-9780195157406.
} 
broad definition includes non-governmental organizations (NGOs), settlement agencies, and all types of sponsorship groups in Canada, from more institutionalized groups like church denominations to informal community groups. Private actors include civil society, businesses and individuals, while public or state actors include governments at all levels.

A Service Provider Organization (SPO) is a settlement agency that has a contribution agreement with IRCC to deliver settlement services. Settlement services are open to all permanent residents in Canada (including all resettled refugees) and cover six areas (Needs Assessments and Referrals, Information and Orientation, Language Assessments, Language Training, Employment-Related Services and Community Connections), six support services to facilitate access to settlement services (Care for Newcomer Children, Transportation, Translation, Interpretation, Disability Support and Crisis Counselling), and various capacity-building and partnership initiatives that support settlement services, such as Local Immigration Partnerships. ${ }^{28}$

Canada's resettlement programs can be differentiated based on how responsibilities are distributed between the government and sponsors, both financial and settlement support, including emotional, social and practical support. In the Government-Assisted Refugees (GAR) program, the government provides full income support for one year under the Resettlement Assistance Program (RAP). The RAP program also includes six weeks of initial services for GARs, provided by settlement agencies, including welcome at the airport, temporary accommodation, basic orientation to Canada, life skills training, and

\footnotetext{
${ }^{28}$ Evaluation Division, "Evaluation of the Settlement Program," vi.
} 
assistance in finding permanent accommodation. ${ }^{29}$ After the six weeks, GARs transition to settlement services that are available to all permanent residents. In Private Refugee Sponsorship (PSR), sponsors provide full income support and settlement services. In between these two models are blended programs that combine government and sponsor support: the Joint Assistance Sponsorship program (JAS) and the Blended Visa OfficeReferred program (BVOR). In the BVOR program, sponsors are financially responsible for the first month including start-up and income support for months 8-12, while the government offers income support for months 2-7.

Table 1 Distribution of financial and caring responsibilities in Canada's main resettlement programs

\begin{tabular}{|l|l|l|l|l|}
\hline Program & $\begin{array}{l}\text { Government- } \\
\text { Assisted Refugees } \\
\text { (GAR) }\end{array}$ & $\begin{array}{l}\text { Joint Assistance } \\
\text { Sponsorship (JAS) }\end{array}$ & $\begin{array}{l}\text { Blended Visa } \\
\text { Office-Referred } \\
\text { (BVOR) }\end{array}$ & $\begin{array}{l}\text { Private } \\
\text { Sponsorship } \\
\text { of Refugees } \\
\text { (PSR) }\end{array}$ \\
\hline Who pays? & State & State & State \& sponsors & Sponsors \\
\hline $\begin{array}{l}\text { Who } \\
\text { cares? }\end{array}$ & $\begin{array}{l}\text { Government-funded } \\
\text { settlement agencies }\end{array}$ & $\begin{array}{l}\text { Sponsors \& } \\
\text { government-funded } \\
\text { settlement agencies }\end{array}$ & Sponsors & Sponsors \\
\hline
\end{tabular}

To qualify for JAS, refugees must meet special needs criteria, such as a large family size or unusual family configuration (such as an older sibling caring for younger siblings), significant medical needs or a disability, trauma from violence or torture, effects of systematic discrimination, illiteracy or limited education, elderly, or women at risk. ${ }^{30}$ Today, there are two variations of the JAS program. In the overseas variation, Canadian visa officers identify that refugees meet the JAS criteria, and refer them to be matched with

${ }^{29}$ IRCC, "Resettlement Assistance Program (RAP)," Government of Canada, last modified June 19, 2019, www.canada.ca/en/immigration-refugees-citizenship/corporate/publications-manuals/operational-bulletinsmanuals/service-delivery/resettlement-assistance-program.html, Government of Canada.

${ }^{30}$ Refugee Sponsorship Training Program, "The Joint Assistance Sponsorship (JAS) Program," RSTP, accessed May 24, 2020, http://www.rstp.ca/en/jas/joint-assistance-sponsorships/. 
a sponsor in Canada before they can travel. In the in-Canada variation, settlement workers who are struggling to meet the needs of a particular GAR family can refer that family to be matched with a sponsor. ${ }^{31}$ The government continues to provide full financial support and initial services through the RAP, but sponsors take over the majority of ongoing settlement support. The government and sponsors provide support for 24 months (instead of the usual 12 months), and sometimes up to 36 months.

There are two ways refugees are selected for resettlement to Canada. First, a Canadian visa office may select a refugee, usually based on a referral by the UNHCR. These are commonly called "visa office-referred" refugees, and they may arrive through the GAR, BVOR or JAS programs. The UNHCR identifies refugees for resettlement based on needs and vulnerability according to seven categories: legal and/or physical protection needs, survivors of torture and/or violence, medical needs, women and girls at risk, family reunification, children and adolescents at risk, and lack of foreseeable alternative durable solutions. ${ }^{32}$ According to this criteria, UNHCR estimates that over 1.4 million refugees need resettlement, yet given limited resettlement spaces, it could only refer about 81,000 refugees for resettlement in $2019 .{ }^{33}$ Second, in the PSR program, the sponsorship group may "name" a refugee, frequently a family member, that they wish to sponsor.

There are three kinds of sponsorship groups in Canada. Sponsorship Agreement Holders (SAHs) are organizations that have signed an agreement with the Canadian

\footnotetext{
${ }^{31}$ IRCC, "Immigration Operational Bulletin 646 (Modified) - Joint Assistance Sponsorship Recommendations from within Canada," Government of Canada, December 6, 2017, https:/www.canada.ca/en/immigration-refugees-citizenship/corporate/publications-manuals/operationalbulletins-manuals/bulletins-2017/646.html.

${ }^{32}$ UNHCR, Resettlement Handbook, 37.

${ }^{33}$ UNHCR, "Global Trends," 51.
} 
government to sponsor refugees. As of November 2019, there were 124 SAHs across Canada, including long-established religious organizations, ethno-cultural organizations, some settlement agencies, and various humanitarian and community organizations. ${ }^{34}$ Since SAHs are often national or regional organizations, they frequently have Constituent Groups (CGs) in local communities that act as sponsorship groups (such as local churches for a national church denomination), while the $\mathrm{SAH}$ is responsible for submitting the application, training sponsors, and monitoring. Sponsorship groups may also be Community Sponsors, which are "organizations, associations or corporations," or Groups of 5, which as the name suggests refers to groups of five or more Canadian citizens or residents who form a group to sponsor a refugee. ${ }^{35}$

This thesis talks about volunteering and sponsorship as ways that civil society may be involved in supporting refugees. Sponsorship involves signing a legal undertaking with the government, whereas volunteering involves a commitment to a specific organization. One report defines volunteering as primarily task-specific, whereas sponsorship "gives an individual or a group responsibility for [integration] outcomes. ${ }^{\prime 36}$ However, like this thesis, it sees volunteering and sponsorship as "points along a continuum" that are not necessarily mutually exclusive or the only forms of community support for refugees. ${ }^{37}$

\footnotetext{
${ }^{34}$ Government of Canada, "Private Sponsorship of Refugees Program - Sponsorship Agreement Holders," Government of Canada, last modified November 25, 2019, https://www.canada.ca/en/immigrationrefugees-citizenship/services/refugees/help-outside-canada/private-sponsorship-program/agreementholders/holders-list.html\#tbl.

35 Government of Canada, "Sponsor a Refugee," Government of Canada, last modified December 3, 2019, https://www.canada.ca/en/immigration-refugees-citizenship/services/refugees/help-outside-canada/privatesponsorship-program.html.

${ }^{36}$ Susan Fratzke and Emma Dorst, "Volunteers and Sponsors: A Catalyst for Refugee Integration?" (Migration Policy Institute, November 25, 2019), 4, https://www.migrationpolicy.org/research/volunteerssponsors-refugee-integration.

${ }^{37}$ Ibid., 4.
} 


\subsection{Methodology}

This thesis takes a mixed methods approach, drawing on my personal engagement with Canada's refugee resettlement system in different roles, a literature review, document analysis, and semi-structured interviews with key informants who work in Canada's resettlement system. First, this thesis builds on five years of my personal, professional and academic engagement with refugee resettlement in Canada. Like many Canadians, my journey with refugees started in 2015 when I joined a refugee sponsorship group at my church. I have since been involved with the sponsorship of three families: two Somali families who were living in refugee camps in Kenya, and one Syrian family. Two of these families came through the BVOR program, and the other came through PSR as a family reunification case. In the summer of 2016, I worked for a regional SAH, the Canadian Baptists of Atlantic Canada, assisting with the administration of their sponsorship program and developing training materials for sponsors. In the context of the Syrian initiative, at the time the SAH was overseeing the sponsorship of over 300 refugees, with over 100 churches involved from small and large communities across the four Atlantic provinces.

In the summer of 2017, as part of my Honours thesis with Acadia University on refugee sponsorship in rural Nova Scotia, I conducted twenty-two semi-structured interviews with sponsors, SAH staff, settlement workers, local politicians and sponsored refugees. This research led to my involvement in an edited book project on refugee sponsorship, due to be published in September $2020 .{ }^{38}$ Interacting with the other authors as part of this project has been formative in my thinking on refugee sponsorship, especially

\footnotetext{
${ }^{38}$ Rachel McNally, "The Blended Visa Office-Referred Program: Perspectives and Experiences from Rural Nova Scotia," in Strangers to Neighbours: Refugee Sponsorship in Context, ed. Shauna Labman and Geoffrey Cameron (Montreal: McGill-Queen’s University Press, forthcoming 2020).
} 
on the various ways to define success in a refugee sponsorship program, ${ }^{39}$ and several chapters in the book are cited in this thesis. Finally, in the winter of 2019, I was an intern with UNHCR Canada in the Resettlement and Durable Solutions Unit. This internship gave me a broader understanding of the policies, institutions and politics of resettlement. These experiences, particularly the UNHCR internship, helped me to build networks that led to contacts for the interviews for this project.

I acknowledge my own positionality as a Canadian-born, active participant in Canada's refugee resettlement system. As a result of my involvement, I have certain biases. I am supportive of resettlement and sponsorship, and ultimately I want to see resettlement succeed and improve. However, I also recognize various shortcomings and critiques of these programs. In this thesis, I aim to consider and incorporate multiple perspectives. I also do not claim to speak for refugees, as that is not my experience.

This thesis primarily engages with two sets of literature. First, it reviews the academic and grey literature on refugee sponsorship in Canada. Although private sponsorship has existed in Canada for over forty years, up until recently, there was little literature on the topic. ${ }^{40}$ Since 2016, two special issues of the journal Refuge, studies on Syrian resettlement, and ongoing projects have contributed greatly to understanding the history, politics, and implications of private sponsorship. When relevant, this literature has been incorporated into chapter 1 . Literature that speaks specifically to the sponsorsponsored relationship and the demographics of sponsors is incorporated into chapter 2 .

\footnotetext{
${ }^{39}$ Rachel McNally, "15 Ways to Evaluate the Success of Community Sponsorship Programs," Canadian Association for Refugee and Forced Migration Studies (blog), January 22, 2020, http://carfms.org/15-waysto-evaluate-the-success-of-community-sponsorship-programs-by-rachel-mcnally/.

${ }^{40}$ Johanna Reynolds and Christina Clark-Kazak, "Introduction: Special Issue on Private Sponsorship in Canada," Refuge: Canada's Journal on Refugees 35, no. 2 (September 2019): 3.
} 
Second, this thesis draws on the literature of care ethics and feminist scholarship more broadly. This literature will be explored in chapter 2 .

In a contemporary policy setting, sources that may be used as "archival materials" include reports by governments, UNHCR, NGOs, and transcriptions of parliamentary debates. ${ }^{41}$ For government documents, I reviewed eight years of annual reports from IRCC: the Annual Reports to Parliament on Immigration (2012-2019), ${ }^{42}$ the Departmental Plan (2013/14-2020/21), ${ }^{43}$ and the Departmental Results Reports (2011/12-2018/19). ${ }^{44}$ I also reviewed ten IRCC program evaluations (see the list in Appendix C).$^{45}$ I reviewed documents obtained through 16 Access to Information requests, six of which were about the Syrian initiative (see a list in Appendix D). With one exception, these were requests for previously released information. I also reviewed operational bulletins and press releases.

In addition, I reviewed documents from NGOs. First, I reviewed eight statements or documents from the Canadian Council for Refugees, an umbrella advocacy organization. I also reviewed six years (2014-2019) of the bi-weekly informational bulletins published by the Refugee Sponsorship Training Program (RSTP), which provide program updates to sponsors and promote profiles of refugees requiring sponsors, for a total of 125 bulletins. ${ }^{46}$ Analysis of the JAS program in Chapter 3 is based in part on an analysis of 119 case profiles

\footnotetext{
${ }^{41}$ James Milner, “Can Global Refugee Policy Leverage Durable Solutions? Lessons from Tanzania's Naturalization of Burundian Refugees," Journal of Refugee Studies 27, no. 4 (December 2014): 555, https://doi.org/10.1093/jrs/feu023.

42 IRCC, accessed May 16, 2020, available at https://www.canada.ca/en/immigration-refugeescitizenship/corporate/publications-manuals.html and http://www.publications.gc.ca/site/eng/359079/publication.html.

${ }^{43}$ IRCC, accessed May 16, 2020, available at https://www.canada.ca/en/immigration-refugeescitizenship/corporate/publications-manuals.html.

${ }^{44}$ IRCC, accessed May 16, 2020, available at https://www.canada.ca/en/immigration-refugeescitizenship/corporate/publications-manuals/departmental-performance-reports.html.

45 IRCC, accessed May 16, 2020, available at https://www.canada.ca/en/immigration-refugeescitizenship/corporate/reports-statistics/evaluations.html.

${ }^{46}$ Refugee Sponsorship Training Program, available at http://www.rstp.ca/en/bulletins/.
} 
(19 overseas JAS cases, 100 in-Canada JAS cases), taken from all the short profiles featured in RSTP bulletins from 2014-2019 as well as the 18 longer profiles of cases available for sponsorship on the RSTP website on September 4, 2019. ${ }^{47}$ Although this is not a random sample and is not statistically representative of all JAS profiles, it gives an idea of the range of JAS profiles in the absence of more comprehensive data.

Finally, I conducted semi-structured key informant interviews (see appendix B for the interview guide). The research was approved by the Carleton University Ethics Board, CUREB-A Clearance \# 111055. In semi-structured interviews, the interview guide offers open-ended questions and general themes, and the researcher asks more specific questions based on the specific expertise of the participant. ${ }^{48}$ Participants also have the opportunity at the end of the interview to raise themes that may not be included in the interview guide. Participants were identified via publicly available contact information, personal contacts of the researcher further to the UNHCR internship, and snowball sampling. Interviews were conducted in person, over the phone or via video call. Interviews lasted between 30 minutes and 1 hour 15 minutes. Participants could choose how they wished to be identified or remain anonymous. Participants were also given the opportunity to revise or clarify their quotes before they were included in the thesis or keep specific quotes anonymous.

In total, I conducted eight interviews in late 2019 and early 2020. The original intention was to conduct a second round of interviews in March 2020. However, due to the COVID-19 pandemic, it was not possible to interview representatives from the government

\footnotetext{
${ }^{47}$ Excluding duplicates and linked cases. Refugee Sponsorship Training Program, "JAS Refugee Profiles," RSTP, accessed September 4, 2019, http://www.rstp.ca/en/jas/jas-profiles/.

${ }^{48}$ Herbert Rubin and Irene Rubin, Qualitative Interviewing: The Art of Hearing Data, 3rd ed. (Thousand Oaks: SAGE, 2012).
} 
and several other organizations. As a result, these perspectives are only included indirectly through document analysis. This methodology has limitations. The small number of interviews limits generalizability. The sponsorship and the settlement communities are diverse, and this thesis cannot claim to represent all of these perspectives. However, interview participants represented a wide range of perspectives, including settlement agencies, SAHs and UNHCR. Many interviewees have decades of experience in resettlement and frequent interactions with others who are involved in resettlement, such as through the Council which represents SAHs across the country. They provided a broad perspective and identified different perspectives within the sponsorship community. Although this thesis can problematize the public-private dichotomy, future research would be necessary to capture the complexity of the roles and relationships within the system.

This thesis also has geographic limitations. Since Quebec has its own resettlement and sponsorship programs, it was not considered in the thesis. Although the findings have implications for Canada's efforts to promote sponsorship overseas, this thesis is not comparative, and the findings are not generalizable beyond Canada. While there is literature from the United States on public-private partnerships in resettlement, only literature from Canada is included given major differences in the resettlement system.

As detailed in this introduction, refugee resettlement in Canada includes a complex set of actors and institutional categories. However, these categories do not fully capture the care relations in practice, nor do they reveal the controversies behind the programs. The next chapter presents a historical context for the resettlement system, exploring how tensions between public and private actors have developed over time. 


\section{Chapter 1: Refugee Resettlement in Canada: History and Context}

This chapter reviews the history of the relationship between private and public actors within Canada's refugee resettlement system and explores the recurring narrative of privatization within the literature on private sponsorship (see also Appendix A which provides an accompanying timeline of events). While it is outside of the scope of this thesis to engage with broader discussions of immigration policy, it is important to recognize that refugee resettlement in Canada happens within a broader national and international context that includes immigration policy, Canada's engagement with refugees globally, Canada's in-country asylum system, and a history of settler colonialism and race-based immigration policies, issues that scholars have discussed in detail elsewhere. ${ }^{49}$ Hyndman and colleagues note that due to its geography far away from many refugee-producing countries "Canada has long had the luxury of choosing most of its immigrants, and refugees" resulting in an immigration system based on careful selection and a focus on resettlement over spontaneous asylum. ${ }^{50}$ Although in 2018 Canada resettled 28,076 refugees, resettled refugees made up only about $9 \%$ of Canada's immigrants, compared to $58 \%$ for economic

\footnotetext{
${ }^{49}$ For more on the evolution of increasingly restrictive asylum policies alongside generous resettlement policies, see Shauna Labman, Crossing Law's Border: Canada's Refugee Resettlement Program, Law and Society Series (Vancouver: UBC Press, 2019). For reflections on how sponsorship influences Canada's international engagement with refugees, see Megan Bradley and Cate Duin, "A Port in the Storm: Resettlement and Private Sponsorship in the Broader Context of the Refugee Regime," in Strangers to Neighbours: Refugee Sponsorship in Context, ed. Shauna Labman and Geoffrey Cameron (Montreal: McGill-Queen's University Press, forthcoming 2020). For more on the discourses and policies of Canada's immigration history, see Ninette Kelley and Michael Trebilcock, The Making of the Mosaic: A History of Canadian Immigration Policy, 2nd ed. (Toronto: University of Toronto Press, 2010).

${ }^{50}$ Jennifer Hyndman, William Payne, and Shauna Jimenez, "The State of Private Refugee Sponsorship in Canada: Trends, Issues, and Impacts" (Refugee Research Network and York University Centre for Refugee Studies, December 2, 2016), 11, http://refugeeresearch.net/wpcontent/uploads/2017/02/hyndman_feb\%E2\%80\%9917.pdf.
} 
immigrants. ${ }^{51}$ Historically, from 2001 to 2014 , resettled refugees made up between 4 and $5 \%$ of the immigration applications approved each year. ${ }^{52}$

Although 1979 is considered the official launch of Canada's sponsorship program, Canada had previously resettled refugees under economic immigration programs, government resettlement programs, and pre-cursors to private sponsorship. Between 1923 and 1930, Mennonite Central Committee helped resettle over 21,000 Mennonites from the Soviet Union to Canada. ${ }^{53}$ Following the Second World War, between 1947 and 1952, 250,000 displaced persons from Central and Eastern Europe resettled to Canada. ${ }^{54}$ Many of these European refugees were selected to meet Canada's labour needs and arrived through the "bulk labour" program, while others came through a "close relatives" program, in which religious organizations played an important role. ${ }^{55}$ Around 60,000 of the European refugees who resettled in Canada between April 1947 and March 1952, and nearly all of the 37,000 Hungarian refugees who resettled to Canada in 1956 following the anti-communist uprising came through sponsorship by a religious organization, setting a precedent for later sponsorship initiatives. ${ }^{56}$

\footnotetext{
${ }^{51}$ Minister of Immigration, Refugees and Citizenship, "2019 Annual Report to Parliament on Immigration" (Ottawa: IRCC, 2019), 37, https://www.canada.ca/content/dam/ircc/migration/ircc/english/pdf/pub/annualreport-2019.pdf.

${ }^{52}$ Calculated by the author based on IRCC, "Permanent Resident Applications Processed by Year, Immigration Category and Application Status (in persons) 2000-2017," obtained under Access to Information Request A-2018-53310.

${ }^{53}$ Thea Enns, Luann Good Gingrich, and Kaylee Perez, "Religious Heritage, Institutionalized Ethos, and Synergies: Mennonite Central Committee and Canada's Private Sponsorship of Refugees Program," in Strangers to Neighbours: Refugee Sponsorship in Context, ed. Shauna Labman and Geoffrey Cameron (Montreal: McGill-Queen's University Press, forthcoming 2020).

${ }^{54}$ Government of Canada, "Canada: A History of Refuge," Government of Canada, last modified January 16, 2020, https://www.canada.ca/en/immigration-refugees-citizenship/services/refugees/canadarole/timeline.html.

${ }^{55}$ Geoffrey Cameron, "Reluctant Partnership: A Political History of Private Sponsorship in Canada (19471980)," in Strangers to Neighbours: Refugee Sponsorship in Context, ed. Shauna Labman and Geoffrey Cameron (Montreal: McGill-Queen's University Press, forthcoming 2020).

${ }^{56}$ Ibid.
} 
The late 1960s and 70s marked a turning point in Canada's approach to immigration and refugees. In 1967, Canada adopted the points system, which removed race and nationality as official criteria for immigrant selection. ${ }^{57}$ In 1969, Canada signed the 1951 UN Convention relating to the Status of Refugees and the 1967 Protocol, committing Canada to international obligations in terms of refugee protection. ${ }^{58}$ In 1971, the government adopted a policy of multiculturalism. ${ }^{59}$ In 1976, Canada passed the Immigration Act, which aimed "to fulfill Canada's international legal obligations with respect to refugees and to uphold its humanitarian tradition with respect to the displaced and the persecuted." ${ }^{60}$ It enabled the government to introduce regulations for the sponsorship of refugees by individuals or organizations. ${ }^{61}$

Mennonite Central Committee was the first organization to sign a sponsorship agreement with the government in 1979, and other religious organizations followed later that year. ${ }^{62}$ Although SAHs now include non-religious organizations, sponsorship still relies extensively on the infrastructure of religious organizations. Of the $106 \mathrm{SAHs}$ who received spaces to sponsor refugees under the PSR program in 2018, 79 of them were religious organizations, and they received $72 \%$ of the spaces $(5,480$ spaces $) .{ }^{63}$

\footnotetext{
${ }^{57}$ Kelley and Trebilcock, The Making of the Mosaic.

${ }^{58}$ United Nations High Commissioner for Refugees, "States Parties to the 1951 Convention and Its 1967 Protocol," April 2015, https://www.unhcr.org/protection/basic/3b73b0d63/states-parties-1951-conventionits-1967-protocol.html.

${ }^{59}$ Evaluation Division, "Evaluation of the Host Program," 18.

${ }^{60}$ Government of Canada, "Immigration Act," C.52 (1976), accessed January 31, 2020, sec. 3, https://pier21.ca/research/immigration-history/immigration-act-1976.

${ }^{61}$ Government of Canada, "Immigration Act," sec. 115(1)(k.1).

${ }^{62}$ William Janzen, “The 1979 MCC Canada Master Agreement for the Sponsorship of Refugees in Historical Perspective,” Journal of Mennonite Studies, no. 24 (2006): 211-22.

${ }^{63}$ Calculated by the author based on IRCC, "Memorandum to the Minister: 2018 Sponsorship Agreement Holder Allocation Figures," February 21, 2018, F-978154, obtained under an Access to Information request, A-2018-07384.
} 


\subsection{Indochinese Resettlement and the Launch of Private Sponsorship}

The Indochinese resettlement initiative officially launched the private sponsorship program. After the Communist victory in the Vietnam War, over 60,000 Indochinese "Boat People" refugees were resettled in Canada in 1979 and $1980 .{ }^{64}$ Of those refugees, 34,000 were privately sponsored by 7,000 sponsorship groups across Canada ${ }^{65}$ In 1986, the UNHCR awarded its Nansen Refugee Award for service to refugees to "the people of Canada" for their work in welcoming Indochinese refugees. ${ }^{66}$ Many authors have documented the experience of the Indochinese initiative and its continued impact on Canadian resettlement policy. ${ }^{67}$

\subsection{Settlement Services: From the Government to NGOs and Volunteers}

In the early 1980s, settlement support for GARs was delivered directly by the government through civil servants in major cities. ${ }^{68}$ In 1985 , the government invested money in NGOs, making local community organizations into settlement Service-Providing Organizations (SPOs). ${ }^{69}$ In 1998, the government introduced the current Resettlement Assistance Program, which shifted services for GARs from the government to provision by local

\footnotetext{
${ }^{64}$ Government of Canada, "Canada: A History of Refuge."

${ }^{65}$ IRCC, "By the Numbers."

${ }^{66}$ Canadian Immigration Historical Society, "Presentation: (1986) UNHCR Nansen Refugee Award to the people of Canada," Canadian Immigration Historical Society, February 18, 2014, http://cihs-shic.ca/unhcrnansen-refugee-award/.

${ }^{67}$ See for example Michael Molloy et al., Running on Empty: Canada and the Indochinese Refugees, 1975 1980, McGill-Queen's Studies in Ethnic History 41 (Montreal: McGill-Queen's University Press, 2017); Michael Molloy and James Simeon, “The Indochinese Refugee Movement and the Launch of Canada's Private Sponsorship Program," Refuge: Canada's Journal on Refugees 32, no. 2 (July 2016): 3-8; Michael Casasola, "The Indochinese Refugee Movement and the Subsequent Evolution of UNHCR and Canadian Resettlement Selection Policies and Practices," Refuge: Canada's Journal on Refugees 32, no. 2 (July 2016): 41-53; Barbara Treviranus and Michael Casasola, "Canada's Private Sponsorship of Refugees Program: A Practitioners Perspective of Its Past and Future," Journal of International Migration and Integration 4, no. 2 (December 2003): 177-202, http://dx.doi.org/10.1007/s12134-003-1032-0.

${ }^{68}$ Enns, "The Opportunity to Welcome," 25.

69 Ibid.
} 
SPOs. ${ }^{70}$ As of November 2018, there were 37 NGOs across Canada delivering RAP services to GARs, located in 35 communities across Canada. ${ }^{71}$ IRCC suggests that the settlement services model "can be characterised as a public-private partnership" and noted that "benefits of this type of model are that it reduces the size of government administration and allows the federal government to promote consistency of service delivery while still allowing for delivery flexibility based on needs determined at the local level." 72

Around the same time, volunteers also became increasingly involved in refugee resettlement. The Host Program pilot which began in 1984, "matched newly-arrived refugees with individuals or families, who then assisted their 'friends' to cope with all of the challenges of moving to a new country." 73 The program was made permanent and extended to other newcomer groups in 1990, and it was replaced by the Community Connections program in $2008 .{ }^{74}$ In 2010, it was noted that the Host Program was "the only program, except the Privately Sponsored Refugees Program, that involves Canadians directly in the delivery of services to newcomers." ${ }^{, 75}$ The Host Program made almost 24,000 matches between 2004 and 2008, with most matches lasting 8-9 months, and volunteers and newcomers meeting about three times per month. ${ }^{76}$ The government's evaluation of the program suggested that an "important element of a volunteer-run program is the ability

\footnotetext{
${ }^{70}$ Evaluation Division, "Evaluation of Government Assisted Refugees (GAR) and Resettlement Assistance Program (RAP)" (Ottawa: Citizenship and Immigration Canada, 2011), 2, http://publications.gc.ca/collections/collection_2012/cic/Ci4-69-2011-eng.pdf.

${ }^{71}$ IRCC, "Find Help to Adjust - Refugees," Government of Canada, last modified November 13, 2018, https://www.canada.ca/en/immigration-refugees-citizenship/services/refugees/help-withincanada/government-assisted-refugee-program/providers.html.

${ }^{72}$ Evaluation Division, "Evaluation of the Settlement Program," 20.

${ }^{73}$ Evaluation Division, "Evaluation of the Host Program," 7.

${ }^{74}$ Ibid., ix, 7.

${ }^{75}$ Ibid., 17.

${ }^{76}$ Ibid., 33.
} 
to leverage unpaid resources."77 It is estimated that volunteers contributed 125,612 volunteer hours to the program in $2007 / 08 .^{78}$

Several scholars have reflected on these changes. Enns describes processes of decentralization and privatization, with responsibility and ownership transferring to local NGOs. ${ }^{79}$ Drawing on Foucault and governmentality, Lippert sees the transition of settlement services to NGOs, the rise of private sponsorship, and the emergence of volunteer matching programs for GARs as characteristic of an "advanced liberal rationality" involving privatization, localization and responsibility-shifting. ${ }^{80}$ Türegün notes that the Canadian state is responsible for defining programming and providing funding, but delegates delivery of services to government-funded immigrant settlement agencies, which in practice are "sites of jurisdiction shared by settlement workers, social workers, paraprofessionals, and volunteers." ${ }^{81}$ Behnia writes about the challenges for organizations in recruiting volunteers for befriending or matching programs for refugees, ${ }^{82}$ as well as the motivations and experiences of Canadian-born and immigrant volunteers who are matched with newcomers. ${ }^{83}$

\footnotetext{
${ }^{77}$ Evaluation Division, "Evaluation of the Host Program," 46.

78 Ibid.

${ }^{79}$ Enns, "The Opportunity to Welcome," 25-26.

${ }^{80}$ Randy Lippert, "Rationalities and Refugee Resettlement," Economy and Society 27, no. 4 (1998): 380406, https://doi.org/10.1080/03085149800000026.

${ }^{81}$ Adnan Türegün, "Immigrant Settlement Work in Canada: Limits and Possibilities for Professionalization,” Canadian Review of Sociology 50, no. 4 (November 2013): 397, https://doi.org/10.1111/cars.12025.

82 Behnam Behnia, “An Exploratory Study of Befriending Programs with Refugees," Journal of Immigrant \& Refugee Studies 5, no. 3 (September 2007): 1-19, https://doi.org/10.1300/J500v05n03_01.

${ }^{83}$ Behnam Behnia, "Volunteering with Newcomers: The Perspectives of Canadian- and Foreign-Born Volunteers," Canadian Journal of Nonprofit and Social Economy Research 3, no. 2 (Autumn 2012): 6-23.
} 


\subsection{Government Funding, Sponsor Care: A History of Blended Programs}

A variety of blended programs have combined government financial support and sponsor care. Historically, "Canadian resettlement forms used by agencies in Europe in the 1970s gave three resettlement options, which essentially equate to government, private, or shared. The conceptual basis for Canadian resettlement thus began with refugees coming through public, private, or shared public-private responsibility." 84 The Joint Assistance Sponsorship program launched at the same time as private sponsorship. The original sponsorship agreements incorporated an understanding of JAS:

the individual sponsoring groups provide day-to-day hands-on care...the Department would provide an overall structure that included language training and allowances and a willingness to take over from the sponsors any cases that were exceptionally costly or requiring unusual professional services...for many of the more difficult families a mix of Departmental money and hands-on care provided by sponsors became the norm. ${ }^{85}$

It appears that originally, PSR cases with high needs could sometimes become JAS cases. Although JAS has been used since 1979 for individual cases, the 1999 emergency airlift of more than 5,000 Kosovar refugees to Canada made widespread use of the program by designating the entire population as "high needs." 86 After spending about two months on Canadian military bases, the Kosovars joined JAS sponsors across Canada.

In addition to JAS, various blended funding initiatives have combined government and sponsor funding, with cost-sharing models such as three months of government financial support followed by nine months of sponsor financial support. These initiatives

\footnotetext{
${ }^{84}$ Labman, Crossing Law's Border, 2019, 85.

${ }^{85}$ Molloy et al., Running on Empty, 76.

${ }^{86}$ Tracey M. Derwing and Marlene Mulder, "The Kosovar Sponsoring Experience in Northern Alberta," Journal of International Migration and Integration 4, no. 2 (December 1, 2003): 218, https://doi.org/10.1007/s12134-003-1034-y.
} 
have included Project FOCUS Afghanistan, sponsoring 1,800 Afghan Ismaili refugees between 1994 and $1998,{ }^{87}$ the 1995 " $3 / 9$ Programme" that resulted in the sponsorship of 477 refugees from the former Yugoslavia, ${ }^{88}$ and a program for refugees from Sierra Leone. ${ }^{89}$ A 2011 partnership with Rainbow Refugee was repeatedly renewed and is now a permanent program for 50 LGBTQ+ refugees per year. ${ }^{90}$ The government has also negotiated blended programs with specific sponsoring organizations, including the Anglican Church in $2009^{91}$ and the Armenian Community Centre of Toronto in 2011.92

The current BVOR program was introduced in 2013 after the 2012 Budget converted one thousand GAR spaces to BVOR spaces. ${ }^{93}$ The government explained that "as part of the Economic Action Plan 2012, the ratio of GARs and PSRs is being adjusted... up to 1,000 refugees identified by the UNHCR and selected for resettlement in Canada will be matched with interested private sponsors by 2015."94 It was understood as "a unique public-private partnership that encourages faith-based, ethnocultural and other

\footnotetext{
${ }^{87}$ Labman, Crossing Law's Border, 2019, 98.

${ }^{88}$ Jamieson, Beals, Lalonde \& Associates, "Evaluation of the 3/9 Refugee Sponsorship Programme Final Report" (Ottawa, July 1996), i, 15, Canadian Official Publications, Library and Archives Canada.

${ }^{89}$ Labman, Crossing Law's Border, 2019, 106.

${ }^{90}$ IRCC, "Canada Announces New Initiative to Support LGBTQ2 Refugees," Government of Canada News Releases, June 1, 2019, https://www.canada.ca/en/immigration-refugees-citizenship/news/2019/06/canadaannounces-new-initiative-to-support-lgbtq2-refugees.html.

${ }^{91}$ Citizenship and Immigration Canada, "Government of Canada and the Anglican Church of Canada Encourage Canadians to Sponsor Refugees," Government of Canada News Release, April 16, 2009, https:/www.canada.ca/en/news/archive/2009/04/government-canada-anglican-church-canada-encouragecanadians-sponsor-refugees.html; Citizenship and Immigration Canada, "Canada and Anglican Church Give 50 Refugee Families New Hope," Government of Canada News Releases, February 9, 2012 , https:/www.canada.ca/en/news/archive/2012/02/canada-anglican-church-give-50-refugee-families-newhope.html; Labman, Crossing Law's Border, 2019, 99.

92 Citizenship and Immigration Canada, "Canada's Commitment to Iraqi Refugees Remains Strong," Government of Canada News Releases, March 18, 2011, https:/www.canada.ca/en/news/archive/2011/03/canada-commitment-iraqi-refugees-remains-strong.html. ${ }^{93}$ Citizenship and Immigration Canada, "2011-2012 Departmental Performance Report” (Ottawa: Citizenship and Immigration Canada, 2012), 32.

94 Citizenship and Immigration Canada, "2012-2013 Departmental Performance Report” (Ottawa: Citizenship and Immigration Canada, 2013), https://www.canada.ca/en/immigration-refugeescitizenship/corporate/publications-manuals/departmental-performance-reports/2013.html.
} 
community organizations in Canada to play a larger role in offering durable solutions to refugees found to be in need of resettlement by the UNHCR or other referral agencies, supporting the objectives of both the GAR and Private Sponsorship of Refugees programs." $" 95$ There was limited uptake among sponsors in the first two years of the program, and only 313 refugees were resettled in 2013 and $2014 .^{96}$

The BVOR program quickly faced criticism from scholars and refugee advocates for privatizing resettlement responsibility. ${ }^{97}$ The Canadian Council for Refugees asserted that "Canadians who stepped up to sponsor BVORs were not adding to the number of refugees resettled: they were rather saving the government money" and the program risked "simply substituting and subsidizing the government commitment." ${ }^{98}$ However, if BVOR is compared to the Visa Office-Referred program, in which sponsors are required to fundraise $100 \%$ of the money, it can instead be seen as offering a financial incentive for people to sponsor government-selected refugees. ${ }^{99}$

Many of the tensions within the current BVOR program were already evident more than 15 years earlier in the evaluation of the 1995 "3/9 Programme" for refugees from the former Yugoslavia. One of the reasons it was considered successful was that "by combining public and private resources more refugees were settled than would have been

\footnotetext{
95 Minister of Citizenship and Immigration, "Report on Plans and Priorities 2014-2015" (Ottawa: Citizenship and Immigration Canada, 2014), 37, https://www.canada.ca/content/dam/ircc/migration/ircc/english/pdf/pub/rpp-2014-2015.pdf.

${ }^{96}$ Evaluation Division, "Evaluation of the Resettlement Programs," 3.

${ }^{97}$ Labman and Pearlman, "Blending, Bargaining, and Burden-Sharing"; Labman, "Private Sponsorship"; Hyndman, Payne, and Jimenez, "The State of Private Refugee Sponsorship in Canada," 6; Jennifer Hyndman, "Unsettling Feminist Geopolitics: Forging Feminist Political Geographies of Violence and Displacement," Gender, Place \& Culture (2019): 1-27, https://doi.org/10.1080/0966369X.2018.1561427.

${ }^{98}$ Canadian Council for Refugees, "Statement on Blended Visa Office Referred Refugees," Canadian Council for Refugees, July 21, 2016, https://ccrweb.ca/en/BVOR-statement.

${ }^{99}$ Emilie Coyle (Former Director of National Programs, Refugee Hub), interview with author, December $16,2019$.
} 
possible with public funding alone." ${ }^{100}$ However, the evaluation noted "the continuing concerns which NGOs have regarding the government's 'true' intentions, i.e. is $3 / 9$ a means of reducing governmental expenditures as opposed to truly maximizing the settlement of refugees." ${ }^{\prime 101}$ Even within the evaluation, it is unclear whether the program involves sponsors supporting a government program, or whether it is "using government funds to encourage private sponsorship." ${ }^{102}$ These questions continue to cause tension in the BVOR program. In 2018 and 2019, to encourage BVOR sponsorship, philanthropists contributed to a fund to reduce the financial obligations of BVOR sponsors. ${ }^{103}$

One study that conducted interviews noted that "given the blurred boundaries between government and private assistance, refugees, sponsors, and settlement workers were at times not sure of the program under which their sponsorship occurred," particularly refugees arriving through the BVOR program who thought they were privately sponsored since sponsors were taking care of them. ${ }^{104}$ This finding highlights that the resettlement categories are more fluid in practice. Though the study retained "some philosophical and ideological concerns" about BVOR, it recommended the program "as possibly a better way forward - with both government and private sponsors helping refugees, each for a given

\footnotetext{
100 Jamieson, Beals, Lalonde \& Associates, "Evaluation of the 3/9 Refugee Sponsorship Programme Final Report," ii.

101 Ibid., 20.

102 Ibid., 3.

${ }^{103}$ Refugee Hub, "News Release: Hundreds of Refugees to Settle in Canada by Year's End after Receipt of \$3.5 Million in Donations Ensures Community Sponsorship Spaces Are Filled," The Refugee Hub, November 14, 2018, https://refugeehub.ca/news-release-hundreds-of-refugees-to-settle-in-canada-by-yearsend-after-receipt-of-3-5-million-in-donations-ensures-community-sponsorship-spaces-are-filled/; Refugee Hub, "PRESS RELEASE: Funds Now Available for Canadians to Sponsor Hundreds of Refugees in 2019," The Refugee Hub, May 2, 2019, https:/refugeehub.ca/press-release-funds-now-available-for-canadians-tosponsor-hundreds-of-refugees-in-2019/.

${ }^{104}$ Sandeep Kumar Agrawal, "Canadian Refugee Sponsorship Programs: Experience of Syrian Refugees in Alberta, Canada,” Journal of International Migration and Integration, (December 2018), https://doi.org/10.1007/s12134-018-0640-7.
} 
period of time" suggesting that a "composite approach could offset the deficits inherent in each single approach." 105

In the 35 years between the major Indochinese and Syrian initiatives, several other groups of refugees were sponsored to Canada in smaller numbers or over longer periods of time. ${ }^{106}$ In 2001, Parliament passed the new Immigration and Refugee Protection Act, which shifted refugee selection criteria to focus more on protection and away from the expectation to achieve self-sufficiency within one year. ${ }^{107}$ In 2012, IRCC introduced caps on the number of sponsorship applications SAHs could submit, in an effort to reduce a growing backlog of applications and reduce processing times. ${ }^{108}$ These caps have been controversial, with the Canadian Council for Refugees arguing that they should be eliminated altogether. ${ }^{109}$

\subsection{The Syrian Initiative}

Initial Canadian resettlement responses to the Syrian conflict were small and focused on private sponsorship. By January 2015, 1,100 Syrians had come to Canada, only 360 of whom were GARs. ${ }^{110}$ Following an election campaign in which Syrian refugees were a major issue - in part because of the iconic image of Alan Kurdi who drowned trying to reach Europe - in October 2015 the Liberals formed a majority government and acted

\footnotetext{
105 Agrawal, "Canadian Refugee Sponsorship Programs.”

106 IRCC, "By the Numbers."

${ }^{107}$ Citizenship and Immigration Canada, "Building on a Strong Foundation for the 21st Century: New Directions for Immigration and Refugee Policy and Legislation" (Citizenship and Immigration Canada, 1998), 41, 43, http://publications.gc.ca/collections/Collection/Ci51-86-1998E.pdf; Government of Canada, Immigration and Refugee Protection Act, sec. 3.

108 Citizenship and Immigration Canada, "2011-2012 Departmental Performance Report,” 32.

${ }^{109}$ Canadian Council for Refugees, "Renewing Canada's Private Sponsorship of Refugees Program" (Canadian Council for Refugees, January 13, 2016), https:/ccrweb.ca/sites/ccrweb.ca/files/renewing-psrjan-2016.pdf.

${ }_{110}$ Susana Mas, "Canada to Resettle 10,000 More Syrian Refugees over 3 Years," CBC News, January 7 , 2015, https:/www.cbc.ca/news/politics/canada-to-resettle-10-000-more-syrian-refugees-over-3-years1.2892652 .
} 
quickly on their campaign promise to resettle 25,000 Syrians. With the help of multiple departments, the government processed more refugees in three months than in all of 2013 and 2014 combined. ${ }^{111}$ By March 2016, Canada succeeded in welcoming 25,000 Syrians.

Initially the target was reached with help from private sponsors. Of the 26,172 Syrians who arrived between November 4, 2015 and March 1, 2016, only 57\% were GARs, while $34 \%$ were PSRs and $8 \%$ were BVORs. ${ }^{112}$ Commenting on the large number of Syrians who were in fact privately sponsored, Enns suggests:

election promises were not technically met by Trudeau; rather, civil society stepped in to fulfil the target and image of Trudeau's campaign. This bottom-up reality challenges the image and the role of national governments, and suggests that the integrity and responsibility of the 'welcoming' nation lies in the hands of private citizens. ${ }^{113}$

Sponsorship is part of broader ethical discourses of hospitality, inclusion, and diversity, which are "negotiated, embodied, and performed by the federal government and individual Canadians sponsoring refugees." ${ }^{114}$ By the beginning of 2017, over 40,000 Syrian refugees had arrived in Canada: 55\% GARs, $10 \%$ BVORs, and 36\% PSRs. ${ }^{115}$

\subsection{Post-Syrian Initiative: Yazidi Resettlement and Forty Years of Sponsorship}

On 25 October 2016, the House of Commons voted in response to political pressure from the opposition Conservatives to resettle 1200 vulnerable Yazidi women and children and

\footnotetext{
${ }^{111}$ Evaluation Division, "Evaluation of the Syrian Initiative," 34.

${ }^{112}$ Government of Canada, "\#WelcomeRefugees: The Journey to Canada," Government of Canada, last modified November 28, 2016, https://www.canada.ca/en/immigration-refugees-

citizenship/services/refugees/welcome-syrian-refugees/infographic.html.

${ }^{113}$ Enns, "The Opportunity to Welcome," 33.

${ }^{114}$ Anna Hutchinson, "Welcome to Canada': Hospitality, Inclusion and Diversity in Private Refugee Sponsorship," UCL Migration Research Unit Working Papers, no. 2 (2018).

${ }^{115}$ Government of Canada, "\#WelcomeRefugees: Key Figures," Government of Canada, last modified February 27, 2017, https://www.canada.ca/en/immigration-refugees-citizenship/services/refugees/welcomesyrian-refugees/key-figures.html.
} 
other survivors of Daesh (also known as ISIS). ${ }^{116}$ By July 2018, 1,400 survivors of Daesh had resettled as GARs. ${ }^{117}$ The Yazidis faced significant integration challenges such as severe mental health issues. As chapter 3 will explore, many cases were referred to the inCanada JAS program. Pearlman's detailed study of Operation Ezra in Winnipeg explains how it began as a private sponsorship group for Yazidi refugees and evolved into a broad coalition of volunteers and organizations supporting over 300 Yazidi GARs and PSRs. ${ }^{118}$ She writes that an approach serving the entire Yazidi community "has resulted in a reliance on private sponsors to step up and provide additional resettlement support and resources to other refugee groups, which contradicts what was meant to be the point of the multi-stream framework for refugee resettlement in Canada." "119 She expresses the concern "that private sponsor initiatives that attempt to address deficiencies in resettlement services risk reducing government accountability to resettled refugees generally, and to governmentassisted refugees in particular."120

Since the launch of the Global Refugee Sponsorship Initiative in 2016, Canada has been working to grow private sponsorship within Canada and overseas. Starting in 2017, IRCC began to increase monitoring of the private sponsorship program, a controversial initiative that will be discussed in chapter 4 . There is a growing effort by scholars and the

\footnotetext{
${ }^{116}$ IRCC, "Helping Vulnerable Yazidi Women and Children and Other Survivors of Daesh," Government of Canada, February 21, 2017, https://www.canada.ca/en/immigration-refugeescitizenship/news/2017/02/helping_vulnerableyazidiwomenandchildrenandothersurvivorsofdaesh.html. ${ }^{117}$ IRCC, "2017-2018 Departmental Results Report” (Ottawa: IRCC, 2018), https://www.canada.ca/en/immigration-refugees-citizenship/corporate/publications-manuals/departmentalperformance-reports/2018.html.

118 Madison Pearlman, “Operation Ezra: A New Way Forward," in Strangers to Neighbours: Refugee Sponsorship in Context, ed. Shauna Labman and Geoffrey Cameron (Montreal: McGill-Queen's University Press, forthcoming 2020).

119 Ibid.

120 Ibid.
} 
government to compare integration experiences and outcomes between PSRs, GARs, and BVORs - in part to test the common assertion that sponsored refugees "integrate better" than GARs - using quantitative and qualitative methods to examine employment, other economic outcomes, health, housing, social networks, and language acquisition. ${ }^{121}$ Overall, these studies have found benefits of sponsorship, but have also noted the challenges of comparing refugee categories given significant pre-arrival demographic differences (such as education levels and medical needs) due to different mechanisms for selection (UNHCR referral based on vulnerability criteria versus naming by sponsors).

In 2019, Canada celebrated 40 years since the launch of the private sponsorship program, noting that since 1979 , over 327,000 refugees have been privately sponsored. ${ }^{122}$ With targets of 20,000 PSRs per year from 2020-2022, Canada plans to welcome 60,000 PSRs over the next three years. ${ }^{123}$ These yearly targets are about four times the historic

\footnotetext{
${ }^{121}$ Evaluation Division, "Evaluation of the Syrian Initiative"; Lisa Kaida, Feng Hou, and Max Stick, "The Long-Term Economic Integration of Resettled Refugees in Canada: A Comparison of Privately Sponsored Refugees and Government-Assisted Refugees," Journal of Ethnic and Migration Studies 46, no. 9 (July 3 , 2020): 1687-1708, https://doi.org/10.1080/1369183X.2019.1623017; Sonja Senthanar et al., "Employment Integration Experiences of Syrian Refugee Women Arriving through Canada's Varied Refugee Protection Programmes," Journal of Ethnic and Migration Studies (March 2020): 1-21, https://doi.org/10.1080/1369183X.2020.1733945; Michaela Hynie et al., "What Role Does Type of Sponsorship Play in Early Integration Outcomes? Syrian Refugees Resettled in Six Canadian Cities," Refuge: Canada's Journal on Refugees 35, no. 2 (June 2019): 36-52; Anna Oda et al., "Differences in SelfReported Health and Unmet Health Needs Between Government Assisted and Privately Sponsored Syrian Refugees: A Cross-Sectional Survey," Journal of Immigrant and Minority Health 21, no. 3 (June 2019): 439-42, https://doi.org/10.1007/s10903-018-0780-z; Jack Jedwab, “GARs vs. PSRs: Explaining Differences in Outcomes for Recent Refugees to Canada," Canadian Diversity 15, no. 2 (January 2018); Julie Drolet and Gayatri Moorthi, "The Settlement Experiences of Syrian Newcomers in Alberta: Social Connections and Interactions," Canadian Ethnic Studies 50, no. 2 (August 13, 2018): 101-20, https://doi.org/10.1353/ces.2018.0017; Morton Beiser, "Sponsorship and Resettlement Success," Journal of International Migration and Integration 4, no. 2 (2003): 203-215, https://doi.org/10.1007/s12134-0031033-z.

${ }^{122}$ IRCC, "Canada Celebrates 40 Years of the Refugee Sponsorship Program," Government of Canada Newsroom, April 9, 2019, https://www.canada.ca/en/immigration-refugees-

citizenship/news/2019/04/canada-celebrates-40-years-of-the-refugee-sponsorship-program.html; IRCC, "By the Numbers."

${ }^{123}$ IRCC, "Notice - Supplementary Information 2020-2022 Immigration Levels Plan," Government of Canada, March 12, 2020, https://www.canada.ca/en/immigration-refugeescitizenship/news/notices/supplementary-immigration-levels-2020.html.
} 
PSR numbers, which from 2001 to 2014 were typically between 3,000 and 5,000 per year. ${ }^{124}$ Labman remarked that "more than ever before, the actions of private sponsors are being celebrated by the Canadian government under the rubric of its own humanitarianism." ${ }^{125}$ However, as this history and the next section on tensions within the program show, "Canadians would do well to admit that their experience has never been as harmonious as the one they present to international delegations." 126

\subsection{Privatization and Private Sponsorship}

There have been several recurring tensions in the history of private sponsorship in Canada, involving both pre-arrival issues and post-arrival supports. Cameron notes that "many contemporary issues related to private sponsorship have characterized the program since its inception" including "questions related to selection processes (who identifies, or 'names,' the refugees to be sponsored), selection criteria (whether humanitarian, economic, or strategic criteria should be applied), and financial responsibility (the distribution of costs and liabilities shared by sponsors and the state)." ${ }^{127}$ In terms of selection, PSR has largely played a role of family reunification and in many ways resembles family sponsorship, ${ }^{128}$ particularly since the cancellation of the Assisted Relatives immigration class in 2002 left refugees without a way to reunite with extended relatives like siblings. ${ }^{129}$ As a result, there

\footnotetext{
${ }^{124}$ Labman, Crossing Law's Border, 2019, 57.

125 Shauna Labman, Crossing Law's Border: Canada's Refugee Resettlement Program, Law and Society Series (Vancouver: UBC Press, 2019), 158.

${ }^{126}$ Craig Damian Smith, “A Model for the World? Policy Transfer Theory and the Challenges to 'Exporting' Private Sponsorship to Europe," in Strangers to Neighbours: Refugee Sponsorship in Context, ed. Shauna Labman and Geoffrey Cameron (Montreal: McGill-Queen's University Press, forthcoming 2020).

127 Cameron, "Reluctant Partnership: A Political History of Private Sponsorship in Canada (1947-1980)."

${ }^{128}$ Audrey Macklin et al., "Kindred Spirits? Links Between Refugee Sponsorship and Family Sponsorship," in Strangers to Neighbours: Refugee Sponsorship in Context, ed. Shauna Labman and Geoffrey Cameron (Montreal: McGill-Queen's University Press, forthcoming 2020).

${ }^{129}$ Canadian Council for Refugees, "Assisted Relatives," November 2004, https://ccrweb.ca/en/res/assisted-relatives.
} 
is tension between selection criteria based on family reunification versus protection or vulnerability, ${ }^{130}$ with several scholars arguing for a separate family reunification program for refugees. ${ }^{131}$ Other ongoing pre-arrival controversies include long processing times, unequal processing times by region, and the cap system which limits applications. ${ }^{132}$

This thesis focuses on post-arrival supports, where a narrative of privatization is a long-standing theme in historical accounts of private sponsorship, in current debates, and in the literature. As mentioned earlier, privatization has been applied to the introduction of the BVOR program and the transition of settlement services to local NGOs and volunteers. In the context of the PSR program, the privatization debate has focused on state responsibility, the shifting ratio of GARs to PSRs and financial responsibility. From the beginning, "the concern about private sponsorship in Canada has been the privatization of a responsibility that is considered to rest with the state as a whole."133

Resettlement is commonly understood as a state activity. The UNHCR statute sets out the organization's mandate to seek permanent solutions for refugees:

The [UNHCR] shall assume the function of providing international protection, under the auspices of the United Nations, to refugees who fall within the scope of the present Statute and of seeking permanent solutions for the problem of refugees by assisting Governments and, subject to the

\footnotetext{
${ }^{130}$ For an ethical argument that scarce resettlement spaces should be allocated based on vulnerability criteria, see Patti Tamara Lenard, "How Should We Think about Private Sponsorship of Refugees?," in Strangers to Neighbours: Refugee Sponsorship in Context, ed. Shauna Labman and Geoffrey Cameron (Montreal: McGill-Queen's University Press, forthcoming 2020). For reflections on the tension between protection and family reunification, see Sabine Lehr and Brian Dyck, "'Naming' Refugees in the Canadian Private Sponsorship of Refugees Program: Diverse Intentions and Consequences," in Strangers to Neighbours: Refugee Sponsorship in Context, ed. Shauna Labman and Geoffrey Cameron (Montreal: McGill-Queen's University Press, forthcoming 2020).

${ }^{131}$ Labman, Crossing Law's Border, 2019; Andrea Bradley, "Beyond Borders: Cosmopolitanism and Family Reunification for Refugees in Canada," International Journal of Refugee Law 22, no. 3 (2010): 379-403, https://doi.org/10.1093/ijrl/eeq025.

${ }^{132}$ Hyndman, "Unsettling Feminist Geopolitics"; Stephen Kaduuli, "Continuing Welcome: A Progress Report on a Half Welcome" (Ottawa: Citizens for Public Justice, June 2020), https://cpj.ca/wpcontent/uploads/2020/06/Continuing-Welcome.pdf.

${ }^{133}$ Labman, Crossing Law's Border, 2019, 118.
} 
approval of the Governments concerned, private organizations to facilitate the voluntary repatriation of such refugees, or their assimilation within new national communities (emphasis added). ${ }^{134}$

Resettlement is one form of "assimilation within new national communities." The statute sees governments as the actors to provide solutions for refugees but acknowledges that "private organizations" may facilitate assimilation "subject to the approval of the Governments concerned." In all cases, resettlement happens with the support of states. Similarly, in its guidance for prospective and current resettlement states, UNHCR writes:

At the core of any sustainable resettlement programme is the commitment of the State to offering refugees protection and a truly durable solution. All other elements of a sustainable resettlement programme flow from this commitment. Establishing a formal resettlement programme is a generous expression of a State's commitment to sharing the responsibility for addressing refugee situations with countries of first asylum. ${ }^{135}$

While UNHCR recognizes that "non-governmental partners" may be involved in "reception services and integration supports," ultimately the commitment to resettlement, and responsibility for it lies with the state. ${ }^{136}$ Labman notes that "the state has absolute discretion to resettle refugees or not. If refugees are resettled, it is the state's discretion to decide whom to resettle, from where, and how."137 Given the voluntary nature of resettlement, defining the scope of state responsibility is challenging since "there is no clear consensus on the basis of this responsibility, be it moral, humanitarian, or burden sharing and demonstrative of international solidarity." 138 The traditional view of resettlement

\footnotetext{
${ }^{134}$ UNHCR, "Statute of the Office of the United Nations High Commissioner for Refugees" (UNHCR, October 2010), sec. 1, https:/www.unhcr.org/protection/basic/3b66c39e1/statute-office-united-nationshigh-commissioner-refugees.html.

${ }^{135}$ UNHCR, “The Integration of Resettled Refugees: Essentials for Establishing a Resettlement Programme and Fundamentals for Sustainable Resettlement Programmes" (UNHCR, 2013), 11, https://www.unhcr.org/52a6d85b6.pdf.

${ }^{136}$ Ibid., 11.

${ }^{137}$ Labman, Crossing Law's Border, 2019, 77.

138 Ibid., 118.
} 
revolves around the actions, commitments and responsibilities of states. The extent to which resettlement is considered a state activity is connected to broader ideas about the distribution of care and the role of the state. A comparative study found that in welfare state models such as Sweden, states provide more extensive public services to refugees, whereas in the United States, where public services are limited, resettlement relies extensively on private organizations. ${ }^{139}$

Many critics accusing the government of shifting responsibility have focused on the numbers, specifically the ratio of GARs to PSRs. ${ }^{140}$ The guiding principle for this ratio is known as "additionality," which according to the Canadian Council for Refugees means that "Canadians want to know that their government is fulfilling its responsibility, on behalf of all Canadians, to protect refugees through resettlement, and that any refugees they sponsor are additional to those resettled by the government" (emphasis in original). ${ }^{141}$ Scholars and activists have also asserted that "government resettlement numbers should always be higher than the numbers resettled by civil society."142 Figure 1 shows the breakdown of refugees resettled to Canada in the last 10 years, and demonstrates the changing ratio of GARs to PSRs.

\footnotetext{
139 Joanne van Selm, "Public-Private Partnerships in Refugee Resettlement: Europe and the US," Journal of International Migration and Integration 4, no. 2 (December 2003): 157-75, https://doi.org/10.1007/s12134-003-1031-1.

${ }^{140}$ Labman, "Private Sponsorship," 70; Labman and Pearlman, "Blending, Bargaining, and BurdenSharing," 443.

${ }^{141}$ Canadian Council for Refugees, "Renewing Canada's Private Sponsorship of Refugees Program."

${ }^{142}$ Canadian Council for Refugees, "2017 Immigration Levels - Comments"; Labman and Pearlman, "Blending, Bargaining, and Burden-Sharing," 443; Labman, "Private Sponsorship," 70; Hyndman, Payne, and Jimenez, "The State of Private Refugee Sponsorship in Canada," 3.
} 
Figure 1 Number of resettled refugees by program, 2009-2019 ${ }^{143}$

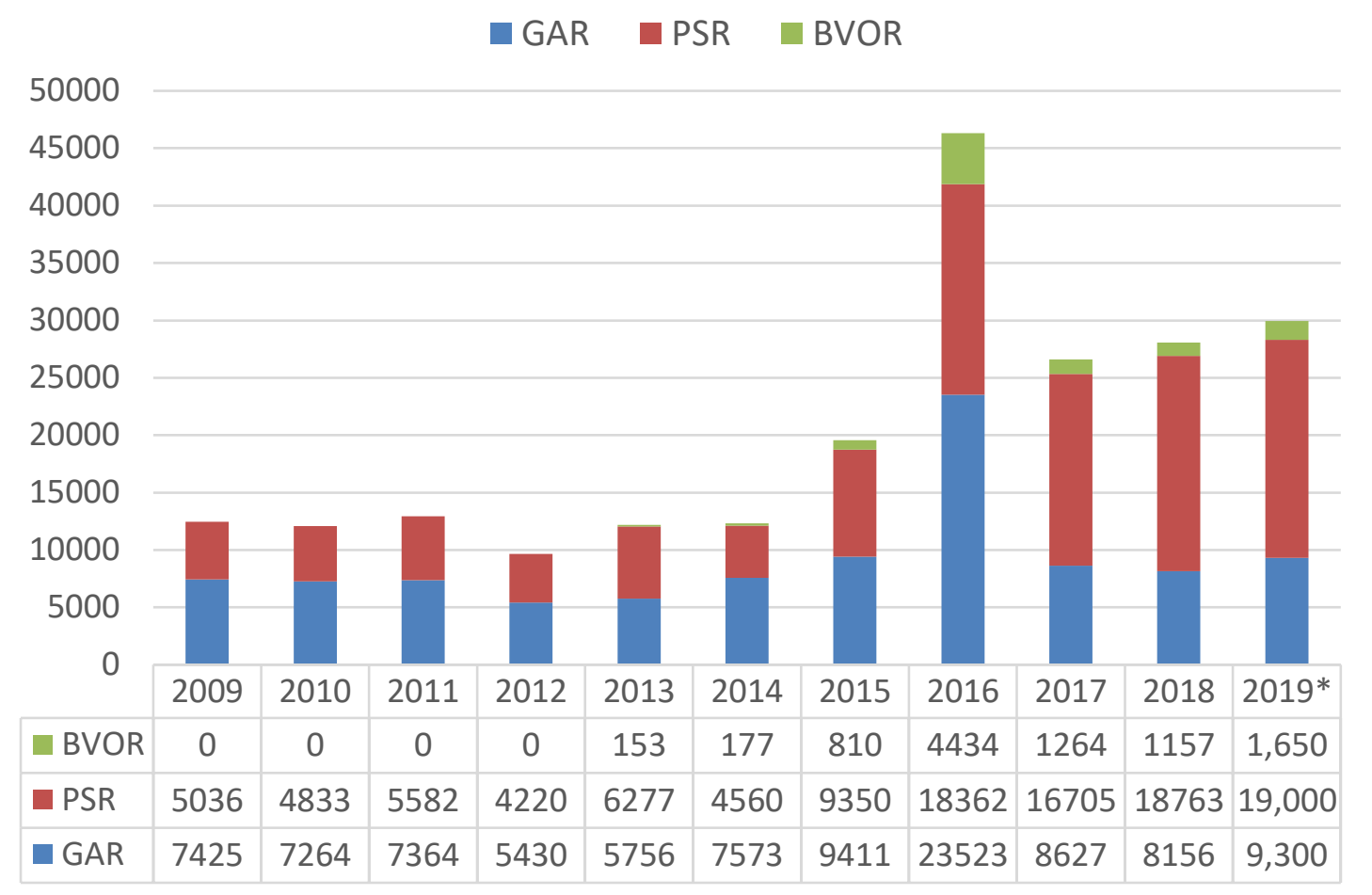

When targets for PSRs have exceeded targets for GARs, refugee advocates have accused the government of privatizing its commitment. ${ }^{144}$ However, the government interprets additionality differently, agreeing that PSR enables Canadians to "offer protection space over and above what is provided directly by the government" but suggesting that it is not necessary for the GAR numbers to be equal or higher. ${ }^{145}$ Recently, the government has

\footnotetext{
143 The UNHCR 2019 Global Trends Report reports 30,100 resettled refugees in Canada in 2019, which is slightly higher than the overall target of 29,950. As the final breakdown between programs is not yet available, the targets for each program are used, keeping in mind that it is very unlikely that the BVOR target was reached. Compiled by the author from the Refugee Sponsorship Training Bulletin, November 2, 2018; IRCC, "Notice - Supplementary Information 2019-2021 Immigration Levels Plan," Government of Canada, October 31, 2018, https://www.canada.ca/en/immigration-refugees-

citizenship/news/notices/supplementary-immigration-levels-2019.html; UNHCR, "Global Trends: Forced Displacement in 2019," 52.

${ }^{144}$ Canadian Council for Refugees, "2017 Immigration Levels - Comments."

${ }^{145}$ Evaluation Division, "Evaluation of the Resettlement Programs," 2.
} 
argued it is increasing PSR numbers "to respond to Canadians' generosity" and "to meet the demand of Canadians wishing to sponsor refugees." $" 146$

Although this thesis focuses primarily on settlement support, there have been several controversies surrounding financial support for all streams of refugees. The RAP income support, which is based on social assistance rates, has been critiqued (including by several government evaluations) for being inadequate, not responsive to refugees' needs, and insufficient to afford housing. ${ }^{147}$ Noting that sponsors are expected to provide financial support to refugees equivalent to local social assistance rates, Labman suggests that "the sponsor essentially takes on the state's responsibility for social welfare." 148 Legally, if a privately sponsored refugee receives social assistance from the government in their first year in Canada, the sponsor may be required to pay back the government. ${ }^{149}$ Moreover, refugees may be issued a travel loan of up to $\$ 10,000$ per family, repayable to the government, to cover the costs of travel and fees to the International Organization for Migration for organizing travel (\$240 per person). ${ }^{150}$ An evaluation of travel loans found that over half of recipients said that paying back the loan made it difficult to pay for basic

\footnotetext{
${ }^{146}$ Minister of IRCC, “Departmental Plan 2019-2020,” 1, 13-14.

${ }^{147}$ Evaluation Division, "Evaluation of GAR and RAP"; Evaluation Division, "Evaluation of the Resettlement Programs."

${ }^{148}$ Labman, Crossing Law's Border, 82.

149 IRCC, "Guide to the Private Sponsorship of Refugees Program," Government of Canada, last modified January 14, 2019, https:/www.canada.ca/en/immigration-refugees-citizenship/corporate/publicationsmanuals/guide-private-sponsorship-refugees-program.html.

${ }^{150}$ RSTP Bulletins, January 13, 2017 and July 14, 2017.
} 
necessities like food and housing. ${ }^{151}$ The Canadian Council for Refugees has argued since 2008 that the government should eliminate travel loans for refugees and absorb the cost. ${ }^{152}$

There is an ongoing debate in the literature about the extent to which privatization is problematic, especially drawing on neoliberalism and ethics. On the one hand, some have critiqued the idea of private sponsorship, as it can allow countries to privatize humanitarian obligations and leave individual citizens and civil society responsible for the number of admissions. ${ }^{153}$ Reflecting on the ethics of sponsorship, Lenard argues that while it may resettle more refugees in a cost-effective manner and encourage citizen involvement, sponsoring groups may not always have the cultural sensitivity or capacity necessary to support refugees, and governments may prioritize saving costs and shifting responsibilities rather than partnership. ${ }^{154}$ In the context of Canada promoting sponsorship overseas, Smith points out that while "European politicians like the fact that the Canadian model can shift costs onto private citizens" it "remains questionable whether privatizing international protection is a trend that Canada ought to promote" as it risks "displacing state-based international responsibility as envisaged in the 1951 Convention." 155

\footnotetext{
${ }^{151}$ IRCC, "Evaluation of the Immigration Loan Program" (Ottawa: IRCC, December 14, 2015), 40, https://www.canada.ca/en/immigration-refugees-citizenship/corporate/reportsstatistics/evaluations/immigration-loan-program.html.

${ }^{152}$ Canadian Council for Refugees, "Comments on Proposed Changes to the Transportation Loan" (Canadian Council for Refugees, October 2017), https://ccrweb.ca/sites/ccrweb.ca/files/transportationloans-comments.pdf.

${ }^{153}$ Catherine Dauvergne, Humanitarianism, Identity, and Nation: Migration Laws in Canada and Australia (Vancouver: UBC Press, 2005), 93.

${ }^{154}$ Patti Tamara Lenard, "Resettling Refugees: Is Private Sponsorship a Just Way Forward?," Journal of Global Ethics 12, no. 3 (September 2016): 300-310, https://doi.org/10.1080/17449626.2016.1247290.

${ }^{155}$ Craig Damian Smith, "A Model for the World? Policy Transfer Theory and the Challenges to 'Exporting' Private Sponsorship to Europe," in Strangers to Neighbours: Refugee Sponsorship in Context, ed. Shauna Labman and Geoffrey Cameron (Montreal: McGill-Queen's University Press, forthcoming 2020).
} 
Ritchie argues that "private resettlement must be understood as a class project that mobilises narratives of humanitarianism to advance neoliberal ideals of a lean state removed from social reproduction." 156 She suggests that "the involvement of various cultural, ethnic, and religious communities sanctions the apolitical appearance of private sponsorship, while simultaneously facilitating the deeply political (neoliberal) project of removing the state from functions of social welfare." ${ }^{157}$ She further argues that PSR "deploys a narrative of grassroots community action to conceal the ways in which Canada is a racially divided economy and society." ${ }^{" 158}$

Examining access to housing for GARs and PSRs, Silvius argues that "refugee well-being is increasingly becoming 'neo-liberalized', or made a 'private' affair predicated on market processes" and "obligations to refugees are increasingly being met by ethnocultural communities, religious groups, refugee kinship networks, and community-based organizations." $159 \mathrm{He}$ suggests that a "marketized refugee" with housing as a private responsibility "represents a profound departure from a paradigm in which the social care of/for refugees is a collective, and, presumably, national social responsibility." ${ }^{160}$

Enns in her study of the Syrian initiative draws on "responsibilization" as a form of neoliberal governance in Canadian social service delivery. ${ }^{161}$ She argues that "a rhetoric

\footnotetext{
${ }^{156}$ Genevieve Ritchie, "Civil Society, the State, and Private Sponsorship: The Political Economy of Refugee Resettlement," International Journal of Lifelong Education 37, no. 6 (November 2018): 672, https://doi.org/10.1080/02601370.2018.1513429.

157 Ibid., 671.

158 Ibid., 663.

${ }^{159}$ Ray Silvius, "Neo-Liberalization, Devolution, and Refugee Well-Being: A Case Study in Winnipeg, Manitoba," Canadian Ethnic Studies 48, no. 3 (2016): 27, https://doi.org/10.1353/ces.2016.0024.

160 Ibid., 32.

${ }^{161}$ Enns, "The Opportunity to Welcome"; Suzan Ilcan and Tanya Basok, "Community Government: Voluntary Agencies, Social Justice, and the Responsibilization of Citizens," Citizenship Studies 8, no. 2 (June 2004): 129-44, https://doi.org/10.1080/1362102042000214714.
} 
of 'welcome' works alongside neoliberal processes of privatisation and decentralisation [allowing] the national government to determine the extent of protection offered, while downloading the responsibility." 162 In practice, "local actors - RAP agencies, municipal governments, and community members have increasingly been the official providers of services, and the unofficial social and fiscal safety nets that cover the gaps within the system." 163 During the Syrian initiative, "local actors were overwhelmed with the responsibilities of reception and the long-term needs of resettlement, and had to collaborate and contribute to satisfy the gaps within the system" while "the individual level saw private sponsorship increasingly taking the lead on sustaining resettlement efforts." ${ }^{164}$ Overall, she argues that "decisions, determinations and destinations are made by the federal government, then outsourced to communities to carry out the tasks." ${ }^{165}$ Similarly, Tyyskä and colleagues highlight how neoliberalism, along with postcolonialism and orientalism, shaped media coverage of Syrian resettlement in Canada by emphasizing the importance of private citizens and the private sector in the Syrian resettlement initiative. ${ }^{166}$

On the other hand, a few have questioned whether privatization is problematic. Drawing on Derrida's idea of "unconditional hospitality," Kirvenko argues that "individuals can be the bearers of another sovereignty, distinct from that of states, and can implement international obligations in the area of refugee and human rights law more

\footnotetext{
162 Enns, "The Opportunity to Welcome," 8.

163 Ibid., 52.

164 Ibid., 31-32.

165 Ibid., 52.

166 Vappu Tyyskä et al., "Canadian Media Coverage of the Syrian Refugee Crisis: Representation, Response, and Resettlement," Geopolitics, History and International Relations 10, no. 1 (2018): 154, https://doi.org/10.22381/GHIR10120187.
} 
efficiently." 167 In this view, private sponsorship should be considered "more than just an interesting way to implement states' obligations" but actually "an example of, and opportunity for, innovative development in international law." 168

Despite accusations of privatization, more recent literature questions the extent to which a narrative of privatization accurately reflects government involvement and the importance of public services for sponsored refugees. Labman describes an interdependent relationship between the government and sponsors saying that "sponsors rely on the government to facilitate their sponsorships as much as the government relies on sponsors to contribute to Canada's humanitarian commitments." 169 As the entity responsible for establishing the program and processing refugees, the government "regulates numbers of privately sponsored refugees through annual levels, governs the criteria for sponsorship, screens nominated refugees against the refugee definition, conducts medical, criminality and security checks, and organizes refugees' transport to Canada." 170 Instead of contrasting "public" resettlement versus "private" sponsorship, a more accurate approach would be "to describe private sponsorship as akin to a publicprivate partnership, where the private partner is not a profit-seeking corporate entity, but rather an other-regarding collective formed for the specific purposes of refugee sponsorship." ${ }^{171}$ Similarly, Labman concludes:

privatization of resettlement through private sponsorship fails to encompass the broad reach of peripheral program supports by both government and

\footnotetext{
167 "Hospitality and Sovereignty: What Can We Learn From the Canadian Private Sponsorship of Refugees Program?," International Journal Of Refugee Law 24, no. 3 (2012): 579, https://doi.org/10.1093/ijrl/ees039.

168 Ibid., 579.

${ }^{169}$ Labman, "Private Sponsorship," 68.

${ }^{170}$ Audrey Macklin et al., "A Preliminary Investigation into Private Refugee Sponsors," Canadian Ethnic Studies 50, no. 2 (August 13, 2018): 41, https://doi.org/10.1353/ces.2018.0014.

171 Ibid., 39.
} 
other organizations; it also fails to acknowledge the wider community reach of many sponsorships. In many respects, private sponsorship is not private at all. It is a responsibility-sharing arrangement between institutions, groups of citizens, and the state. ${ }^{172}$

Within the private sponsorship program, sponsored refugees continue to have access to a broad range of government-funded services and settlement supports. As some scholars have noted: "an unspoken but major reason that private refugee resettlement happens in Canada is because various levels of government are willing to pay for education, health, and social services on par with those of citizens." ${ }^{\prime 13}$ European politicians have responded to the work of the Global Refugee Sponsorship Initiative by pointing out these kinds of costs that would have to be absorbed by the government. ${ }^{174}$ In addition, the government absorbs all costs related to processing (besides loans for medical exams and travel), which stands in contrast to Australia's program where sponsors pay high visa and processing fees and which is explicitly promoted by Australia's government as a revenue-generating project. ${ }^{175}$ Moreover, other supports such as the government-funded Refugee Sponsorship Training Program provide additional assistance to sponsors.

One policy brief that explores the feasibility of sponsorship for other countries concluded that "using volunteers and sponsors to facilitate refugee resettlement is not a cost-free or even necessarily a cost-saving endeavor; it requires targeted investment and

\footnotetext{
172 Shauna Labman, “Conclusion: Sponsorship's Success and Sustainability?," in Strangers to Neighbours: Refugee Sponsorship in Context, ed. Shauna Labman and Geoffrey Cameron (Montreal: McGill-Queen's University Press, forthcoming 2020).

${ }^{173}$ Hyndman, Payne, and Jimenez, "The State of Private Refugee Sponsorship in Canada,” 12.

174 Smith, "A Model for the World?"

175 Anthea Vogl, Khanh Hoang, and Asher Hirsch, "Private Humanitarian Sponsorship: Searching for the Community in Australia's Community Refugee Sponsorship Program," in Strangers to Neighbours:

Refugee Sponsorship in Context, ed. Shauna Labman and Geoffrey Cameron (Montreal: McGill-Queen's University Press, forthcoming 2020).
} 
sustained support." ${ }^{176}$ While volunteers and sponsors can play a complementary role to specialized settlement and social service agencies, adequate support and training is essential, including funded volunteer/sponsor coordinator positions. ${ }^{177}$ Another study highlighted that "PSRs also require settlement services; they cannot be left entirely to the resources (or lack thereof) of private sponsors." ${ }^{178}$

\subsection{Conclusion}

This chapter has presented an overview of the history of resettlement in Canada. Although resettlement and sponsorship have been taking place in Canada in various forms for more than 40 years, some historical moments have brought it to the forefront, especially the Indochinese initiative of 1979, the Syrian initiative of 2015-2016, and the subsequent celebration of 40 years of private sponsorship along with Canada's efforts to promote sponsorship to the world. Privatization and the distribution of responsibilities between public and private actors have been contentious issues since the beginnings of sponsorship in Canada, and especially since the introduction of the BVOR program and changes in targets that have led to a greater number of sponsored versus Government-Assisted Refugees. The privatization debate has largely focused on numbers and finances with less attention paid to care or settlement support. The next chapter explores how the concept of care can be a helpful lens to analyze the relationships within Canada's resettlement system.

\footnotetext{
176 Fratzke, "Volunteers and Sponsors," 13.

${ }^{177}$ Fratzke, "Volunteers and Sponsors."

178 Agrawal, "Canadian Refugee Sponsorship Programs."
} 


\section{Chapter 2: Care and Resettlement: Making Care Visible}

This chapter presents care as an analytical lens. First, it shows how feminist scholarship has disrupted the dichotomy between public and private. Second, it presents the moral ontology of care ethics, which is founded on relationality, interdependence, and vulnerability. Third, it explores how care ethics sees care as a practice and as an ethical framework, one which is sensitive to power hierarchies in caring relations and makes space for those who receive care to exercise agency. ${ }^{179}$ Following this discussion, the chapter reflects on the implications of seeing resettlement as a form of care, including making visible caring relations that may previously be hidden or "private," understanding the relationship between sponsors and refugees, exploring the identities of sponsors as caregivers, and recognizing that refugees are also caregivers in the midst of resettlement.

\subsection{Feminist Scholarship: Disrupting the Public-Private Dichotomy}

Drawing on decades of feminist scholarship that questions a dichotomy between private and public, Tronto argues for breaking down the "moral boundary" that "separates public and private life." 180 The gendered public-private dichotomy has traditionally separated women's roles in the "private" home from men's roles in the "public" sphere, valuing the contributions of men to public and political life, while devaluing the contributions of women to care work, and simultaneously excluding women from the public sphere and from politics. Care ethics argues that "care is devalued and the people who do caring work are devalued" with one exception being "when it is honored in its emotional and private

\footnotetext{
${ }^{179}$ While some have critiqued care ethics for not paying enough attention to the agency of those who receive care, Barnes and other scholars affirm the agency of those who receive care. See Marian Barnes, "Beyond the Dyad: Exploring the Multidimensionality of Care," in Ethics of Care: Critical Advances in International Perspective, ed. Marian Barnes et al. (Bristol: Policy Press, 2015), 36-38.

180 Tronto, Moral Boundaries.
} 
forms." ${ }^{181}$ The public-private dichotomy has served to assign care responsibilities to women and not men, devalue care as "women's work" that is inferior to other forms of work, and by separating the private from the public, exclude care from consideration as a public concern and political issue.

The phrase "the personal is political" - first written in a 1969 essay by feminist activist Carol Hanisch - became popularized within the feminist movement as a way to express how the concerns of women, which have traditionally been regarded as private and personal matters separate from politics, are in fact political issues influenced by political and economic structures, requiring collective political responses. ${ }^{182}$ For Tronto, a critical component of democracy is "giving people a voice in the allocation of caring responsibilities." ${ }^{\prime 183}$ This view of democracy repositions care from the private realm of personal relationships to the public realm of a collective, democratic political project. Moreover, although many care relations appear on the surface as seemingly personal relationships between two individuals, it is important to recognize "the significance of the broader sets of relationships within which relationships between those identified as care givers and care receivers are embedded." ${ }^{184}$ Feminist scholarship reveals how supposedly private issues and relationships are situated within broader social, political and economic structures, breaking down the separation between gendered public and private spheres.

\footnotetext{
181 Tronto, Moral Boundaries, 114, 122.

${ }^{182}$ Carol Hanisch, "The Personal Is Political," Writings by Carol Hanisch, 2009, http://www.carolhanisch.org/CHwritings/PIP.html; Scott Hammond, Political Theory: An Encyclopedia of Contemporary and Classic Terms (Westport: ABC-CLIO, LLC, 2008), 239-40.

183 Joan Tronto, "Democratic Caring and Global Care Responsibilities," in Ethics of Care: Critical Advances in International Perspective, ed. Marian Barnes et al. (Bristol: Policy Press, 2015), 27.

${ }^{184}$ Barnes, "Beyond the Dyad: Exploring the Multidimensionality of Care," 35.
} 


\subsection{Ethics of Care: Ontology, Practice and Ethics}

Care ethics begins with a relational ontology that humans always exist in relation with others, and that interdependence is a basic characteristic of human existence. ${ }^{185}$ Consequently, all humans are understood as vulnerable and interdependent, rather than just certain groups. ${ }^{186}$ Care ethics sees “'dependency' and 'vulnerability' not as conditions to be overcome, but rather as ways of being for normal human subjects." ${ }^{187}$ Carol Gilligan's book, In a Different Voice, first published in 1982, is viewed as the first to articulate an "ethic of care"; Gilligan described how girls and women responded to hypothetical moral dilemmas by expressing relationships and responsibility, as opposed to a more abstract and principle-based ethics. ${ }^{188}$ Joan Tronto's work identified the political implications of an ethics an care, ${ }^{189}$ while Virginia Held suggested that care ethics is suitable for understanding civil society, since civil society fosters social relations and often teaches caring values like listening attentively to others. ${ }^{190}$ Scholars have expanded the scope of analysis to articulate a global ethic of care, which among other things, interrogates questions of the responsibilities to care for strangers, including refugees and asylum seekers. ${ }^{191}$ It also highlights the importance of care and the limits of a rights-based

\footnotetext{
${ }^{185}$ Fiona Robinson, The Ethics of Care: A Feminist Approach to Human Security, Global Ethics and Politics (Philadelphia: Temple University Press, 2011), 4; Virginia Held, The Ethics of Care: Personal, Political, and Global (Oxford: Oxford University Press, 2006), 46; Marian Barnes et al., "Introduction: The Critical Significance of Care," in Ethics of Care: Critical Advances in International Perspective, ed. Marian Barnes et al. (Bristol: Policy Press, 2015), 3.

${ }^{186}$ Fiona Robinson, "Global Ethic of Care," Oxford Bibliographies Online, July 27, 2016, https://doi.org/10.1093/OBO/9780199743292-0182.

${ }^{187}$ Fiona Robinson, "Stop Talking and Listen: Discourse Ethics and Feminist Care Ethics in International Political Theory," Millennium - Journal of International Studies 39, no. 3 (2011): 845, https://doi.org/10.1177/0305829811401176.

${ }^{188}$ Carol Gilligan, In a Different Voice: Psychological Theory and Women's Development (Cambridge: Harvard University Press, 1982); Robinson, "Global Ethic of Care."

189 Tronto, Moral Boundaries.

${ }^{190}$ Held, The Ethics of Care, 131.

${ }^{191}$ Barnes et al., "Introduction: The Critical Significance of Care," 7.
} 
approach to understand "everyday insecurities," including for Syrian refugees. ${ }^{192}$ Scholars have also studied practices of care and social policy, comparing care policies across national contexts and analyzing care migration and transnational caregiving. ${ }^{193}$

Care can be understood as both a set of practices and as an ethical framework. Fisher and Tronto provide the following definition of caring:

On the most general level, we suggest that caring be viewed as a species activity that includes everything that we do to maintain, continue, and repair our 'world' so that we can live in it as well as possible. That world includes our bodies, our selves, and our environment, all of which we seek to interweave in a complex, life-sustaining web. ${ }^{194}$

As a process or practice, they suggest that care involves "caring about, noticing the need to care in the first place; taking care of, assuming the responsibility for care; care-giving, the actual work of care that needs to be done; and care-receiving, the response of that which is cared for to the care."195

Care can also be understood as an ethical framework to understand moral responsibilities. The link between the ethical framework of care and the practices of care is made explicit as "an ethics of care regards morality as existing not in a series of universal rules or principles that can guide action but in the practices of care through which we fulfill our responsibilities to particular others." 196 Virginia Held defines an ethics of care as "the compelling moral salience of attending to and meeting the needs of the particular others for whom we take responsibility." 197 This approach contrasts with approaches like Kantian

\footnotetext{
192 Fiona Robinson, "Feminist Care Ethics and Everyday Insecurities," in Ethical Security Studies: A New Research Agenda, ed. Jonna Nyman and Anthony Burke, Routledge Critical Security Studies Series (Abingdon: Routledge, 2016), 125.

193 Robinson, "Global Ethic of Care."

194 Tronto, Moral Boundaries, 103.

195 Ibid., 127.

196 Robinson, The Ethics of Care, 4.

${ }^{197}$ Held, The Ethics of Care, 10.
} 
ethics that rely on universal principles and with ethical approaches that "give primacy to such values as autonomy, independence, noninterference, fairness, and rights."198 Responsibility goes beyond obligation, which may be narrowly defined in law, to assess what people should do for others. ${ }^{199}$

Both individuals and societies may be assessed according to the standards of care ethics. As Tronto explains:

To be a morally good person requires, among other things, that a person strives to meet the demands of caring that present themselves in his or her life. For a society to be judged as a morally admirable society, it must, among other things, adequately provide for care of its members and its territory. 200

A care ethics perspective, therefore, enables scrutiny of both micro-relations of care and of macro-level structures that distribute caring responsibilities and provide care on a societal level. An ethic of care suggests how to respond morally within specific relationships. Tronto identifies four elements of an ethic of care: "attentiveness, responsibility, competence, and responsiveness." 201 Attentiveness is about recognizing the needs of others. ${ }^{202}$ Competence relates to the ability to provide adequate care, making the outcomes an important factor in determining whether care is ethical. ${ }^{203}$ Since care involves meeting needs, it asks whether the needs have been met. Finally, responsiveness refers to the "responsiveness of the care-receiver to the care."204 While taking into account the perspective of the one who receives care, it also pays attention to power dynamics within

\footnotetext{
${ }^{198}$ Held, The Ethics of Care, 129.

199 Tronto, Moral Boundaries, 133.

${ }^{200}$ Ibid., 126.

${ }^{201}$ Ibid., 127.

${ }^{202}$ Ibid., 127.

${ }^{203}$ Ibid., 133.

204 Ibid., 134.
} 
relations of care and "requires that we remain alert to the possibilities for abuse that arise with vulnerability." 205 Responding with care also involves ongoing critical reflection on specific contexts and relations: "Care as a practice involves more than simply good intentions. It requires a deep and thoughtful knowledge of the situation, and of all of the actors' situations, needs and competencies." ${ }^{206}$ To that end, listening is a moral practice. ${ }^{207}$

Scholarly analyses of policies ask critical questions around the provision of care: "who is entitled to care and on what terms, who is responsible for care, how care is valued and remunerated."208 As a feminist ethics, care ethics pays attention to how gender influences relations of care, ideas about care and the social distribution of care. In identifying the political implications of an ethic of care, Tronto noted that care is "gendered, raced, classed," with these categories determining "who cares and in what ways." ${ }^{209}$ In response, one goal of care ethics is to increase the social and political value of care and understanding of its importance. ${ }^{210}$

Care ethics is also concerned with the privatization or marketization of care, and aims to limit the influence of market values and market provision of care. ${ }^{211}$ Care ethics has developed in the context of neoliberal economic policies and values, including policies of austerity and cuts to caring services that harm the most vulnerable. ${ }^{212}$ An ethics of care approach views care as a collective responsibility, rather than an individual responsibility

\footnotetext{
205 Tronto, Moral Boundaries, 135.

206 Ibid., 136.

${ }^{207}$ Robinson, "Stop Talking and Listen," 853.

208 Robinson, The Ethics of Care, 4.

209 Tronto, Moral Boundaries, 112.

${ }^{210}$ Fiona Williams, "Care: Intersections of Scales, Inequalities and Crises," Current Sociology 66, no. 4 (July 2018): 557, https://doi.org/10.1177/0011392118765206.

${ }^{211}$ Held, The Ethics of Care, 124.

212 Barnes et al., "Introduction: The Critical Significance of Care," 9.
} 
or commodity that can be purchased on the market. ${ }^{213}$ The normative political project of creating a "caring society" aims to ensure that all people have their care needs met. ${ }^{214}$

Care ethics suggests that power hierarchies are important features of caring relations. Through analysis of care, "we are able to cast in stark relief where structures of power and privilege exist in society." 215 Tronto suggests that "caring about, and taking care of, are the duties of the powerful. Care-giving and care-receiving are left to the less powerful." ${ }^{216}$ In other words, those who identify needs and prescribe responses to care needs tend to hold power (such as policy-makers), while those who provide and receive care tend to hold less power. However, power is complex and "care ethics also suggests that relations of power are fluid and subject to constant change, and that both 'power' and 'dependence' can present themselves in many different ways." ${ }^{217}$

\subsection{Care Ethics and Refugee Agency}

Despite some misgivings about care and paternalism, a care ethics approach is not intended to deny agency to refugees or to suggest that refugees are passive recipients of care who are unable to care for themselves, two representations of refugees which are far too common in humanitarian practice. UNHCR has been critiqued for paternalism, ${ }^{218}$ and even the definition of resettlement - "the selection and transfer of refugees" from one state to another ${ }^{219}$ - recognizes the role of states and allows for organizations to be involved in

\footnotetext{
${ }^{213}$ Barnes et al., "Introduction: The Critical Significance of Care," 10.

${ }^{214}$ Held, The Ethics of Care, 136.

215 Tronto, Moral Boundaries, 175.

216 Ibid., 114.

${ }^{217}$ Robinson, "Stop Talking and Listen,” 852.

218 James Milner, "Refugees, Peacebuilding, and Paternalism: Lessons from Mozambique," in Refugees' Roles in Resolving Displacement and Building Peace : Beyond Beneficiaries, ed. Megan Bradley, James Milner, and Blair Peruniak (Washington: Georgetown University Press, 2019), 115-31.

${ }^{219}$ UNHCR, Resettlement Handbook, 3.
} 
selection and transfer, but sees refugees as passive beneficiaries. In contrast, a care ethics approach suggests that "interdependency is multidirectional" and breaks down the "care giver-care receiver dichotomy, ${ }^{, 220}$ while highlighting relations of care and power that are otherwise hidden. Tronto notes that despite the fact that all people have care needs, "one way that we socially construct those who need care is to think of them as pitiful because they require help." ${ }^{221}$ Care does not diminish autonomy but enables it: "the achievement of autonomy occurs out of a context within which one has been well cared for." ${ }^{222}$

Recent work in care ethics argues that recipients of care, who may be viewed as vulnerable bodies, have considerable political potential, in particular to demand that their care needs be met. ${ }^{223}$ For example, as a collective, the aging citizens in a welfare state can put pressure on the state to respond to their bodily care needs, a response which may involve broad political-economic processes from restructuring local government funding to facilitating international labour migration. ${ }^{224}$ Vaittinen draws on the concept of "bare life," developed by Agamben in relation to refugees, to suggest that although the mere existence of the physical body is often seen as apolitical, vulnerable bodies may exert pressure on the state and thus engage in politics. ${ }^{225} \mathrm{~A}$ care ethics approach acknowledges that even the most vulnerable have political agency, though it may come in different forms.

\footnotetext{
${ }^{220}$ Barnes, "Beyond the Dyad: Exploring the Multidimensionality of Care," 36-38.

221 Tronto, Moral Boundaries, 120.

222 Tronto, "Democratic Caring and Global Care Responsibilities," 27.

223 Tiina Vaittinen, “The Power of the Vulnerable Body," International Feminist Journal of Politics 17, no. 1 (January 2015): 102, https://doi.org/10.1080/14616742.2013.876301.

224 Ibid., 101.

225 Ibid., 102.
} 
Similarly, Nyers suggests that refugees are frequently denied but still maintain political agency. ${ }^{226}$ Nyers contrasts representations of refugees to citizens:

the refugee is constituted through a series of ontological omissions: whatever is present to the political subject (i.e., citizen) is absent to the refugee. The qualities of visibility, agency, and rational speech of the citizen-subject are conspicuously absent in conventional representations of refugees that cast them as invisible, speechless, and, above all, nonpolitical. 227

Nevertheless, while refugees "are not supposed to be political agents...refugees are everywhere demonstrating political agency." 228 Despite representations and practices that attempt to deny agency to refugees, they creatively exercise political agency. A care ethics approach to agency offers a useful corrective to the refugee-citizen dichotomy, by making the ontological argument that all humans are dependent and vulnerable but nevertheless have agency, which can they exercise in different ways as they are embedded in caring relations where they experience hierarchies of power.

\subsection{Refugee Resettlement as Care: Making Care Visible}

This thesis argues that refugee resettlement is a form of care, and as such, can benefit from analysis using a care ethics approach. Returning to Fisher and Tronto's definition of caring, ${ }^{229}$ resettlement involves "maintaining and repairing selves" through meeting the material, emotional and relational needs of refugees as they settle in a new country. In terms of the process of care, refugee resettlement involves "caring about" when governments decide to engage in resettlement and make decisions on who to resettle,

\footnotetext{
${ }^{226}$ Peter Nyers, Rethinking Refugees: Beyond States of Emergency, Global Horizons (New York: Routledge, 2006).

227 Ibid., 3.

228 Ibid., xvii.

229 Tronto, Moral Boundaries, 103.
} 
"taking care of" when actors from NGOs to sponsors make commitments to specific refugee families (such as a sponsor signing a sponsorship undertaking), "care-giving” when sponsors, governments, and settlement agencies meet the concrete financial and settlement needs of refugees, and "care-receiving" as refugees respond and actively participate in the resettlement process.

Recognizing that resettlement is a form of care raises questions about the distribution of responsibilities for care. As explained in Chapter 1, in the Canadian resettlement system, questions about state responsibility, privatization, and the appropriate distribution of financial and settlement responsibilities for resettled refugees have been debated for over forty years. Although the refugee sponsorship literature does not draw on care ethics specifically, the most significant criticism of private sponsorship is that it privatizes state responsibility, which bears similarities to how care ethics views care as a collective responsibility and aims to resist the influence of neoliberal values in the provision of care. Seeing resettlement as care also demands an in-depth investigation of the diverse caring relations that are meeting the care needs of refugees, leading to a focus not only on prominent policies and programs but also on more informal care arrangements that may be hidden when there is only attention on official programs. The next chapter looks for the hidden caring relations within the GAR program, finding that the broad bureaucratic category obscures the diverse caring relations in practice.

Some of the literature on private sponsorship examines the micro-level relationships between sponsors and sponsored refugees. Scholars have analyzed this relationship drawing on concepts of a "pastoral rationality,"230 a "master-dependent

\footnotetext{
${ }^{230}$ Lippert, "Rationalities and Refugee Resettlement."
} 
relationship, ${ }^{, 231}$ kinship metaphors, ${ }^{232}$ frameworks of Orientalism, ${ }^{233}$ the re-establishment and recognition of pre-conflict social roles, ${ }^{234}$ and the achievement of stability for refugees by the end of the sponsorship period. ${ }^{235}$ Similar to care ethics, many of these scholars identify the power dynamics and hierarchies inherent in the sponsorship relationship. The work of Kyriakides and colleagues counters a narrative of passive refugees by calling PSRs "persons of self-rescue" and comes close to a care ethics idea of responsiveness by highlighting how refugees respond to the care they receive and how they may exercise agency in determining the goals for the sponsorship relationship. ${ }^{236}$

Care ethics acknowledges that caring relations can be problematic, and become "relations of domination, oppression, injustice, inequality, or paternalism." ${ }^{237}$ Similarly, the literature on refugee sponsorship recognizes that the sponsorship relationship is not always positive and the power imbalance between sponsors and refugees can be problematic. One philosopher notes that "while sponsorship groups ought to aim at securing the independence and autonomy of newcomers, they can sometimes behave in culturally inappropriate and paternalistic ways. ${ }^{.238}$ As a consequence, she argues that

\footnotetext{
${ }^{231}$ Kwok B. Chan and Lawrence Lam, "Resettlement of Vietnamese-Chinese Refugees in Montreal, Canada: Some Socio-Psychological Problems and Dilemmas," Canadian Ethnic Studies 15, no. 1 (January 1983): $1-17$.

${ }^{232}$ Macklin et al., "Kindred Spirits? Links Between Refugee Sponsorship and Family Sponsorship."

${ }^{233}$ Christopher Kyriakides et al., "Beyond Refuge: Contested Orientalism and Persons of Self-Rescue," Canadian Ethnic Studies 50, no. 2 (August 2018): 59-78, https://doi.org/10.1353/ces.2018.0015.

${ }^{234}$ Christopher Kyriakides et al., "Status Eligibilities: The Eligibility to Exist and Authority to Act in Refugee-Host Relations," Social Forces, 2018, https://doi.org/10.1093/sf/soy109; Christopher Kyriakides et al., "Transactions of Worth in Refugee-Host Relations," in Strangers to Neighbours: Refugee Sponsorship in Context, ed. Shauna Labman and Geoffrey Cameron (Montreal: McGill-Queen's University Press, forthcoming 2020); Kyriakides et al., "Beyond Refuge."

235 Patti Tamara Lenard, "How Do Sponsors Think about 'Month 13'?," Refuge: Canada's Journal on Refugees 35, no. 2 (June 2019): 64-73.

${ }^{236}$ Kyriakides et al., "Status Eligibilities"; Kyriakides et al., "Transactions of Worth in Refugee-Host Relations"; Kyriakides et al., "Beyond Refuge."

${ }^{237}$ Robinson, The Ethics of Care, 5.

${ }^{238}$ Lenard, "Resettling Refugees," 301.
} 
private sponsorship programs "require oversight to protect refugees who are, otherwise, at the mercy of private sponsorship groups in a range of ways." ${ }^{239}$ Similarly, drawing on social egalitarianism, Lim argues that "because clearly demarcated relationship boundaries are often absent in private sponsor-refugee relationships, refugees are rendered vulnerable to domination and infantilization." ${ }^{240}$ In response, Lim argues that "to continue without threatening the social equality of refugees, states must introduce a number of additional refugee-protecting measures" such as clear definitions of sponsor role-responsibilities in terms of specific tasks, and compulsory training for sponsors. ${ }^{241}$ While these studies rightly heed Tronto's call to "remain alert to the possibilities for abuse that arise with vulnerability, ${ }^{242}$ they also reproduce the stereotype of vulnerable refugees needing protection from a protector state.

A study of Syrian refugees found that "the settlement experience of PSRs relies heavily on their sponsors and varies considerably based on the sponsors' commitment, experiences, and understanding of what it takes for a refugee to settle in a new country."243 Whereas some PSRs were well-supported over and above government requirements (such as by extending sponsorship beyond one year), other sponsors met the government's requirements but did not give extra support, while still other sponsors abandoned refugee families and did not meet the requirements. ${ }^{244} \mathrm{~A}$ recent edited collection on resettlement suggests that in humanitarian governance care is combined with control over the lives of

\footnotetext{
${ }^{239}$ Lenard, "Resettling Refugees," 301.

${ }^{240}$ Desiree Lim, "Social Egalitarianism and the Private Sponsorship of Refugees," Journal of Social Philosophy 50, no. 3 (2019): 302, https://doi.org/10.1111/josp.12294.

${ }^{241}$ Ibid., 302, 318.

242 Tronto, Moral Boundaries, 135.

${ }^{243}$ Agrawal, "Canadian Refugee Sponsorship Programs."

244 Ibid.
} 
refugees. ${ }^{245}$ Applying care ethics to resettlement provides a useful corrective, as responsiveness is a critical feature of an ethical relation.

Given that care ethics situates care relations within broader social, relational and political contexts, this thesis makes explicit the connections between micro-level relationships, such as between sponsors and refugees, and broader policy and governance structures. As scholars have explained: "sponsors interact with refugees at the granular, quotidian level of daily life, but the possibility, structure, and terms of that relationship are set by government regulation." 246 Lim points out that even when sponsors are family members or friends of refugees, as is often the case in the PSR program, they simultaneously "act as agents of the state" and "by endowing private groups or individuals with legal sponsorship status, the state is essentially appointing them the executors of a central policy goal: ensuring that refugees are successfully resettled." 247

While not drawing on care ethics specifically, Enns reflects on how citizen involvement in refugee resettlement leads to greater responsibilities and relations of care:

neoliberal processes of decentralisation and privatisation have decreased the moral distance between local actors and refugees. On a simplified level, involving individual citizens and disseminating efforts within a greater number of communities literally decreases the distance between newcomers and the receiving community. It is presence that makes visible the Other and asserts a need to engage and interact. These moments of immediacyboth in respect to space and time - facilitate a stronger caring response. ${ }^{248}$

\footnotetext{
${ }^{245}$ Adèle Garnier, Liliana Lyra Jubilut, and Kristin Bergtora Sandvik, "Introduction: Refugee Resettlement as Humanitarian Governance: Power Dynamics," in Refugee Resettlement: Power, Politics, and Humanitarian Governance, ed. Adèle Garnier, Liliana Lyra Jubilut, and Kristin Bergtora Sandvik (New York: Berghahn Books, 2018), 2.

${ }^{246}$ Macklin et al., “A Preliminary Investigation into Private Refugee Sponsors," 36.

${ }^{247}$ Lim, "Social Egalitarianism and the Private Sponsorship of Refugees," 316.

248 Enns, "The Opportunity to Welcome," 50.
} 
In the language of care ethics, a greater community focus in resettlement, through both private sponsorship and localized supports for government-selected refugees, facilitates both the steps of "caring about, noticing the need to care in the first place" and "taking care of, assuming the responsibility for care" as well as the ethical response of attentiveness. ${ }^{249}$

\subsection{Who is Caring for Refugees?}

Tronto noted that care is "gendered, raced, classed," with these categories determining "who cares and in what ways." 250 In the context of refugee resettlement, although some analyses show how refugee identities impact resettlement experiences, ${ }^{251}$ there is a limited understanding of how gender, race and class operate within the system. Although sponsorship has traditionally been a project of faith-based organizations, sponsors are becoming increasingly diverse.

Two recent studies have explored the demographics of sponsors. An online selfselected survey of 530 sponsors of Syrian refugees found that $74 \%$ of respondents were women, $88 \%$ identified with European heritage, $79 \%$ were born in Canada, $47 \%$ identified as Christian, ${ }^{252}$ over $84 \%$ had obtained a Bachelor's degree or above, over half had beforetax household incomes above $\$ 100,000,74 \%$ were over 50 years of age, and $43 \%$ were retired or semi-retired. ${ }^{253}$ Although the authors acknowledge the survey respondents may not be representative of sponsors generally, they suggest that sponsors "are disproportionately white, well-educated, middle to upper class women over fifty." ${ }^{254}$ They

\footnotetext{
249 Tronto, Moral Boundaries, 127.

250 Ibid., 112.

${ }^{251}$ See Setareh Ghahari et al., "The Life Experiences of Refugees in Canada: A Comprehensive Scoping Review to Identify Unmet Needs and Barriers," Journal of International Migration and Integration, November 2019, https://doi.org/10.1007/s12134-019-00727-3.

${ }^{252}$ Another 38\% identified as non-religious, agnostic or atheist; $6 \%$ as Jewish; and $2 \%$ as Muslim.

${ }^{253}$ Macklin et al., "A Preliminary Investigation into Private Refugee Sponsors,” 45-46.

254 Ibid., 53.
} 
conclude that "age and stage, together with time and resources, are clearly important factors shaping people's desire and ability to undertake sponsorship."255

Another sample of 204 sponsors, this time drawn from 95 of the 150 groups who participated in the 2018 BVOR fund, found similar results. ${ }^{256}$ Among the respondents, $67 \%$ were women, 70\% were born in Canada, and $85 \%$ had obtained a Bachelor's degree or above. However, the sponsors in this sample were generally younger and had lower incomes: only $32 \%$ were above retirement age, and about one third had household incomes under $\$ 70,000$, perhaps reflective of the financial support provided as part of the BVOR fund that reduced the financial barrier to sponsorship. The gender, racial, class, religious and age characteristics of sponsors merit further study, ${ }^{257}$ especially since in contrast to sponsors, resettled refugees are often young, Muslim, visible minorities, with lower levels of education. In the paid settlement sector in Canada, women also dominate. ${ }^{258}$ However, many settlement workers come from immigrant and minority ethno-religious backgrounds. $^{259}$ Analyzing the distribution of care highlights how individuals and institutions provide care within broader social and power structures like gender and race.

\subsection{Refugees as Caregivers}

It is important to note that resettled refugees are not just recipients of care, but they are also caregivers. Silvius shows that in addition to caring for family members in Canada, resettled refugees often have transnational family obligations and are frequently "contributing care

\footnotetext{
${ }^{255}$ Macklin et al., “A Preliminary Investigation into Private Refugee Sponsors,” 45-46.

${ }^{256}$ Refugee Hub, “2018 BVOR Fund Sponsor Experience Survey,” Refugee Hub, 2019, https:/docs.google.com/presentation/d/1aj36S4oNrMoLi4RH0Q_coCdKuiVaYV3hDILGopg7WtU/edit?us $\mathrm{p}=$ sharing\&usp=embed_facebook.

${ }^{257}$ Macklin et al., "A Preliminary Investigation into Private Refugee Sponsors," 53.

258 Türegün, "Immigrant Settlement Work in Canada."

259 Ibid., 406-7.
} 
and economic resources to a household in another country, or, minimally, tending to the emotional and material needs of their family members abroad." ${ }^{260}$ Drawing on Social Reproduction Theory and research with resettled refugees in Winnipeg, he shows the “complex care and emotional labour required by resettled refugees to manage conditions of prolonged family separation." ${ }^{261}$ Within Canada, neoliberal policies mean that resettled refugees often must participate in wage labour instead of participating in language training and education, especially given the challenges of accessing and affording housing, while care obligations limit inclusion in the labour market. ${ }^{262}$ Sponsoring relatives to Canada through private sponsorship is one way refugees may care for their relatives overseas. ${ }^{263}$

\subsection{Conclusion}

This chapter has explored how care ethics may contribute to understanding refugee resettlement in Canada. First, challenging the public-private dichotomy can make visible relations of care that were previously hidden, undervalued, or privatized. Second, an ethics of care proposes important elements of ethical relations, such as attentiveness, listening and responsiveness. Third, seeing resettlement as care raises critical questions around the distribution of responsibilities and hierarchies of power. The next chapter explores the hidden caring relations subsumed under the "Government-Assisted Refugees" category, showing that despite its presentation as a "public" or government program, volunteers, sponsors and NGOs are actively involved in caring for and caring alongside refugees.

\footnotetext{
${ }^{260}$ Ray Silvius, "Work, Social Reproduction, the Transnational Household, and Refugee Resettlement: A Canadian Case Study:," Critical Sociology, (February 2019), 2, https://doi.org/10.1177/0896920518820936.

261 Ibid., 2.

262 Ibid., 5.

263 Ibid.
} 


\section{Chapter 3: "Public" Resettlement: How NGOs, Volunteers and}

\section{Sponsors Support Government-Assisted Refugees}

The way I see it there are two commitments: there's the government and us Canadians corporately in our responsibilities or commitments we are making to the UNHCR and resettling the cases they refer, which is important. BVOR and JAS are a part of that...But you also have this, in some ways, hybrid situation where you have Convention refugees being resettled who may be vulnerable and would be selected by UNHCR in need of resettlement but maybe not, but the important factor is they have family members in Canada. So that is really what drives the PSR program...I think that's really the important question: what is our commitment to UNHCR and is the government expecting private citizens to take that on $?^{264}$

The next two chapters are organized around these commitments. This chapter examines the commitment to UNHCR-referred refugees through the GAR, BVOR and JAS programs as well as more informal arrangements, while the next chapter examines the PSR program. Drawing on case studies of the Syrian and Yazidi resettlement initiatives, it argues that while the BVOR program is explicitly presented as a public-private partnership, the GAR program is also a public-private partnership, not only because of its implementation by NGO settlement agencies, but also because of its reliance on volunteers and sponsors.

As noted in Chapter 1, traditionally the government has viewed resettlement to Canada as public, private or blended, which today correspond to GAR, PSR and BVOR. From a bureaucratic perspective, these categories usefully distinguish between different levels of government financial commitment. However, they obscure the complex and diverse caring relations within each category, such as by subsuming and counting JAS cases under the broader GAR category, despite the contributions of sponsors. Settlement services generally also rely extensively on volunteers: $79 \%$ of settlement agencies use

\footnotetext{
${ }^{264}$ Brian Dyck (National Migration and Resettlement Coordinator, Mennonite Central Committee Canada), interview with author, December 13, 2019.
} 
volunteers to support the provision of IRCC-funded settlement services. ${ }^{265}$ Since the introduction of the Host Program in 1984, matching programs involving Canadian volunteers and refugees have been a feature of the Canadian resettlement program. ${ }^{266}$ Figure 2 illustrates the diverse models that have emerged to support the settlement needs of UNHCR-referred and government-selected refugees in Canada.

Figure 2 Models for Supporting UNHCR-Referred Refugees in Canada

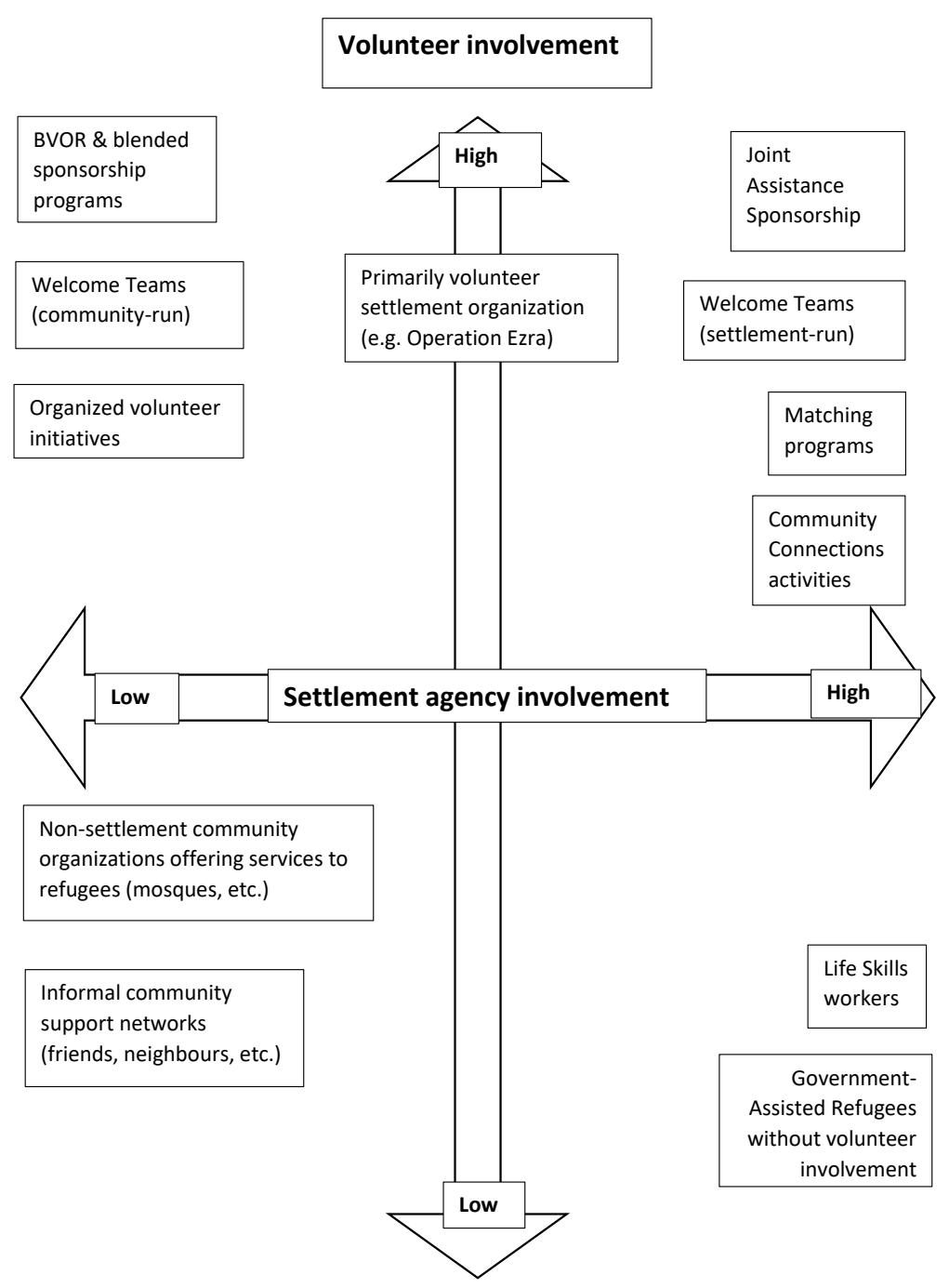

${ }^{265}$ Evaluation Division, "Evaluation of the Settlement Program," 11.

${ }^{266}$ Evaluation Division, "Evaluation of the Host Program," 7. 
Under the classic GAR model, refugees receive support exclusively from professional settlement agencies. The Life Skills program, operated by settlement agencies and funded by IRCC as part of the Resettlement Assistance Program for GARs, trains members of an ethno-cultural community to work with refugees from their linguistic and cultural background on life skills, covering topics such as safely living in an apartment building, making calls to request services and help in emergencies, using the transportation systems, and accessing and navigating all other relevant services for newcomers. ${ }^{267}$ These Life Skills workers, who might be most accurately described as para-professionals, receive an honorarium for their work, and work for around 20 to 30 hours with each family.

Many settlement agencies have a Community Connections program. IRCC defines Community Connections as "activities to support the two-way process of integration and facilitate adaptation on the part of newcomers and their host communities" which may include "peer support groups, community-based group events, conversation circles, matching newcomers with Canadians, cultural visits, [and] field trips." ${ }^{268}$ Community Connections replaced the Host Program in 2008, and involves a broader range of activities beyond volunteer matching programs. ${ }^{269}$ It is primarily a social program with the goal of lasting friendships, and volunteers may help with shopping, help find employment, or celebrate special occasions together. ${ }^{270}$ However, the volunteer commitment is significantly less than a sponsorship, with less people involved (only one Canadian family

\footnotetext{
267 Tam Dam (Resettlement Assistance Program Manager, London Cross-Cultural Learning Centre), interview with author, February 19, 2020.

268 Evaluation Division, "Evaluation of the Settlement Program," 2.

${ }^{269}$ Evaluation Division, "Evaluation of the Host Program," ix.

${ }^{270}$ Anonymous, interview with author, December 4, 2019.
} 
or person matched to each GAR family), and meetings typically happening once a week. ${ }^{271}$ Community Connections is a large program that is open to all categories of immigrants, and 79,000 newcomers participated in 2017-2018. ${ }^{272}$ Although Community Connections encompasses various programs, nearly 27,000 newcomers participated in matching programs with volunteers in 2015/2016. ${ }^{273}$ The size of the program merits its consideration as an important care arrangement in the Canadian resettlement system.

JAS is a program with high settlement agency involvement and high volunteer involvement. Both overseas JAS referrals and in-Canada JAS referrals receive the initial six weeks of services under the Resettlement Assistance Program. If the family was not referred to JAS prior to arrival, a JAS recommendation may be made after needs assessment following arrival, or later on. After arrival or following a referral to JAS, the sponsor meets with the agency, local IRCC staff and the refugee family. The settlement agency and sponsor continue to work together closely to support the family, with sponsors providing the supports listed on the JAS recommendation and supporting families in following up with appointments. JAS provides complementary support to what is available through the settlement agency, with a focus on emotional support and home visits. Only SAHs are allowed to sponsor JAS cases, and prospective groups "are advised to demonstrate [to the local IRCC office] that they have sufficient experience to accommodate the refugee's special needs" before IRCC will approve the match. ${ }^{274}$

\footnotetext{
271 Anonymous, interview with author, December 4, 2019.

272 IRCC, "2017-2018 Departmental Results Report," 29.

${ }^{273}$ Evaluation Division, "Evaluation of the Settlement Program," 36.

${ }^{274}$ IRCC, "Refugee Sponsorship Application: Joint Assistance Sponsorship (IMM 5493)," Government of Canada, last modified March 31, 2017, https:/www.canada.ca/en/immigration-refugeescitizenship/services/application/application-forms-guides/guide-5493-refugee-sponsorship-applicationjoint-assistance-sponsorship.html.
} 
Welcome Teams are inspired by the sponsorship model and match refugee families with groups of five or more volunteers. These welcome team programs may be initiated and run by settlement agencies. In Saint John, New Brunswick, the local settlement agency usually received 60-70 GARs per year, but during the Syrian initiative was receiving about 60-70 Syrian GARs per week and 450 Syrians in four months. ${ }^{275}$ As a response, they proactively set up volunteer Welcome Teams who helped with many of the initial settlement tasks usually undertaken by the settlement agency, such as finding and setting up an apartment. Similarly, a settlement agency in Peterborough, Ontario set up GAR Support Groups. ${ }^{276}$ Alternatively, these welcome teams may be initiated and run by community organizations, such as the Together Project, which matches GAR families and more recently refugee claimants across Ontario with Welcome Groups. ${ }^{277}$

The case of Operation Ezra for Yazidis, which began as a sponsorship group and later received some government funding for transportation and settlement staff, shows how volunteer initiatives may become somewhat incorporated into the formal settlement structure through funding and become "quasi-governmental entities." ${ }^{278}$ Other community organizations outside of the resettlement system also provide services to GARs. For example, Syrian GARs reported receiving goods, such as food, and services, such as assistance filling out tax forms, from local mosques. ${ }^{279}$ Finally, there is anecdotal evidence

\footnotetext{
275 Jordan Mattie, A Resettlement Story: The Saint John Syrian Refugee Response (Saint John, New Brunswick, 2017), https:/www.youtube.com/watch?v=7KNmfH7MxkA\&t=236s.

${ }^{276}$ Craig Damian Smith, Tea Hadžiristić, and Lina Alipour, "Filling the Gap: Volunteer \& Settlement Sector Interactions In Response to the Syrian Refugee Crisis" (Toronto: Together Project, September 2017), 39, https://togetherproject.ca/site/uploads/2018/03/Together_Project_Report_Filling_the_Gap.pdf.

277 Together Project, "Matching," Together Project, accessed March 28, 2020, https://togetherproject.ca/matching/.

278 Pearlman, "Operation Ezra: A New Way Forward."

279 Agrawal, "Canadian Refugee Sponsorship Programs.”
} 
of informal community support networks providing support to GARs, such as neighbours assisting a family who has moved into their neighbourhood. ${ }^{280}$

Looking through the lens of finances, all of these models except blended programs like BVOR have the same financial implications for government and are formally counted under the GAR category in resettlement statistics. However, viewing the GAR program through this bureaucratic lens misses the diverse of relations of care and critical role of volunteers within the program. This chapter will now explore two case studies: the Syrian initiative that demonstrates the importance of volunteers, and the Yazidi initiative that demonstrates the rise of the in-Canada JAS program and other JAS-like arrangements.

\subsection{Volunteers and the Syrian initiative}

One interview participant maintained: "The Syrian project did not belong to the Government of Canada, it belonged to the citizens of Canada." ${ }^{281}$ It is clear that volunteers played a critical role in the Syrian initiative, beyond those who were involved as sponsors. As mentioned above, the Welcome Teams established for GARs in Saint John, New Brunswick are one example. Other volunteers became involved through existing programs, such as the Community Connections program. When one settlement agency had 48 hours at the end of December to transform vacant apartments in a private building into 25 housing units for Syrian refugees who were about to arrive, staff and volunteers worked together, with staff working additional hours to make it possible. ${ }^{282}$ Many settlement agencies as

\footnotetext{
${ }^{280}$ Sabine Lehr (Private Sponsorship of Refugees Manager, Inter-Cultural Association of Greater Victoria), interview with author, January 24, 2020.

281 Anonymous, interview with author, December 4, 2019.

282 Ibid.
} 
part of the extra funding available through Operation Syria were able to fund a volunteer coordinator position specific to Syrian refugees.

The Operation Syrian Refugees National Strategic Plan suggested that "matching Canadian families with Syrian families as soon as possible after arrival in Canada will provide essential support and promote social cohesion." ${ }^{283}$ When asked where they found help finding food and clothing, Syrian refugees mentioned "sponsors, RAP SPOs, friends, church members, community members and volunteers." 284 The Together Project's survey of volunteer initiatives during the Syrian initiative examined volunteer initiatives in rural areas, mid-size cities and large cities in Ontario, finding 67 initiatives in Ontario alone. ${ }^{285}$ They found in nearly every place "volunteers, civil society, and settlement agencies cooperating to match under-supported Government Assisted Refugees."286 Their typology of volunteer initiatives classifies initiatives as novel/grassroots for new initiatives that emerged specifically to respond to the needs of Syrian refugees, pre-existing/repurposed initiatives that already existed in response to other needs but began programming and supports for Syrian refugees, and organized/devoted initiatives that were prepared to support Syrian refugees. ${ }^{287}$ They assessed initiatives for complementarity with the settlement sector, sustainability, and scalability to other contexts, finding mixed results, with some initiatives completely separate from the settlement sector and others closely integrated with the settlement sector. ${ }^{288}$ The Together Project concluded that "actively

\footnotetext{
283 Government of Canada. Obtained under Access to Information Request A-2016-00251.

${ }^{284}$ Evaluation Division, "Evaluation of the Syrian Initiative," 12.

285 Smith, Hadžiristić, and Alipour, "Filling the Gap."

286 Ibid., 9.

287 Ibid., 22.

288 Ibid., 23.
} 
including citizens in integration is thus not limited to private sponsorship and its attendant financial and legal responsibilities."289

However, there were significant challenges for settlement agencies in mobilizing volunteers while preparing to welcome large numbers of refugees in a short period of time. Settlement agencies were overwhelmed with large numbers of volunteers, who were sometimes very selective in what they wanted to do, and volunteer recruitment processes, such as criminal record checks, can take a long time. ${ }^{290}$ One interview participant at the height of the Syrian initiative "was talking to RAP-SPOs and they would say we didn't have time to think about new programs, we were just going to the airport all the time." 291 The Together Project concluded that "while volunteer management and coordination with the settlement sector improved over time, many volunteers lost interest, were not properly mobilized, or provided support that overlapped or conflicted with settlement sector service provision." ${ }^{292}$ Similarly, the government's evaluation of the Syrian initiative found that volunteers were helpful, but that coordination challenges were significant. ${ }^{293}$

An IRCC memorandum from early 2016 identified ten top emerging policy and program issues for the Syrian population, two of which relate to volunteers: "a need to develop a more consistent and clear pathway for corporate donations and volunteers" and "matching Syrian refugee families with Canadian citizens and their families to establish

\footnotetext{
${ }^{289}$ Smith, Hadžiristić, and Alipour, "Filling the Gap," 9.

${ }^{290}$ Anonymous, interview with author, December 4, 2019.

${ }^{291}$ Brian Dyck (National Migration and Resettlement Coordinator, Mennonite Central Committee Canada), interview with author, December 13, 2019.

292 Smith, Hadžiristić, and Alipour, "Filling the Gap," 15.

${ }^{293}$ Evaluation Division, "Evaluation of the Syrian Initiative," 31.
} 
and expand social connections leading to better resettlement and integration outcomes." ${ }^{294}$ In terms of matching programs, it noted that settlement agencies "expressed concerns that the current Community Connections programming no longer adequately reflects the need for HOST-type programming, in particular due to cancelling of dedicated settlement funding for coordinators." The Host Program, which ran from 1984 to 2008, funded "Host Coordinator" positions at settlement agencies, who would recruit volunteers, train volunteers, match volunteers and participants, organize activities and monitor matches. ${ }^{295}$

Volunteers have played an important gap-filling role in smaller communities where settlement services are limited or non-existent. My home region in small-town Nova Scotia welcomed seventeen families of different nationalities during the Syrian initiative, almost all through BVOR. When there were no summer English programs because schools for children and English classes for adults were closed, the coordinator of the English for Academic Purposes program at Acadia University started a summer program. ${ }^{296}$ Volunteer retired teachers taught classes, community members volunteered as classroom assistants and provided childcare for the youngest children, and volunteer drivers transported most of the families to the university. In its first year, the program offered classes and activities four days a week, serving forty newcomer participants and involving about 100 community volunteers, the majority of whom were not members of a local sponsorship group.

\footnotetext{
${ }^{294}$ IRCC, "Memorandum to the Assistant Deputy Minister: Top Policy and Program Issues: Resettlement/Settlement and Integration of Syrian Refugees," 2016, obtained under Access to Information request A-2016-37379.

${ }^{295}$ Evaluation Division, "Evaluation of the Host Program," 11.

${ }^{296}$ Sharon Churchill in Rachel McNally, "Community Refugee Sponsorship and Integration in Rural Nova Scotia" (Honours thesis, Acadia University, 2018), 37, https://scholar.acadiau.ca/islandora/object/theses\%3A2643/.
} 


\subsection{Yazidi Resettlement and In-Canada Joint Assistance Sponsorship}

In resettlement statistics, JAS cases are included under the GAR category. Since the financial cost to the government is the same as a GAR case, the government does not count the extra care work that sponsors undertake as worthy of a separate category. Given that refugees are referred to the in-Canada JAS program when they struggle with integration, the JAS program essentially creates a system where sponsors act as back-up caregivers when government-funded settlement services fail to achieve integration goals. The contributions of sponsors through JAS are understudied. The Canadian Council for Refugees, reflecting on the 2007 evaluation of the PSR program, called it a "significant omission" that the report neglected to include the role of sponsors in JAS. ${ }^{297}$ Similarly, IRCC's 2016 Evaluation of the Resettlement Programs examined the GAR, PSR and BVOR programs, but neglects to even mention that JAS exists.

Prior to 2017, JAS was a small program, with the notable exception of the Kosovar evacuation. In considering options for Yazidi resettlement, IRCC noted that only 93 people (29 cases) were resettled under JAS in 2015 (it is unclear if that includes in-Canada JAS cases). ${ }^{298}$ The in-Canada variation has only recently become popular as a policy tool to respond to refugees with high settlement needs. Refugee Sponsorship Training Program bulletins show that the promotion of the in-Canada JAS program has increased substantially since the beginning of 2017. Only four cases were promoted in the three years

\footnotetext{
${ }^{297}$ Canadian Council for Refugees and Sponsorship Agreement Holder representatives, “Comments on Private Sponsorship of Refugees Evaluation” (Canadian Council for Refugees, September 2007), https://ccrweb.ca/files/psrevalcomments.pdf.

${ }^{298}$ IRCC, "Memorandum to the Minister: Yazidi Religious Minority: Background and Preliminary Analysis of a Proposal from One Free World and the Office for Refugees of the Catholic Archdiocese of Toronto" F-880544, obtained under Access to Information request A-2017-01375.
} 
between 2014 and 2016, compared to 75 cases between 2017 and 2019. The number of cases available to sponsors has also grown from 22 cases on November 17, 2017, to 38 cases on April 6, 2018, to 60 cases August 10, 2018, to 65 cases on September 4, 2019.

This timing coincides with the government's Yazidi resettlement initiative. As mentioned in chapter 1, the Yazidis arrived as GARs but faced significant integration challenges due to their experiences of trauma and resulting severe mental health issues, a high number of single mothers, low levels of education and other barriers. In many cases, sponsors were requested through the in-Canada JAS program. Of the sample of 100 inCanada JAS profiles, $52 \%$ were refugees from Iraq, with the vast majority of these cases being Yazidi survivors of Daesh. Most of the referrals came from the four cities where Yazidis were resettled. At one point in January 2018, there were 23 Yazidi cases available for sponsorship under the JAS program. ${ }^{299}$ In January 2020, there were 59 in-Canada JAS cases waiting to be matched with sponsors, most of which were refugees from Iraq. ${ }^{300}$ These figures show that the rise of the in-Canada JAS program can largely be attributed to the need to address the high settlement needs of the Yazidi population. The conversion of so many Yazidi cases to JAS suggests that the government and government-funded settlement agencies have attempted to shift the care of this population largely onto sponsors, meaning that sponsors are left responsible for the integration of a high-needs population that came to Canada through a political commitment.

Although Yazidi single mothers with several minor children appear to be the most common profile under the JAS program, Yazidis have not been the only ones referred to

\footnotetext{
${ }^{299}$ Refugee Sponsorship Training Program Bulletin, January 12, 2018.

${ }^{300}$ Refugee Sponsorship Training Program, "JAS Refugee Profiles,” accessed January 31, 2020.
} 
the JAS program in recent years. Of the 119 JAS profiles analyzed, $23 \%$ of the cases were Syrians, while 11 other countries were represented in smaller percentages. Figure 3 shows the reasons for referral to the JAS program. As it makes clear, most JAS cases meet multiple JAS criteria, and trauma from violence or torture, as well as medical needs or disability, are especially common.

Figure 3 Reasons for Referral to the Joint Assistance Sponsorship Program ${ }^{301}$

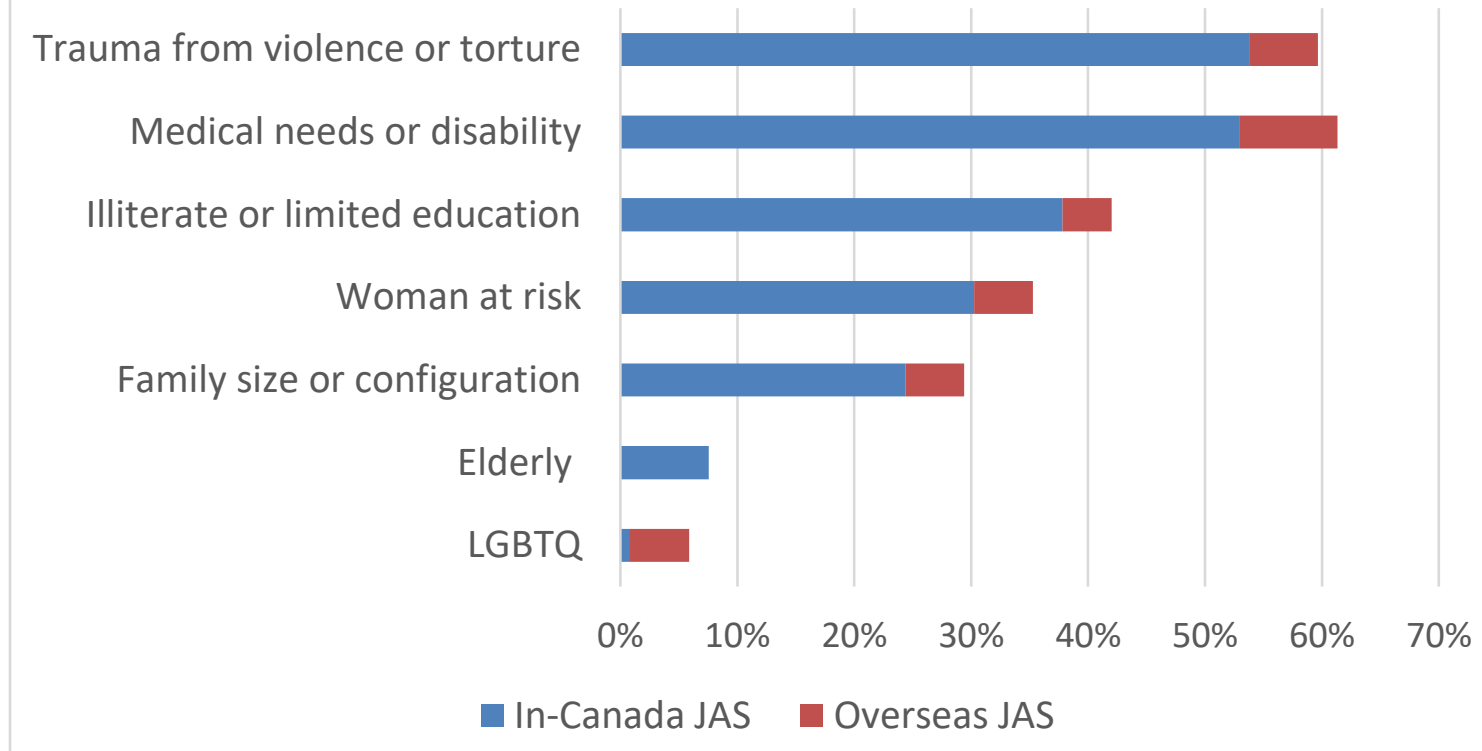

It is important to note that not all UNHCR-referred refugees who meet JAS criteria are referred for a JAS sponsorship. Some BVOR cases meet at least one of the JAS criteria, though in 2017, BVOR cases were selected from the broader UNHCR-referred refugee population based on family configuration (generally smaller families or large families with younger children), and low settlement and health needs. ${ }^{302}$ These criteria seem to be based

\footnotetext{
${ }^{301}$ Based on the analysis of 100 in-Canada JAS profiles and 19 overseas JAS profiles, as described in the methodology. Those profiles with extended profiles available include these reasons for referral as a checklist, while the remaining profiles were coded by the researcher based on the description of the case. ${ }^{302}$ Refugee Sponsorship Training Program, "Blended Visa Office Referred (BVOR) Program Frequently Asked Questions,” 2017, http:/www.rstp.ca/wp-content/uploads/2014/03/Blended-VOR-FAQ_2017-11.pdf.
} 
on what kind of refugees sponsors are willing and able to support. In 2016, 408 women came to Canada under the Women at Risk program, including an unknown number of women with higher settlement needs who came through JAS, while others may have arrived through BVOR or GAR. ${ }^{303}$ A BVOR case may be converted to JAS after arrival, but only in "exceptional circumstances." 304 Nevertheless, it raises the question of whether BVOR is sometimes taking the place of JAS, but with less government financial support and without access to the initial settlement services through the RAP. In that case, BVOR can represent a degree of "privatization" of the JAS program.

The in-Canada JAS program is intended for situations when high resettlement needs are only known after arrival. However, given that it was known in advance that survivors of Daesh had suffered serious trauma, and the most vulnerable among this group were chosen with a focus on women at risk, the Yazidis would seem to be the archetype of a JAS case. One may question why the entire group was not referred to JAS from the outset, as had been done with the Kosovars nearly 20 years earlier. Indeed, in June 2016, even prior to the House of Commons motion to resettle Yazidis, representatives of a SAH and a human rights NGO met with the Minister of Immigration's office to discuss a detailed proposal to identify and resettle 1,600 Yazidis under JAS, and they had already been in contact with potential sponsoring groups across the country. ${ }^{305}$ Similarly, in December 2016, Operation Ezra submitted a proposal to the government for a hybrid initiative with

\footnotetext{
${ }^{303}$ Minister of Immigration, Refugees and Citizenship, “Annual Report to Parliament on Immigration 2017" (Ottawa: IRCC, 2017), 32, https://www.canada.ca/content/dam/ircc/migration/ircc/english/pdf/pub/annual-report-2017.pdf. ${ }^{304}$ IRCC, "Operational Bulletin 646."

${ }^{305}$ IRCC, "Memorandum to the Minister: Yazidi Religious Minority: Background and Preliminary Analysis of a Proposal from One Free World and the Office for Refugees of the Catholic Archdiocese of Toronto" F-880544, obtained under Access to Information request A-2017-01375.
} 
government funding and private sector integration support. ${ }^{306}$ The proposal suggested that most of the Yazidis come as GARs with some PSRs, but private organizations could be involved in identifying refugees who are relatives of Yazidis in Canada, coordinating integration (through government-funded Integration Coordinators), engaging businesses to provide in-kind donations, putting on cultural events, matching newcomer Yazidis with local Yazidi and Canadian families, and supporting informal English acquisition through volunteers. ${ }^{307}$ As of June 2020, the government had not responded to the proposal. ${ }^{308}$ The government did acknowledge in January 2017 when creating the public policy to resettle survivors of Daesh that "given the trauma experienced by this population, many will require extended income and health support beyond the one year that is normally provided to refugees" ${ }^{\prime 309}$ which seems to indicate a consideration that the JAS portion of income support may be required. However, there was not a proactive effort by the government to match survivors of Daesh with sponsors prior to arrival.

In addition to formal conversions of GAR cases to JAS cases, in two of the cities where Yazidis GARs resettled, community organizations stepped up to provide JAS-like support. In Toronto, Project Abraham established volunteer welcome teams for each Yazidi GAR family. ${ }^{310}$ As mentioned in Chapter 1, in Winnipeg Operation Ezra has supported over 300 Yazidi GARs and PSRs and the organization received funding from IRCC to

\footnotetext{
${ }^{306}$ Chair of Operation Ezra, interview with author, February 4, 2020.

307 Operation Ezra, "Yazidi Rescue Program Highlights" (Operation Ezra, December 19, 2016).

${ }^{308}$ Chair of Operation Ezra, interview with author, February 4, 2020.

309 IRCC, "Memorandum to the Minister: Temporary Public Policy to Facilitate the Resettlement of Survivors of Daesh in Northern Iraq," F-912043, January 17, 2017, obtained under Access to Information request A-2017-01375.

${ }^{310}$ Debbie Rose and Gary Rose, "Report on the Challenges of the Yazidi Refugees" (Project Abraham, Mozuud Resettlement and Support for Victims of Persecution, December 1, 2017), 5.
} 
continue to assist GARs. ${ }^{311}$ In her statement to the Standing Committee on Citizenship and Immigration during their study on Yazidi resettlement, Shauna Labman explained:

What the witnesses made apparent to me is the degree to which the government resettlement is dependent on Canadian volunteer support. One Free World International's brief noted that they're working to "bridge the gap in services" in Toronto. The work of both Project Abraham, also in the GTA, and Operation Ezra in Winnipeg seem to confirm this gapfilling need. For me, while commending the amazing work of these organizations, it does raise concerns where volunteer gap fillers are not present $[\ldots]$ these initiatives are illustrating a privatization of settlement support by Canadian volunteers $[\ldots]$ Given these increased numbers to private sponsorship moving forward, it's important to recognize the pull of privatized Canadian support and to assess what this may do to the gap-filling capacity of private Canadians, as has been articulated with respect to the Yazidi refugees and their settlement. ${ }^{312}$

Similarly, Pearlman writing about Operation Ezra argues that the fact that "the government is funding a private sponsorship group highlights the problem of government overreliance on private sponsors to mitigate resettlement shortfalls" when "sponsors expect government funding of the settlement services sector to be sufficient to support [GARs]." ${ }^{\prime 313}$ The Chair of Operation Ezra strongly supported hybrid programs with the private sector involved in settlement support, but maintained that the government and not sponsors should take financial responsibility for refugee resettlement:

I believe the responsibility to settle refugees, like the Yazidi refugees who are the victims of a genocide, should not fall on the shoulders of the private sector. The private sector should be engaged, absolutely, in a hybrid type of program where we provide assistance, but in terms of expecting the private sector to privately sponsor a people who is the victim of a genocide, I think that is completely inappropriate...Government relying on the private sector to be the main source of sponsorship is not a practical, realistic or meaningful plan because the private sector can only do so much. What it should be is the government working with the private

\footnotetext{
311 Pearlman, "Operation Ezra: A New Way Forward."

${ }^{312}$ Standing Committee on Citizenship and Immigration, "Evidence," CIMM 42nd Parliament, 1st Session (House of Commons of Canada, November 30, 2017), 10, https://www.ourcommons.ca/DocumentViewer/en/42-1/CIMM/meeting-88/evidence\#Int-9820056.

313 Pearlman, "Operation Ezra: A New Way Forward."
} 
sector, and the government bringing in families with the private sector helping in the settlement, like we've done. It would allow for refugees to be sponsored in greater numbers and it would allow for more successful settlement... Private sector should partner with existing government infrastructure, because the existing government infrastructure is restricted, and understandably so, by their staffing, they just don't have enough people. People are working 9-5, volunteers work at night and volunteers work on weekends...Financially speaking, the government is where the money is, obviously that's why everybody pays taxes. It would be their responsibility to foot the bill, and in terms of settlement, they should really reach out to organized agencies across the country actually, and religious entities, churches and synagogues are a good place to start. Many of them would be very interested in formal hybrid programs whereby a particular congregation is helping the government settle three to four families. ${ }^{314}$

It is clear that there is a challenge with capacity within the settlement sector, particularly for supporting high-needs refugee populations. As Project Abraham pointed out in relation to Yazidis in Toronto, settlement workers "can each have more than 70 families in their case load, which leaves traumatized refugees isolated and without the full support they need." 315 Operation Ezra started the food bank program for GARs because government assistance is not sufficient to cover basic needs. ${ }^{316}$ However, not all Yazidi resettlement cities had these civil society groups who were organized to step in to provide support for Yazidi GARs. In the sample of in-Canada JAS cases, Calgary had by far the highest number of JAS referrals, which may point to a lack of alternative support structures initiated by civil society. Both formally through the in-Canada JAS program and informally through volunteer community organizations, sponsors and volunteers filled gaps in capacity in the settlement sector by providing direct settlement support for Yazidi refugees.

The rise of the in-Canada JAS program also coincides with a government initiative to promote the program. A government operational bulletin from December 2017 aims "to

\footnotetext{
${ }^{314}$ Chair of Operation Ezra, interview with author, February 4, 2020.

${ }^{315}$ Rose and Rose, "Report on the Challenges of the Yazidi Refugees," 4.

${ }^{316}$ Chair of Operation Ezra, interview with author, February 4, 2020.
} 
improve the overall outcomes of the refugees by providing them with the appropriate level of support they require to successfully integrate... and to increase the overall number of JAS referrals nationally." 317 This initiative makes the assumption that sponsors will be willing to assume responsibilities for the unpaid care work, and given the needs of these refugees, these responsibilities are significant. However, it is not clear that this assumption is true. In the RSTP bulletins, many JAS cases were promoted to sponsors multiple times, sometimes over a period of several months, meaning that many cases are not sponsored quickly (or possibly not sponsored at all). In addition, 60 cases that were posted in June were still available for sponsorship in September.

As mentioned in chapter 1, similar challenges have emerged within the BVOR program in the last two years, leading to the BVOR fund to financially incentivize BVOR sponsorship. Despite private sector donors covering the sponsor portion of the financial responsibility, the uptake among sponsors has been well under the targets set by the government. The limited uptake of both the JAS and BVOR programs despite no or limited financial responsibility for sponsors seems to point to the time and emotional energy required to fulfill care responsibilities as more significant barriers to sponsorship than financial barriers. Sponsors also face competing demands for their care work. For example, on April 6, 2018, sponsors were being asked to consider 114 BVOR cases, 44 Visa OfficeReferred cases (with no government financial support), and 38 in-Canada JAS cases, ${ }^{318}$ in addition to the target of 18,000 PSRs in $2018 .{ }^{319}$

\footnotetext{
${ }^{317}$ IRCC, "Operational Bulletin 646."

${ }^{318}$ RSTP Bulletin, April 6, 2018.

${ }^{319}$ IRCC, "Notice - Supplementary Information 2018-2020 Immigration Levels Plan," Government of Canada, November 1, 2017, https://www.canada.ca/en/immigration-refugees-

citizenship/news/notices/supplementary-immigration-levels-2018.html.
} 


\subsection{Partnering to Care: Supporting Refugee Caregivers through JAS}

As mentioned in chapter 2, it is important to remember that refugees are not just recipients of care, but also caregivers. The JAS profiles highlight some of the challenges that refugee caregivers face. In the sample of JAS cases, $38 \%$ are single mothers. One criteria for referral to JAS is a large family size or an unusual family configuration, for example: "a 20 -year-old woman from Iraq who is raising her young sister, is the primary caregiver of her elderly grandmother and her brother who is suffering from impaired cognitive disabilities. ${ }^{320}$ Another criteria for referral is trauma, which may impact a refugee's ability to fulfill care responsibilities: "the mother struggles with prior trauma, and has difficulty in caring for her children while adjusting to life in Canada." ${ }^{321}$ Care responsibilities can pose challenges in terms of integration: "while the [refugee] is enrolled in full time English classes, many are missed due to his spouse's medical appointments and having to care for their two young children." ${ }^{322}$ Meanwhile, extended family and other support networks have been disrupted due to displacement and resettlement: "she has no friends or family living locally that could help her take care of her nine minor children." 323 The JAS program invites sponsors to not only care for refugees, but care alongside them.

\subsection{Caring about Versus Care-Giving: The Government-NGO Power Hierarchy}

What I find interesting about resettlement...is this sense of ownership everybody has throughout the resettlement continuum. Because UNHCR thinks we do resettlement because we identify [refugees]... the governments they think they do [resettlement] because they do the actual selection and the legal [processing], and the people who work in

\footnotetext{
${ }^{320}$ In-Canada JAS PROFILE \#: 19-0345, profiled in the RSTP bulletin, April 26, 2019.

${ }^{321}$ In-Canada JAS PROFILE \#: 19-0836, profiled in the RSTP bulletin, September 13, 2019.

${ }^{322}$ In-Canada JAS PROFILE \#: 19-0497, profiled on the RSTP website, September 4, 2019.

${ }^{323}$ In-Canada JAS PROFILE \#: 19-0173, profiled on the RSTP website, September 4, 2019.
} 
integration think they do [resettlement] because they do the actual integrating and that's really what resettlement means. ${ }^{324}$

Care ethics predicts a power hierarchy between those who structure responses to care needs and those who provide care. Tronto argues that "caring about, and taking care of, are the duties of the powerful. Care-giving and care-receiving are left to the less powerful." ${ }^{325}$ In the context of resettlement, care ethics would predict a hierarchy of power between the government - who identifies refugees, defines refugee policy, and funds refugee settlement - over settlement provider NGOs, who provide care on the ground.

In examining the politics of the relationship between the government and settlement agencies, this hierarchy is evident. Enns, discussing the role of municipal governments, sponsors and NGOs in the Syrian initiative suggests that "decisions, determinations and destinations are made by the federal government, then outsourced to communities to carry out the tasks." ${ }^{326}$ One settlement agency suggested that the title 'Government-Assisted Refugees' "works for bureaucratic reasons but it is the people who make it work." 327

One settlement agency described their relationship with IRCC as a "one-sided relationship" saying that "IRCC makes decisions and expects us to follow." ${ }^{328}$ As one example, IRCC decided to reduce the number of settlement agencies within a region and as a result cut the agency's funding. That decision was made without consulting the settlement agencies in the region or the broader community, and there was a lack of clarity in the criteria used to make the decision. The agency who suddenly lost their funding would

\footnotetext{
${ }^{324}$ Michael Casasola (Senior Resettlement Officer, UNHCR Canada), interview with author, February 3 , 2020 .

325 Tronto, Moral Boundaries, 114.

326 Enns, "The Opportunity to Welcome," 52.

${ }^{327}$ Anonymous, interview with author, December 4, 2019.

328 Ibid.
} 
have appreciated participating in a consultation and sharing their expertise but were not given that opportunity.

Similarly, despite ongoing needs in the Yazidi community in Winnipeg, in April 2020 , IRCC cut its funding of $\$ 110,000$ per year to Operation Ezra, which had covered 1.5 staff positions and transportation for programs for the past three years. ${ }^{329}$ As a result, Operation Ezra has needed to fundraise in the private sector to retain its staff in order to continue helping Yazidi GAR families who are still struggling with the integration process in Canada. As another example, one settlement agency explained that IRCC often tries to dictate how the Executive Directors of settlement agencies spend their time and more generally how administrative dollars are used, yet there was resistance to this power since the directors of settlement agencies are not employees of IRCC, and settlement agencies receive funding from various sources, not just IRCC. ${ }^{330}$ The Allies in Refugee Integration Project, which is trying to improve collaboration between sponsors and settlement agencies suggested that: "at the end of the day there are power dynamics. The government is the funder and are seen as the big boss, so some agencies don't always have room to innovate or do things differently." 331

While settlement agencies can refer GAR cases to JAS, IRCC makes the final decision on case conversions. One settlement agency explained "sometimes we get refused, even though from our point of view this family should be eligible. But later on, IRCC says no, they would not consider this case really needs JAS." ${ }^{332}$ In one or two cases, the agency

\footnotetext{
${ }^{329}$ Chair of Operation Ezra, interview with author, February 4, 2020.

${ }^{330}$ Anonymous, interview with author, December 4, 2019.

${ }^{331}$ Staff from the Allies in Refugee Integration Project, interview with author, February 18, 2020.

332 Tam Dam (Resettlement Assistance Program Manager, London Cross-Cultural Learning Centre), interview with author, February 19, 2020.
} 
explained that "according to us they need too much emotional support, but later on at IRCC they review the case and say no, there are other cases with more heavy needs than this family, so they say no they would not consider that." As mentioned in the introduction, categorizing is an important form of power, and ultimately the government still retains the power to decide which cases qualify as JAS.

However, this hierarchical relationship does not mean that NGOs are without power to influence resettlement policy. One settlement agency suggested that although they do not do selection, they have a voice through mechanisms such as conference calls on the GAR program and the National GAR-RAP Working Group. ${ }^{333}$ As one example of a policy change that was recommended by settlement agencies, the government now sometimes waives travel loans in cases where it is clear the refugee will not be able to repay it.

Michael Casasola from UNHCR explained that settlement agencies are not just “implementers" but "they're actually impacting - indirectly - policy, just by their stated capacity. ${ }^{334} \mathrm{He}$ told the story of how settlement agencies were struggling with increased numbers of GARs, and several large centres asked the government to stop sending GARs. Many settlement agencies were complaining to the government that it was difficult to find housing for large families in a short period of time, as IRCC only funds temporary accommodations for about two weeks. In response, for a period of time the government told UNHCR not to submit for resettlement any families over six people. As a result, the settlement agencies were "indirectly impacting who Canada selects by virtue of their

\footnotetext{
333 Tam Dam (Resettlement Assistance Program Manager, London Cross-Cultural Learning Centre), interview with author, February 19, 2020.

${ }^{334}$ Michael Casasola (Senior Resettlement Officer, UNHCR Canada), interview with author, February 3 , 2020 .
} 
inability, their claimed inability to integrate." This example of integration-related criteria impacting selection caused concern for UNHCR. Instead of changing selection criteria, Casasola wondered whether sending refugees to smaller centres may be a solution as there is more housing available for large families.

\subsection{A "Caring" Approach? Government Bureaucracy versus NGO Care}

Tronto identifies four elements of an ethic of care: "attentiveness, responsibility, competence, and responsiveness." ${ }^{335}$ Settlement agency staff spoke about a contrast between the government bureaucratic approach to resettlement and a more holistic NGO approach. One settlement agency asserted that the government makes decisions based on statistics and numbers, and sometimes "loses perspective," but their agency takes a "holistic perspective." ${ }^{336}$ For example, while the government prioritizes moving as many people through a reception centre as quickly as possible, the agency considers the needs of each individual family to see whether it is best or possible to move a family right away, and the needs and safety of the client come first in all decisions. ${ }^{337}$ This approach lines up with the call for attentiveness to individual needs. Similarly, definitions of integration could usefully benefit from the care ethics principles of attentiveness and responsiveness. Representatives from the Allies in Refugee Integration Project wondered:

Is the way that IRCC sees integration and settlement outcomes really a good reflection of what's happening on the ground? So I think people's idea of someone being integrated or reaching their settlement goals are very different...The newcomer needs to be the owner of those goals... [integration] right now is really perceived as something that's being almost dictated or evaluated without the newcomer still being involved in pursuing their own priorities and goals based on their level of education,

\footnotetext{
335 Tronto, Moral Boundaries, 127.

${ }^{336}$ Anonymous, interview with author, December 4, 2019.

337 Ibid.
} 
their income, where they're coming from, their context...having a more client-centered idea and metrics would be really beneficial. ${ }^{338}$

Care ethicist Marian Barnes argues that "we need to also consider how those responsible for making policies for care, but whose jobs do not require them to come into direct contact with care receivers, can develop and practise the attentiveness necessary to create the policy and institutional contexts necessary for care." ${ }^{339}$ In a decentralized system where the government bureaucracy is far removed from everyday interactions with refugees, and where refugees have little input into the measurements of integration that drive funding and programming, the care ethics principles of attentiveness and responsiveness suggest engaging refugees in defining the goals of care and how to achieve them.

\subsection{The Future of Government Resettlement}

Post-Syrian initiative, the target number of GARs has been steadily increasing for several years: 7,500 in $2018,9,300$ in $2019,10,700$ in $2020,10,950$ in 2021 , and 11,450 in $2022 .{ }^{340}$ The target for BVOR remains steady at 1,000 for 2020-2022 (a number that was not possible to reach in 2018) and the target for PSR remains steady at 20,000 for 2020-2022. ${ }^{341}$ One of the Canadian Council for Refugees' three advocacy priorities for 2019 is for the government to bring 20,000 GARs annually, which would match the current PSR numbers but nearly double the current GAR numbers. ${ }^{342}$ While bringing 20,000 GARs would

\footnotetext{
${ }^{338}$ Staff from the Allies in Refugee Integration Project, interview with author, February 18, 2020.

${ }^{339}$ Barnes, "Beyond the Dyad: Exploring the Multidimensionality of Care," 38.

${ }^{340}$ IRCC, "Notice - Supplementary Information 2018-2020 Immigration Levels Plan"; IRCC, "Notice Supplementary Information 2019-2021 Immigration Levels Plan," Government of Canada, October 31, 2018, https://www.canada.ca/en/immigration-refugees-citizenship/news/notices/supplementaryimmigration-levels-2019.html; IRCC, "Notice - Supplementary Information 2020-2022 Immigration Levels Plan," Government of Canada, March 12, 2020, https://www.canada.ca/en/immigration-refugeescitizenship/news/notices/supplementary-immigration-levels-2020.html.

${ }^{341}$ IRCC, "Supplementary Information 2020-2022 Levels Plan."

342 Canadian Council for Refugees, "Priorities for Refugees and Vulnerable Migrants 2019" (Canadian Council for Refugees, April 1, 2019), https://ccrweb.ca/sites/ccrweb.ca/files/advocacy-priorities-2019.pdf.
} 
require a significantly larger investment of government financial resources, it also raises questions about which care arrangements would be equipped to meet the increased care needs. The Canadian Council for Refugees argues that "in our response to the Syrians, we have shown that we have the infrastructure and the capacity to resettle." ${ }^{343}$

However, as this chapter has shown, the success of the Syrian initiative relied on widespread volunteer mobilization, in addition to significant extra work for settlement agencies and their staff. Given the extensive reliance on volunteers in supporting UNHCRreferred refugees, it is unclear whether the volunteer capacity would be able to increase to support increased GAR care needs, alongside needed investments in the formal settlement agency systems, particularly given declining public attention on resettlement post-Syrian initiative. Many of the volunteer initiatives identified in the Together Project's report were organized specifically to help Syrian refugees, ${ }^{344}$ and it is not clear that this interest will transfer to other refugee populations. IRCC funding allowed settlement agencies to hire volunteer coordinators for the Syrian initiative, but this funding has since been cut, meaning that the settlement sector faces greater challenges in coordinating volunteers. The general feeling of settlement agencies in response to this proposal is that it is not so simple to just bring more people, and they would need significantly more resources and staff to welcome more GARs. ${ }^{345}$ UNHCR is pushing for higher resettlement numbers around the world, but in the context of Canada, which is currently increasing resettlement numbers as part of growing immigration admissions, UNHCR is focusing advocacy on priority

\footnotetext{
${ }^{343}$ Canadian Council for Refugees, "Priorities for Refugees and Vulnerable Migrants 2019."

${ }^{344}$ Smith, Hadžiristić, and Alipour, "Filling the Gap," 19.

${ }^{345}$ Michael Casasola (Senior Resettlement Officer, UNHCR Canada), interview with author, February 3 , 2020 .
} 
populations and the development of complementary pathways, such as refugee access to economic immigration programs. ${ }^{346}$

The Together Project's report on volunteer initiatives during the Syrian initiative argued that "the settlement sector and the Government of Canada should work together to offer more space for volunteer engagement." ${ }^{347}$ It makes several recommendations, including IRCC funding for volunteer coordinators in settlement agencies; an innovation fund to support and scale-up successful volunteer initiatives; public consultations to document the various volunteer initiatives that emerged during the Syrian initiative; public education on the role of the settlement sector; partnerships between the settlement sector and volunteer initiatives; and better understanding for volunteers and sponsors of rights, responsibilities, and the need to protect vulnerable refugees. ${ }^{348}$ Providing government funding to promising volunteer initiatives, as happened in the case of Operation Ezra, is an interesting proposal that would further blur the distinctions between public and private.

In terms of sponsorship, both the BVOR program and JAS program face challenges in recruiting sponsors and remaining sustainable. ${ }^{349}$ Returning to the question posed at the beginning of this chapter: "what is our commitment to UNHCR and is the government expecting private citizens to take that on? And I think the BVOR program the way it's trending shows that Canadians aren't willing to do that." ${ }^{350}$ Various initiatives and proposals have tried to engage civil society in BVOR, including the BVOR funds in 2018

\footnotetext{
${ }^{346}$ Michael Casasola (Senior Resettlement Officer, UNHCR Canada), interview with author, February 3 , 2020 .

347 Smith, Hadžiristić, and Alipour, "Filling the Gap," 6.

348 Ibid., 10-13.

349 Shauna Labman and Jennifer Hyndman, "BVOR Briefing Note” (Centre for Refugee Studies, York University, May 1, 2019), https://crs.info.yorku.ca/files/2019/04/BVOR-Briefing-2019-May1.pdf.

${ }^{350}$ Brian Dyck (National Migration and Resettlement Coordinator, Mennonite Central Committee Canada), interview with author, December 13, 2019.
} 
and 2019, ${ }^{351}$ an initiative that gives SAHs more PSR spaces for sponsoring BVOR cases, ${ }^{352}$ promotional activities, and proposals for new models of hybrid programs. One proposal for the government to fund 12 months of income support through BVOR was rejected. ${ }^{353}$ Similarly, despite a government goal to promote in-Canada JAS cases, given that the uptake among sponsors has been limited, it is not possible to always rely on sponsors being available to support refugees with high needs.

One of the challenges with finding sponsors is that there is a "limited pool of groups" interested in unnamed sponsorships, and "if you've got BVOR, and you've got JAS, you've got the same groups that would be looking at the same sort of things." ${ }^{354}$ For UNHCR, a fundamental challenge is "how do you design that program that responds to protection, provides the refugee with privacy, yet maintains the interest of the volunteer, because that same group of volunteers could be doing something else?"355 Despite concerns about privatization, keeping sponsorship focused on refugee protection "may require aiming Canadian volunteerism more toward community hosting and supporting successful refugee claimants and government-assisted refugees." 356 The BVOR and JAS programs both respond to protection needs by sponsoring UNHCR-referred refugees, yet they both struggle to recruit and retain sponsors who are willing to care for strangers.

\footnotetext{
${ }^{351}$ Refugee Hub, "News Release"; Refugee Hub, "PRESS RELEASE."

352 Refugee Sponsorship Training Program, "BVOR News” (Refugee Sponsorship Training Program, January 2019), http://www.rstp.ca/wp-content/uploads/2019/07/BVOR-news-7-January-2019.pdf.

${ }^{353}$ Michael Casasola (Senior Resettlement Officer, UNHCR Canada), interview with author, February 3 , 2020.

${ }^{354}$ Brian Dyck (National Migration and Resettlement Coordinator, Mennonite Central Committee Canada), interview with author, December 13, 2019.

${ }_{355}$ Michael Casasola (Senior Resettlement Officer, UNHCR Canada), interview with author, February 3 , 2020.

356 Labman, "Conclusion: Sponsorship's Success and Sustainability?”
} 
There are a variety of reasons why involving volunteers in supporting GARs may be desirable. One study that asked Syrian GARs how the program could be improved found that they "were concerned about limited opportunities to mix with the Canadian-born to try out the English they were learning in their language classes" despite regular events like picnics organized by settlement agencies to connect refugees and Canadian families. ${ }^{357}$ Many initiatives have emerged to fill gaps in the settlement sector. Reflecting on the challenges of resourcing the settlement sector to provide similar support as sponsors, one interview participant commented: "there is certainly a need to resource the settlement sector better so that capacity is increased to provide support, at the same time acknowledging that the connection to community that is provided through the sponsorship group adds another layer to the settlement capacity, and that is difficult to replicate with the settlement sector alone." ${ }^{358}$ Many have discussed the societal benefits of involving Canadian volunteers in welcoming refugees in terms of welcoming communities. Brian Dyck suggested that involving volunteers and sponsors "has really changed the narrative in Canada and allowed space for refugee resettlement in Canada, so there isn't the same level of hesitancy or resistance toward refugees in Canada that there is in the European states or the United States or a number of other places." ${ }^{359}$ This logic has also been used by the Global Refugee Sponsorship Initiative to promote a BVOR-like model, ${ }^{360}$ but can easily apply to any program that involves citizens to a high degree in welcoming refugees.

\footnotetext{
357 Agrawal, "Canadian Refugee Sponsorship Programs.”

${ }^{358}$ Emilie Coyle (Former Director of National Programs, Refugee Hub), interview with author, December 16, 2019.

${ }^{359}$ Brian Dyck (National Migration and Resettlement Coordinator, Mennonite Central Committee Canada), interview with author, December 13, 2019.

${ }^{360}$ Global Refugee Sponsorship Initiative, "Who We Are."
} 


\subsection{Conclusion}

The Government-Assisted Refugee program is generally perceived as a "public" program and the opposite of "private" sponsorship. This chapter has questioned this dichotomy and the idea of resettlement as a state-based activity by showing how community-based organizations and citizen volunteers are involved in significant ways in supporting GARs. Looking at resettlement in Canada through a bureaucratic lens sees the system in terms of government financial responsibilities and only counts three categories: GAR, BVOR and PSR. However, looking through a lens of care reveals extensive and diverse care arrangements within the GAR category. Beyond formal sponsorship through the JAS program, volunteers are involved in welcome teams modeled after private sponsorship, matching programs run by settlement agencies, grassroots volunteer initiatives, and informal community support networks that operate entirely outside of the formal settlement structure. Many of these initiatives have played a gap-filling role to make up for limitations in the formal settlement structure. Most GARs interact with volunteers in some capacity during their first months and years of resettlement. While volunteer involvement was particularly high in response to Syrian refugees, volunteers have long been essential to supporting government resettlement. 


\section{Chapter 4: "Private" Resettlement: How the Government Supports}

\section{Private Sponsorship of Refugees}

One of the most striking features globally if you look at [resettlement], is that if the United States indeed resettles only 18,000 people...the Private Sponsorship of Refugees Program in Canada is not just resettling double the number of what our government resettles... Volunteers are running the single largest resettlement program in the world. ${ }^{361}$

As discussed in chapter 1, scholars and advocates alike have critiqued the Canadian government for privatizing the state responsibility of resettlement, especially because of rising PSR numbers and the introduction of the BVOR program. However, the literature is beginning to acknowledge that a narrative of privatization misses the ways that government supports enable private sponsorship. Private sponsorship has grown significantly, from about 3,000 refugees per year in the 1990 s to 20,000 refugees per year today. ${ }^{362}$ As a result, it has become, as the quote above identifies, "the single largest resettlement program in the world." This chapter further questions a public-private dichotomy by exploring the various ways the government is involved in private sponsorship: direct and indirect financial contributions, regulation, processing, training and capacity-building, monitoring and settlement services. It investigates the relationships between the government and sponsors, and between sponsored refugees and government-funded settlement services.

Separate logics drive the private sponsorship program versus the programs for UNHCR-referred refugees discussed in the previous chapter. Returning to the idea of two separate commitments, private sponsorship is not generally perceived as privatization by

\footnotetext{
${ }^{361}$ Sabine Lehr (Private Sponsorship of Refugees Manager, Inter-Cultural Association of Greater Victoria), interview with author, January 24, 2020.

${ }^{362}$ Michael Casasola (Senior Resettlement Officer, UNHCR Canada), interview with author, February 3, 2020 .
} 
sponsors given the focus on family reunification: "I don't think a lot of people if any in the PSR program are thinking we're doing this to take some responsibilities off the government, they're doing this because they know someone who they want to get out of a refugee situation, and they have this avenue." ${ }^{363}$ Family reunification also responds to one of the objectives of the Immigration and Refugee Protection Act: "to support the selfsufficiency and the social and economic well-being of refugees by facilitating reunification with their family members in Canada." ${ }^{364}$ As mentioned in chapter 2, sponsoring relatives is one way that resettled refugees may care for their family members overseas. ${ }^{365}$

Many sponsors, faced with government caps on the number of applications they can submit and often waitlists, are supportive of rising PSR numbers, as they want to bring more family members and other named refugees to Canada. ${ }^{366}$ In part, privatization is a question of levels of analysis, with individual SAHs wanting to bring as many of their cases as possible, while a systemic analysis raises different issues: "those of us that are...looking at broader issues beyond what is in front of us on the table in terms of sponsorship requests would say yes, [rising PSR numbers] is a concern for a number of reasons." ${ }^{367}$ One of these concerns is the capacity of SAHs to manage an increasing number of sponsorships.

\subsection{Government Financial Contributions to Private Sponsorship}

From a financial perspective, it is clear that private sponsorship reduces but does not eliminate costs to government compared to other programs. Michael Casasola from

\footnotetext{
${ }^{363}$ Brian Dyck (National Migration and Resettlement Coordinator, Mennonite Central Committee Canada), interview with author, December 13, 2019.

364 Government of Canada, Immigration and Refugee Protection Act, sec. 3.

365 Silvius, "Work, Social Reproduction, the Transnational Household, and Refugee Resettlement."

${ }^{366}$ Sabine Lehr (Private Sponsorship of Refugees Manager, Inter-Cultural Association of Greater Victoria), interview with author, January 24, 2020.

367 Ibid.
} 
UNHCR suggested that 'I wouldn't call it privatizing because...there are still costs to government whatever you do...PSR had a price tag [but] GARs had a bigger price tag. But the government is responding to the willingness of Canadians to try to resettle refugees." ${ }^{\text {368 }}$ There are cost-savings to government in terms of monthly income support and in funding for the RAP. Between 2011 and 2015, the average yearly cost per GAR was $\$ 10,573$, including $\$ 5,871$ in monthly income support, $\$ 1,425$ for start-up costs, and $\$ 2,716$ for settlement agencies to deliver the RAP. ${ }^{369}$ However, for private sponsorship there are various direct and indirect costs covered by the government. As noted in Chapter 1, other scholars have concluded that the government's willingness to cover these costs is an important reason that private sponsorship is possible in Canada. ${ }^{370}$

First, sponsors do not have to pay any costs to submit an application. In 2015, the processing cost for a GAR case was $\$ 1,621$, whereas the processing cost for a PSR case was very similar at $\$ 1,550 .{ }^{371}$ Second, the government funds the Refugee Sponsorship Training Program, with its network of trainers across Canada, to offer workshops, webinars, resources, and other training and support to private sponsors, especially those who are not connected to a SAH. Third, the Interim Federal Health Program covers prescription drugs, counselling and other services for PSRs during their first year, on top of provincial health programs. Fourth, refugees access other provincial and local public services, especially healthcare and education. Fifth, other government benefits, especially the Canada Child Benefit, are important sources of income for resettled refugee families

\footnotetext{
${ }^{368}$ Michael Casasola (Senior Resettlement Officer, UNHCR Canada), interview with author, February 3 , 2020 .

${ }^{369}$ Evaluation Division, "Evaluation of the Resettlement Programs," 37-38.

${ }^{370}$ Hyndman, Payne, and Jimenez, "The State of Private Refugee Sponsorship in Canada," 12.

371 Evaluation Division, "Evaluation of the Resettlement Programs," 37.
} 
under any program. It was estimated that the government would pay $\$ 76.6$ million in child benefits to Syrian families between July 2016 and June 2017, including PSRs, GARs, and BVORs. ${ }^{372}$ Finally, as permanent residents, PSRs are eligible for government-funded settlement services, especially language classes. Resettled refugees use on average $\$ 10,867$ worth of settlement services in their first 15 years in Canada, not including the RAP provided to GARs. ${ }^{373}$

\subsection{Sponsored Refugees and Government-Funded Settlement Services}

There is increasing overlap between the private sponsorship infrastructure and the settlement infrastructure, through settlement agencies becoming SAHs, and through attempts to increase collaboration between settlement services and sponsors to help refugees access government-funded settlement services. As of 2018, six settlement agencies welcoming GARs were also SAHs, ${ }^{374}$ and they received 363 spaces combined to sponsor refugees under the PSR program in $2018 .{ }^{375}$ Refugees beyond GARs are already accessing settlement services. Among Syrian refugees, almost 100\% of BVORs and 93\% of PSRs accessed at least one settlement service, particularly language assessment and training. ${ }^{376}$ However, IRCC noted early on during the Syrian initiative that "limited awareness of settlement supports and services on the part of new sponsors, and lack of

\footnotetext{
372 Evaluation Division, "Evaluation of the Syrian Initiative," 26.

${ }^{373}$ Evaluation Division, "Evaluation of the Settlement Program," 54.

374 IRCC, "Find Help to Adjust - Refugees"; IRCC, "Private Sponsorship of Refugees Program Sponsorship Agreement Holders."

${ }^{375}$ Calculated by the author based on IRCC, "Memorandum to the Minister: 2018 Sponsorship Agreement Holder Allocation Figures,” February 21, 2018, F-978154, obtained under an Access to Information request, A-2018-07384.

${ }^{376}$ Evaluation Division, "Syrian Outcomes Report” (Ottawa: Immigration, Refugees and Citizenship Canada, June 2019), 6, https://www.canada.ca/content/dam/ircc/documents/pdf/english/corporate/reportsstatistics/evaluations/syria-outcomes-report-may-2019.pdf.
} 
clarity around roles and responsibilities of sponsors to connect refugees to services, is increasingly a barrier for [PSRs] in accessing settlement services." ${ }^{377}$

In response to this challenge, the Allies in Refugee Integration project is "an IRCCfunded project that aims to increase and strengthen collaboration between settlement service providers and refugee sponsorship groups in Ontario, and ultimately improve settlement outcomes of privately sponsored refugees." ${ }^{378}$ In an interview, two representatives from the project explained the starting premise:

One thing we really emphasize in this project is that in order to settle well, sponsored newcomers and probably most newcomers do well with an integrated approach to settlement, which includes both those formal, professional supports like you get from a settlement worker and also more informal, community-based supports that sponsors can offer and other players as well...you need both, and you need them to work more seamlessly together. I think that's what we believe...So we're trying to prove that, and we are trying to prove how to do that. ${ }^{379}$

Several other interview participants noted the benefits of a settlement support model including both settlement services and sponsors and expressed great interest in the project. One SAH that was also a settlement agency explained that they host a mandatory intake meeting with sponsors, sponsored refugees and settlement workers to clarify roles and explain available services, though noted that beyond this initial meeting sometimes

${ }^{377}$ IRCC, "Memorandum to the Assistant Deputy Minister: Top Policy and Program Issues: Resettlement/Settlement and Integration of Syrian Refugees," 2016, obtained under Access to Information request A-2016-37379.

378 OCASI, “Allies in Refugee Integration,” OCASI: Ontario Council of Agencies Serving Immigrants, accessed March 29, 2020, https://ocasi.org/allies-refugee-integration; Michelle Ball, "Working Together to Support Sponsored Refugees: A Literature Review on Best Practices in Settlement-Sponsor Collaboration" (Allies in Refugee Integration, August 2019), https://www.ocasi.org/sites/default/files/working-together-tosupport-sponsored-refugees-literature-review_1.pdf; Allies in Refugee Integration, "Promoting SettlementSponsor Collaboration: Best Practices Report” (Allies for Refugee Integration, April 2019), https://www.ocasi.org/sites/default/files/promoting-settlement-sponsor-collaboration-best-practicesreport.pdf.

${ }^{379}$ Staff from the Allies in Refugee Integration Project, interview with author, February 18, 2020. 
newcomers do not access settlement services again. ${ }^{380}$ Two pilots are currently testing hosting knowledge exchange events, where settlement service providers and sponsors are able to meet each other, and assigning sponsors to a settlement worker prior to arrival, then pursuing a three-way case management model after arrival "where the newcomer also has control and impact over their settlement goals, but keeping the sponsor in the loop." ${ }^{381}$

The Allies in Integration representatives emphasized that the goal of the program is not to make private sponsorship more "public," but instead to enable private sponsors and sponsored refugees to benefit from public services that are already available to them. ${ }^{382}$ They observed that portraying resettlement as a public-private dichotomy can actually be harmful, keeping sponsored refugees from accessing settlement services for which they are eligible as permanent residents:

When we make that difference private versus public, we then create this idea that privately sponsored refugees should not be accessing services, which is actually incorrect...However, the way the government has described the program in their own training materials and their own promotional materials and documents and even the application form, and the way the media is portraying it, and the way general society is talking about it, people are then given that impression...The way things are set up right now, it is seen as a failure for a sponsor or privately sponsored refugees to go access specific services, because people feel that I have a private sponsor, you should be able to do all of this, but that's incorrect and also unrealistic to expect an everyday Canadian who has a full-time job to be able to help with all of the things when it's a very complicated system to navigate...We always say it's not a failure, it's not a bad thing, it is your right, it is important, you need to go see services, they have the expertise. And the other thing is a lot of people then think if they access services their sponsors will be in trouble, or the refugee will be in trouble because they accessed something, and then the government is going to say 'that's not

\footnotetext{
${ }^{380}$ Sabine Lehr (Private Sponsorship of Refugees Manager, Inter-Cultural Association of Greater Victoria), interview with author, January 24, 2020.

${ }^{381}$ Staff from the Allies in Refugee Integration Project, interview with author, February 18, 2020.

382 Ibid.
} 
okay, why did you do that.' So there's a whole system of fear and uncertainty that has been created by this lack of clarity. ${ }^{383}$

As mentioned in chapter 2, one reason that feminist scholars see the public-private dichotomy as problematic is that portraying care as belonging within the private sphere places the full burden of care on private actors, particularly women, and prevents investment in and access to high-quality public care. Within the resettlement system, portraying sponsorship as private is discouraging sponsored refugees from accessing public settlement services, which can help in their integration, as well as stigmatizing sponsors who refer refugees to settlement services for some of their care needs.

\subsection{The Government-Sponsor Relationship}

Interview participants had various ways to describe the government-sponsor relationship, from having "ups and downs" over the 40 years of the program, ${ }^{384}$ to a "relationship of mutual dependence" but one that has "always been strained." ${ }^{385}$ Similar to the relationship between the government and settlement agencies described in the previous chapter, the relationship between the government and sponsors is hierarchical, with the government holding more power. Someone who was on the original NGO-Government Committee on private sponsorship explained that: "the government tends to dominate, and the first thing they wanted to use the committee for was to design a new sponsorship agreement, and usually the government wins because they own the legislation, they own the regulations, and they've got the money to bring to the table." 386

\footnotetext{
${ }^{383}$ Staff from the Allies in Refugee Integration Project, interview with author, February 18, 2020.

${ }^{384}$ Brian Dyck (National Migration and Resettlement Coordinator, Mennonite Central Committee Canada), interview with author, December 13, 2019.

${ }^{385}$ Sabine Lehr (Private Sponsorship of Refugees Manager, Inter-Cultural Association of Greater Victoria), interview with author, January 24, 2020.

${ }^{386}$ Anonymous, interview with author, 2020.
} 
However, care ethics suggests that even though some actors hold more power in a relation of care, vulnerability and interdependence are mutual. One interview participant admitted that "we need one another whether we like it or not...At the end of the day, without the activity of the sponsors on the ground, the government is not going to land 20,000 people and that is a huge risk on the part of the government, the government relying to such an extent on the activity of volunteers to fulfill its immigration landing targets."”387 While sponsors hold less power than the government and must accept government policy changes, the government is also dependent on settlement agencies and sponsors to implement its resettlement program and reach sponsorship targets.

\subsection{Monitoring Private Sponsorship}

Currently, one of the contentious issues between the government and sponsors is the new monitoring framework under the government's Quality Assurance Initiative. One participant described how the government shifted from hardly monitoring the program to extensive monitoring, with a full government unit in Toronto dedicated to monitoring the PSR program. ${ }^{388}$ Sponsors are advised to document in detail both their financial and their settlement support, and be able to produce those documents to prove support if IRCC audits the case, such as copies of cheques, receipts for items purchased, and copies of the refugee's documents that the sponsor helped obtain. ${ }^{389}$

Insufficient monitoring of the private sponsorship program was first identified as a major issue in a 2007 program evaluation, ${ }^{390}$ (although the Canadian Council for Refugees

\footnotetext{
387 Anonymous, interview with author, 2020.

388 Sabine Lehr (Private Sponsorship of Refugees Manager, Inter-Cultural Association of Greater Victoria), interview with author, January 24, 2020.

389 RSTP Bulletin, February 15, 2019.

${ }^{390}$ Evaluation Division, "Evaluation of the Resettlement Programs," 12.
} 
suggested that monitoring was under-reported given methodological issues with the evaluation). ${ }^{391}$ The 2016 Evaluation of the resettlement programs noted that monitoring had not yet been addressed. ${ }^{392}$ Although officially local IRCC staff were responsible for monitoring sponsors, there was infrequent monitoring in practice, no formal monitoring mechanism, limited knowledge about what to do in case of a sponsorship breakdown, and no requirement to make sponsored refugees aware of the settlement plan and sponsor responsibilities to fulfill it. ${ }^{393}$ The evaluation recognized a "need to adopt a risk-based approach to monitoring to ensure PSRs are not left vulnerable in their first year." 394 The 2016 evaluation of the Syrian initiative found that some PSRs were paying to be sponsored (which is against the regulations), and some sponsors were not providing adequate support. ${ }^{395}$ Returning to care ethics and some of the literature on sponsor-sponsored relations, it is important to recognize the power hierarchy inherent in the sponsorship relationship and the potential for abuse, particularly as PSRs dependent on their sponsors for financial support and for support in navigating community resources.

In response to these concerns, the government introduced a new monitoring framework. A Memorandum to the Minister ${ }^{396}$ describes its rationale:

With the significant growth in the Private Sponsorship of Refugee Program in recent years, there is an identified need to move from a reactive approach to dealing with concerns as they are brought to the Department's attention to a proactive approach to ensure the Program's integrity, mitigate risk to the Department, and ensure the successful integration of [PSRs].

\footnotetext{
${ }^{391}$ Canadian Council for Refugees and Sponsorship Agreement Holder representatives, "Comments on Private Sponsorship of Refugees Evaluation," 8.

392 Evaluation Division, "Evaluation of the Resettlement Programs," 12.

393 Ibid., 18.

394 Ibid., 41.

395 Evaluation Division, "Evaluation of the Syrian Initiative," 28-29.

${ }^{396}$ IRCC. "Memorandum to the Minister: Private Sponsorship of Refugees Program Assurance Activities," June 1, 2018, F-992928, obtained under Access to Information request A-2018-50345.
} 
The Memorandum goes on to explain that in April 2017, the Department created a team to monitor sponsorships and follow-up on reported issues. In reviewing 380 cases, they found many issues, including "refugees paying sponsors for their full settlement support prior to arrival; refugees not receiving sufficient financial support from sponsors on arrival; refugees being coerced to work soon after arrival; and sponsors not providing adequate post-arrival support." Now, the Resettlement Services Assurance Team investigates reported cases, conducts proactive monitoring of a random sample of cases (via online questionnaires and telephone interviews), and conducts reactive monitoring of groups with reported concerns. ${ }^{397}$ This new initiative has strained relationships between the government and sponsors: "a lot of sponsors have this feeling that they are no longer trusted by the government. ${ }^{398}$ A report explains that in 2019 in a meeting with IRCC:

SAHs stated that they believe monitoring was introduced without adequate consultation. Their challenges with assurance work include an increased workload despite limited staff; an inability to prove in-kind support; the bureaucratic application of the guidelines that does not prioritize the best interests of the newcomers; and a climate of accusations and/or threats from the assurance officers. The SAHs recommended that IRCC set up a dispute resolution mechanism; respect the privacy of newcomers; create a concern matrix; and an outline of possible solutions; recognize the broad range of support including in-kind support; and recognize that PSRP is a partnership between government and civil society. ${ }^{399}$

The report recommended that "IRCC needs to study the private sponsorship ecosystem in order to structure a more appropriate assurance monitoring system." ${ }^{400}$

\footnotetext{
${ }^{397}$ Refugee Sponsorship Training Program, "PSR Post-Arrival Assurance Activities” (Refugee Sponsorship Training Program, January 7, 2020), http://www.rstp.ca/wp-content/uploads/2020/01/PSR-Post-ArrivalAssurance-Activities-Jan-2020.pdf.

${ }^{398}$ Brian Dyck (National Migration and Resettlement Coordinator, Mennonite Central Committee Canada), interview with author, December 13, 2019.

${ }^{399}$ Kaduuli, "Continuing Welcome," 13.

${ }^{400}$ Ibid., 13.
} 


\subsection{Sponsorship Agreement Holder Capacity}

While many in the sponsorship community see rising PSR numbers as a positive development, a significant concern for interview participants was the issue of SAH capacity. SAHs are faced with increasingly demanding monitoring requirements under the Quality Assurance Initiative and are being asked to sponsor BVOR and JAS cases in addition to a growing number of PSR cases. SAHs receive no government funding for staff or administration of the program, and many SAHs are exclusively volunteer organizations with no paid staff. Some interview participants complained that it was unreasonable to expect sponsors to meet these new expectations without funding: "IRCC is dictating how sponsorship should be run, but not investing in it."401 Another interview participant suggested that "it is almost like the Canadian government is trying to impose the same structure that applies in the service provider communities, for settlement agencies and RAP providing agencies, to a sponsorship community that is entirely unfunded." $" 402$

As table 2 shows, SAHs vary greatly in terms of the size of their PSR program. Some individual SAHs have larger programs than states. Seven of the twenty states that welcomed UNHCR-referred refugees in 2018 resettled less than 100 people. ${ }^{403}$ Some of the variation in program size is related to whether a SAH has paid staff. About $10 \%$ of SAHs in Canada are doing the majority of BVOR sponsorship, and most of these SAHs have paid staff. ${ }^{404}$

\footnotetext{
401 Anonymous, interview with author, December 4, 2019.

${ }^{402}$ Sabine Lehr (Private Sponsorship of Refugees Manager, Inter-Cultural Association of Greater Victoria), interview with author, January 24, 2020.

${ }^{403}$ UNHCR, "Resettlement Data Finder."

${ }^{404}$ Emilie Coyle (Former Director of National Programs, Refugee Hub), interview with author, December $16,2019$.
} 
Table 2 Sponsorship Agreement Holders by Size of PSR Program ${ }^{405}$

\begin{tabular}{ll}
\hline $\begin{array}{l}\text { Number of PSR cap spaces allocated in } \\
\mathbf{2 0 1 8}\end{array}$ & $\begin{array}{l}\text { Number of Sponsorship Agreement } \\
\text { Holders }\end{array}$ \\
\hline Less than 10 & 12 \\
\hline $\mathbf{1 0 - 1 9}$ & 10 \\
\hline $\mathbf{2 0 - 2 9}$ & 15 \\
\hline $\mathbf{3 0 - 4 9}$ & 16 \\
\hline $\mathbf{5 0 - 9 9}$ & 28 \\
\hline $\mathbf{1 0 0 - 1 9 9}$ & 16 \\
\hline $\mathbf{2 0 0 - 2 9 9}$ & 7 \\
\hline Over 300 & 2 \\
\hline TOTAL & 106 \\
\hline
\end{tabular}

As one SAH explained, the people who are "managing and coordinating these programs have to have a level of professional knowledge, which depending on how you operate your program, can be quite intensive [involving] numerous different skillsets including accounting, dispute resolution, communication, public outreach, [and] promotion." ${ }^{406}$ As a potential solution to capacity challenges, it was suggested that the government provide some financial support to SAHs in order to manage sponsorships according to government expectations, with a positive model being the 2019 BVOR fund which offered $\$ 5,000$ in funding to SAHs for each BVOR case to go toward administrative support. ${ }^{407}$ In the case of one SAH that took on 4 BVOR cases, this money amounted to $\$ 20,000$, which was a significant contribution toward staff salary in an unfunded program, while other SAHs who were completely volunteer-based were able to hire part-time staff. ${ }^{408}$ Given that the BVOR

\footnotetext{
${ }^{405}$ Calculated by the author based on IRCC, "Memorandum to the Minister: 2018 Sponsorship Agreement Holder Allocation Figures," 21 February 2018, F-978154, obtained under Access to Information request A2018-07384.

${ }^{406}$ Sabine Lehr (Private Sponsorship of Refugees Manager, Inter-Cultural Association of Greater Victoria), interview with author, January 24, 2020.

${ }^{407}$ Ibid.

${ }^{408}$ Ibid.
} 
fund was time-limited, it was suggested that government funding would offer a more sustainable solution to the challenges of SAH capacity.

Given limited SAH capacity, interview participants expressed concerns about how the monitoring framework would impact the future of the program. One person supported the need for monitoring, but explained that it poses a "challenge to make sure that IRCC feels like the program has integrity and individual settlements have integrity, but not in a way that is so onerous for the sponsors that they say I'm just going to leave this or I just can't do this anymore. ${ }^{" 409} \mathrm{He}$ also expressed the concern that if sponsors do not feel they can manage the system, they may not meet the 20,000 refugees per year target. ${ }^{410}$

\subsection{A "Caring" Approach? Government Bureaucracy versus Sponsor Care}

The new sponsorship monitoring framework has revealed a contrast between government and sponsor approaches. Participants spoke about a rules-based framework, that did not always fit well with relations of care or cultural realities on the ground:

There are numerous issues where the understandings differ between a government entity that works according to rules and regulations and a private sponsorship community that basically works out of a humanitarian motivation and initiative. There is kind of a cultural clash in terms of how these different groups in society are seeing that work and consequently how they are carrying out that work. We are just now in the middle of trying to have these conversations and come to some kind of common denominator, where the government understands better where civil society is coming from and even how civil society operates on the ground, and where civil society needs to understand better what the government's expectations are and under what kind of frameworks the government works... So that is I think part of the growing pains of the program... One of the issues is that fundamentally, many parts of the sponsorship community see the program very much as saving people's relatives who find themselves in situations overseas to come to Canada. The government sees the program very much as part of its larger resettlement programs and has now applied the same

\footnotetext{
409 Brian Dyck (National Migration and Resettlement Coordinator, Mennonite Central Committee Canada), interview with author, December 13, 2019.

410 Ibid.
} 
rules that apply to GARs also to PSRs, even though we know they come into a very different environment. ${ }^{411}$

Another person suggested that "An oversimplification of the situation is that IRCC is focused on quality, and sponsors tend to be focused on quantity...Sponsors are just saying 'how can we get more people here?' and IRCC is saying 'you have to do it right'."412 One interview participant suggested that with the IRCC Quality Assurance staff there was "no heart there" in terms of training and perspective. ${ }^{413}$

Several participants spoke of the challenges of applying a professionalized monitoring framework to a program that depends highly on family relationships, particularly in light of different cultural norms. One participant suggested that "IRCC is insisting you do these things, even though some clients are well cared for by family and don't need support." ${ }^{\prime 14}$ Another person spoke of the challenge of applying the rules in the context of family relationships and of documenting support given to family members. ${ }^{415}$ For example, even if a refugee lives with and eats all meals with a relative who is a cosponsor, the rules only allow sponsors to deduct up to $50 \%$ for food provided in-kind. As another example, adults over 18 are entitled to separate financial allowances. However, in many cultures a 19-year-old unmarried daughter will live at home. As a result "until age 17 and 364 days, this person is treated as a child... but the minute they turn 18 they have other rights, and so now you as the sponsor, even though it's just another day...you have to treat that person differently from a financial perspective. There are these issues that we

\footnotetext{
411 Anonymous, interview with author, 2020.

412 Brian Dyck (National Migration and Resettlement Coordinator, Mennonite Central Committee Canada), interview with author, December 13, 2019.

${ }^{413}$ Anonymous, interview with author, December 4, 2019.

414 Ibid.

415 Sabine Lehr (Private Sponsorship of Refugees Manager, Inter-Cultural Association of Greater Victoria), interview with author, January 24, 2020.
} 
know on the ground...but to make someone in Ottawa understand is a more difficult task." ${ }^{\prime 46}$ Another person commented on the influence of cultural differences, contrasting IRCC's focus on individual autonomy with an approach of many sponsors who are not Canadian by birth where "the community is the centre, not the individual" and the group will "pitch in together to take care of this person" with less focus on individual rights. ${ }^{417}$

\subsection{Conclusion}

In recent years, private sponsorship has grown significantly. At the same time, the government has become more involved: processing more cases, monitoring sponsors more intensively, and promoting government-funded settlement services. Does this involvement call for greater financial responsibility? Many would like to see more government investment, such as building SAH capacity by funding paid staff. Beyond strengthening the program, government investment may have broader benefits. The Global Refugee Sponsorship Initiative has repeatedly emphasized the societal benefits of refugee sponsorship. ${ }^{418}$ Representatives from the Allies in Refuge Integration project suggested:

It actually benefits the public, and the public sector, and the government to invest in private sponsorship, because the return is more engaged citizens, more educated citizens, citizens who can navigate the services in their communities better and understand better, so that when the government has to go and pass any new laws, or to improve anything in the system you have support from them. ${ }^{419}$

As private sponsorship continues to resettle 20,000 refugees each year, the meaning of "private" will continue to be negotiated among the many actors involved in the program.

\footnotetext{
416 Sabine Lehr (Private Sponsorship of Refugees Manager, Inter-Cultural Association of Greater Victoria), interview with author, January 24, 2020.

${ }^{417}$ Brian Dyck (National Migration and Resettlement Coordinator, Mennonite Central Committee Canada), interview with author, December 13, 2019.

418 Global Refugee Sponsorship Initiative, "Who We Are."

${ }^{419}$ Staff from the Allies in Refugee Integration Project, interview with author, February 18, 2020.
} 


\section{Conclusion}

This thesis asked critical questions about the relationships between public and private actors in Canada's resettlement system. How do we understand and explain the complex and sometimes contradictory relationships between state and non-state actors? Is there a clear distinction between the role of public and private actors? What does understanding these relationships reveal about the functioning of Canada's refugee resettlement process?

It has argued that all resettlement programs in Canada are public-private partnerships that combine contributions from the government, sponsors and volunteers to care for refugees. Unlike some portrayals of resettlement that create a dichotomy between state-led and private resettlement, in practice there is overlap between categories and interdependence between public and private actors. By making care visible, this thesis shows how institutional categories hide care arrangements on the ground and simplify the complexity of living relations. Finally, by critically engaging with power hierarchies, it has shown how the government holds power over settlement agencies, sponsors and refugees, but these actors are not without agency or power to shape policy and practice.

Chapter 1 looked at the literature on private sponsorship and the history of the resettlement system, showing that tensions between public and private actors have been present since sponsorship's beginnings, yet an institutional history simplifies this complex relationship and sets up a public-private dichotomy. Chapter 2 introduced care ethics, questioning the gendered public-private dichotomy, centering mutual dependency and vulnerability, and presenting a nuanced understanding of power. Chapter 3 revealed that the "Government-Assisted Refugee" program is not a unified category, and is not an entirely public program given the extensive involvement of NGO settlement agencies, 
BVOR and JAS sponsors, and volunteers. Chapter 4 revealed that private sponsorship relies on government involvement, and found that while increased government involvement in terms of monitoring is contentious, there is a desire for increased government involvement in terms of capacity-building.

\subsection{Implications for the GAR-PSR Debate}

As mentioned in chapter 1 , there is a growing research effort to compare integration outcomes between GARs and PSRs. However, this thesis highlights some issues in the debate over whether GAR or PSR is "better." First, as chapters 3 and 4 explain, these programs respond to two different commitments: one to resettle UNHCR-referred refugees based on need and protection principles, and the other to help refugees in Canada reunite with their relatives. As the struggle to recruit sponsors for BVOR and JAS demonstrates, even if sponsorship is deemed the superior model, it will never replace the GAR program for UNHCR-referred refugees. Simply put, there are not enough sponsors willing and able to care for strangers to sustain such a high level of resettlement through sponsorship alone.

Second, the debate tends to present the GAR and PSR programs as opposites, whereas this thesis revealed they overlap in practice. Trying to determine whether one model is "better" may detract from attempts to learn from the strengths of each model. Innovative models for supporting GARs, such as welcome teams inspired by sponsorship, and efforts to help sponsored refugees access settlement services, are two examples of how the different resettlement programs may learn from each other rather than compete.

As chapter 3 outlined, the GAR program is not a single integration model, but actually a broad category that encompasses a variety of care arrangements. In a research study, a refugee sponsored through JAS, a refugee supported by a welcome team, and a 
refugee with no connection to volunteers would all count as GARs. If the goal of research is to compare the GAR and PSR integration models, it can no longer assume that GAR represents one unified model for integration support. It could be useful to document, research and compare the various care arrangements that support GARs, such as Welcome Teams and volunteer matching through Community Connections. The Together Project has suggested to "conduct public consultations with grassroots volunteer initiatives to understand best practices and develop an authoritative institutional memory of the types of volunteer initiatives which emerged from the period of Syrian refugee resettlement. ${ }^{\circledR 420}$

In the case of the JAS program, even statistics on the number of cases are not publicly available. It has so far been excluded from government evaluations and largely excluded from research, with the exception being a few studies of the Kosovar sponsoring experience in $1999 .{ }^{421}$ This thesis offered preliminary observations about JAS profiles that merit further study, including demographic trends and the geographic concentration of referrals. A useful direction for future research would be to investigate this program's operation and history, which could contribute to broader discussions about supporting refugees with special needs and engaging civil society to sponsor strangers.

The GAR-PSR debate also informs Canada's efforts to promote sponsorship to other countries. Representatives of the GRSI have argued that a community sponsorship

\footnotetext{
${ }^{420}$ Smith, Hadžiristić, and Alipour, "Filling the Gap," 11.

${ }^{421}$ Derwing and Mulder, "The Kosovar Sponsoring Experience in Northern Alberta"; Kathy Sherrell and Jennifer Hyndman, "Sharing the Wealth, Spreading the 'Burden'? The Settlement of Kosovar Refugees in Smaller British Columbia Cities," Canadian Ethnic Studies 37, no. 3 (2005): 76-96; Baha. Abu-Laban, Lessons Learned: An Evaluation of Northern Alberta's Experience with Kosovar Refugees: A Study Prepared for Citizenship and Immigration Canada (Edmonton: Prairie Centre of Excellence for Research on Immigration and Integration and Population Research Laboratory, University of Alberta, 2001).
} 
model addresses the "problem" of over-professionalization. ${ }^{422}$ Drawing on research from the United States about non-profits, they suggest that over-professionalization "alienates people from the helping relationships they could establish with their neighbors and kin." ${ }^{423}$ In contrast, they argue: "the deep engagement and high degree of responsibility undertaken by individual refugee sponsors repositions newcomers from vulnerable outsiders whom private individuals watch fail or succeed, to partners in a project of collective interests: the newcomers' success is inherently also the sponsors' success." ${ }^{24}$

This argument may have unintended consequences. First, promoting sponsorship by critiquing GAR does not fully recognize the complementary roles of the programs. Second, it sets up a dichotomy that is more fluid in practice. On the one hand, the professionalized GAR model has space for volunteers to be "partners" in settlement, especially through JAS and welcome team models. On the other hand, the PSR model is not the opposite of professionalization. PSRs benefit from the services of settlement agencies, and the Allies in Integration Project asserts that refugees do best with a model that combines the professional support of settlement agencies with the informal, community-based support of sponsors. Third, criticizing the GAR program may reduce public support for and engagement in existing government resettlement programs, which may further concerns around the privatization of resettlement.

\footnotetext{
422 Jennifer Bond and Ania Kwadrans, "Resettling Refugees through Community Sponsorship: A Revolutionary Operational Approach Built on Traditional Legal Infrastructure," Refuge: Canada's Journal on Refugees 35, no. 2 (June 5, 2019): 88.

${ }^{423}$ Lester M. Salamon, "The Resilient Sector: The State of the Nonprofit America," in The State of Nonprofit America, ed. Lester M. Salamon (Washington: Brookings Institution Press, 2002), 30.

${ }^{424}$ Bond and Kwadrans, "Resettling Refugees through Community Sponsorship," 88.
} 


\subsection{Government Support for Volunteers and Sponsors}

The recognition that all forms of resettlement require both government and private support, and that the government and sponsors are mutually dependent, should encourage greater cooperation, instead of competition that places one group of refugees over another. All programs could benefit from increased government support and increased community engagement. On the one hand, the government needs more help from the sponsorship and volunteer community in supporting UNHCR-selected refugees, through JAS, BVOR and volunteer programs. While increasing the number of GARs is a laudable goal, there are capacity concerns, and care is central to this discussion. Innovative practices such as welcome teams may continue to play a role, alongside longstanding models like JAS.

Currently, volunteer initiatives are sometimes operating behind the scenes playing a gap-filling role. It could be useful for the government and settlement agencies to more proactively engage with volunteers and volunteer initiatives, recognizing their role as partners in resettlement. In practice, that may include small amounts of government funding for volunteer initiatives, like the case of Operation Ezra. Various reports have recommended funding volunteer coordinator or sponsor liaison positions within settlement agencies. ${ }^{425}$ The coordinator positions for the Host Program and volunteer coordinator positions during the Syrian initiative offer valuable precedents. Other ways to increase capacity - particularly increased funding to settlement agencies and new destination communities for GARs - would both be complementary to higher community engagement.

On the other hand, the sponsorship community needs help from the government to build the capacity to sustain high levels of private sponsorship and to participate in BVOR

\footnotetext{
${ }^{425}$ Fratzke, "Volunteers and Sponsors"; Smith, Hadžiristić, and Alipour, "Filling the Gap."
} 
and JAS, particularly for SAHs in light of new monitoring requirements. Capacity-building may include training and financial support. Investing in SAH capacity could enable SAHs to more effectively implement the new monitoring framework, and may also lessen resistance to it. The Allies in Refugee Integration project also suggests promising practices in terms of connecting sponsored refugees with settlement services.

\subsection{Principles for Cooperation: Listening, Responsiveness and Attentiveness}

In the context of promoting cooperation in resettlement, the care ethics principles of attentiveness, listening and responsiveness offer useful guidance. This thesis has noted some concerns that the government does not always listen to or understand the perspectives of refugees, settlement agencies or sponsors, so listening will be critical to future effective partnership. The care ethics principle of responsiveness places the needs of the one receiving care at the forefront of an evaluation of any care relation and supports the involvement of those who are receiving care in making decisions. In particular, involving refugees in defining the goals of integration and in determining the best care arrangements to achieve these goals would be helpful. So far, some research has looked at refugee perspectives and experiences of the different resettlement programs, ${ }^{426}$ and expanding this work could be valuable. As refugees are also caregivers, supporting refugees in fulfilling their care responsibilities will continue to be important.

\footnotetext{
${ }^{426}$ Agrawal, "Canadian Refugee Sponsorship Programs"; Nimo Bokore, "Refugee Resettlement: Understanding the Refugee Experience in the Canadian Context," in Syrian Refugee Reflections on Canada's Sponsorship Programs, ed. B Sethi, S Guruge, and R Csiernik (Palgrave Macmillan, Accepted, In Progress).
} 


\subsection{Implications for Promoting Sponsorship to the World}

In states with pre-existing resettlement programs, it may be useful to consider how NGOs, families, volunteers, and informal networks are already involved in care arrangements for resettled refugees, instead of taking a state-based view of resettlement that sees governments as the only actors supporting resettled refugees. Indeed, comparative research has shown that NGOs and volunteers are actively involved in resettlement in several European countries, including through matching programs. ${ }^{427}$ When the Global Refugee Sponsorship Initiative was envisioned, it was thought that Latin America would be a good place for sponsorship because "we were dealing with states who didn't have the strength or financial deep pockets that Canada does...but they do have active civil societies... it was an interesting model to show more can be done as they struggle to try to be resettlement

countries. ${ }^{\prime 28}$ Argentina has started a program, but most new programs are in Europe where state-led resettlement programs already exist. Promoting sponsorship for states with limited capacity holds potential, but as chapter 4 explained, it is important not to underestimate the level of state commitment in a private sponsorship program, from processing to settlement services to monitoring. Any new program is likely to require both significant government investment and significant community involvement to be successful, whether the program is envisioned as community sponsorship, government resettlement or a public-private partnership.

\footnotetext{
${ }^{427}$ van Selm, "Public-Private Partnerships in Refugee Resettlement."

${ }^{428}$ Michael Casasola (Senior Resettlement Officer, UNHCR Canada), interview with author, February 3 , 2020 .
} 


\subsection{Understanding the Identities of Caregivers}

As noted in Chapter 2, there is limited understanding of who is involved in caring for refugees, and how gender, race and class influence these relationships. Besides an observation that a sponsor's culture influences care for refugees, this project contributes little to this discussion. Future research could apply intersectional analysis to sponsors, volunteers and settlement workers, including religious identity given the prominent roles of religious groups, age because initial research has shown that many sponsors are retired seniors, and immigrant/refugee background.

\subsection{The Future of Resettlement: COVID-19 and Beyond}

The COVID-19 pandemic has suspended resettlement departures. Since the interviews for this thesis were conducted prior to the start of the pandemic in Canada, it would be problematic to extrapolate to draw conclusions about resettlement post-pandemic. ${ }^{429}$ However, questions regarding the distribution of responsibilities between public and private actors will remain salient. If the government attempts to "catch up" on targets by resettling the same number of refugees but in a shorter period of time, it will present capacity challenges and require significant cooperation. Settlement agencies may need volunteer support to resettle a large number of refugees in a short period of time. The pandemic also has financial implications and prospective sponsors may need financial or other incentives to participate. Although the future remains uncertain, public and private actors will continue to play essential roles in welcoming refugees in the years to come.

\footnotetext{
${ }^{429}$ For reflections on the impact of COVD-19 on the future of sponsorship, see Jennifer Bond, Giulio Di Blasi, and Ania Kwadrans, "The Future of Community Sponsorship of Refugees: Meeting COVID-19's Challenges," Kaldor Centre for International Refugee Law (blog), May 25, 2020, https://www.kaldorcentre.unsw.edu.au/publication/future-community-sponsorship-refugees-meeting-covid19 s-challenges.
} 


\section{Appendices}

\section{Appendix A Timeline of Refugee Resettlement in Canada}

\begin{tabular}{|c|c|}
\hline $1923-1930$ & $\begin{array}{l}\text { Mennonite Central Committee resettles over 21,000 Mennonites from the } \\
\text { Soviet Union to Canada }\end{array}$ \\
\hline $1947-1952$ & $\begin{array}{l}250,000 \text { displaced persons from Central and Eastern Europe resettle to } \\
\text { Canada through the "bulk labour" and the "close relatives" programs } \\
\text { (around } 60,000 \text { through sponsorship) }\end{array}$ \\
\hline 1956 & $\begin{array}{l}37,000 \text { Hungarian refugees resettle to Canada through a sponsorship } \\
\text { program }\end{array}$ \\
\hline 1967 & $\begin{array}{l}\text { - Canada signs the } 1951 \text { Refugee Convention and } 1967 \text { Protocol } \\
\text { - Removal of race, religion and nationality as factors in the } \\
\text { selection of immigrants }\end{array}$ \\
\hline 1971 & Government adopts policy of multiculturalism \\
\hline 1976 & Immigration Act passed, includes a provision for private sponsorship \\
\hline 1978 & Immigration Act comes into force \\
\hline 1979 & $\begin{array}{l}\text { - Formal launch of Canada's PSR program, GAR and JAS } \\
\text { programs } \\
\text { - } \quad \text { First sponsorship agreements signed } \\
\text { - Beginning of the Indochinese resettlement initiative }\end{array}$ \\
\hline 1980-1981 & Continuation of the Indochinese resettlement initiative \\
\hline 1984 & $\begin{array}{l}\text { Host Program begins as pilot, matching newly-arrived refugees with } \\
\text { Canadian individuals and families }\end{array}$ \\
\hline 1985 & $\begin{array}{l}\text { - Canadian Multiculturalism Act passed } \\
\text { - Government begins funding NGOs as settlement provider } \\
\text { organizations }\end{array}$ \\
\hline 1986 & $\begin{array}{l}\text { UNHCR awards the Nansen Refugee Award to "the people of Canada" } \\
\text { for their work in resettling Indochinese refugees }\end{array}$ \\
\hline 1990 & $\begin{array}{l}\text { - Federal Integration Strategy adopts "two-way street" approach to } \\
\text { integration } \\
\text { - Host Program becomes permanent and expands to other } \\
\text { newcomers }\end{array}$ \\
\hline 1994-1998 & $\begin{array}{l}\text { Project FOCUS Afghanistan resettles 1,800 Afghan Ismaili refugees } \\
\text { under a 3/9 model }\end{array}$ \\
\hline $1995-1996$ & $\begin{array}{l}\text { 3/9 Refugee Sponsorship Programme for refugees from former } \\
\text { Yugoslavia }\end{array}$ \\
\hline 1998 & $\begin{array}{l}\text { Creation of the Resettlement Assistance Program, transfer of } \\
\text { responsibility for GAR integration to NGOs }\end{array}$ \\
\hline 1999 & $\begin{array}{l}\text { Emergency evacuation of over } 5500 \text { Kosovar refugees by the Canadian } \\
\text { Forces, JAS sponsorship. }\end{array}$ \\
\hline 2001 & - $4 / 8$ sponsorship program for refugees from Sierra Leone \\
\hline
\end{tabular}




\begin{tabular}{|c|c|}
\hline & $\begin{array}{l}\text { Parliament passes the Immigration and Refugee Protection Act, } \\
\text { which shifts refugee selection criteria to place more emphasis on } \\
\text { protection over ability to establish in Canada }\end{array}$ \\
\hline 2002 & $\begin{array}{l}\text { - Immigration and Refugee Protection Act comes into force } \\
\text { - Canada recognizes UNHCR's Agenda for Protection }\end{array}$ \\
\hline 2008 & $\begin{array}{l}\text { New model for settlement services ends the Host Program and replaces it } \\
\text { with Community Connections }\end{array}$ \\
\hline 2011 & 3/9 sponsorship programs for Iraqi and LGBTQ refugees created \\
\hline 2012 & $\begin{array}{l}\text { - Government cuts to the Interim Federal Health Program } \\
\text { - Caps introduced on the number of applications SAHs can submit }\end{array}$ \\
\hline 2013 & Launch of the Blended Visa Office-Referred program \\
\hline $\begin{array}{l}\text { October } \\
2015\end{array}$ & $\begin{array}{l}\text { Liberal majority government elected, after a campaign promise to resettle } \\
25,000 \text { Syrian refugees }\end{array}$ \\
\hline $\begin{array}{l}\text { November } \\
2015\end{array}$ & Beginning of Operation Syrian Refugees \\
\hline $\begin{array}{l}\text { February } \\
2016\end{array}$ & Canada reaches the target of 25,000 Syrian refugees \\
\hline April 2016 & $\begin{array}{l}\text { Cuts to Interim Federal Health program reversed, full coverage for PSRs } \\
\text { restored }\end{array}$ \\
\hline $\begin{array}{l}\text { October } \\
2016\end{array}$ & $\begin{array}{l}\text { House of Commons motion to resettle 1,200 Yazidis or survivors of } \\
\text { Daesh by the end of } 2017\end{array}$ \\
\hline $\begin{array}{l}\text { December } \\
2016\end{array}$ & Launch of the Global Refugee Sponsorship Initiative \\
\hline 2017 & Arrival of Yazidi refugees \\
\hline 2018 & $\begin{array}{l}\text { - Canada signs the Global Compact on Refugees } \\
\text { - First year of the BVOR fund }\end{array}$ \\
\hline 2019 & $\begin{array}{l}\text { - Canada celebrates } 40 \text { years of private sponsorship } \\
\text { - Second year of the BVOR fund }\end{array}$ \\
\hline
\end{tabular}




\section{Appendix B Semi-Structured Interview Guide}

[Note: In semi-structured interviews, the interview guide offers broad questions and themes, and the researcher asks more specific questions based on participant responses and based on the specific expertise of the participant. Not all questions will be applicable to all participants.]

\section{B.1 The participant's role}

What is your role in supporting refugee resettlement in Canada?

\section{B.2 The work of the participant's organization}

What is the role of your organization in supporting refugee resettlement in Canada? Does your organization participate in or support Private Sponsorships? Blended VisaOffice Referred sponsorships? Joint Assistance Sponsorships? Why or why not? What is your role in each program and what kinds of support do you provide in each case?

\section{B.3 The purpose of resettlement}

What do you think is the purpose of resettlement? What do you think is the role or purpose of each of the resettlement programs? What do you think the different programs achieve? How have you seen refugee resettlement policy in Canada change over your time in your role? For Sponsorship Agreement Holders: What selection criteria does your Sponsorship Agreement Holder apply in selecting cases to sponsor through private sponsorship? How do you choose which Blended Visa-Office Referred or Joint Assistance Sponsorship cases to support? How do you motivate your groups to participate in sponsorship? 


\section{B.4 State responsibility}

What is the responsibility of the state/government in refugee resettlement? What is the responsibility of private sponsors in refugee resettlement? Do you think that the government is fulfilling its responsibility? How do the government and sponsors share responsibility in each of the resettlement programs? How would you describe the relationship between the government and private sponsors? How do you respond to criticisms that the government is shifting its responsibility to private sponsors? How would you describe the relationship between service provider organizations and the government? Between service providers and sponsors?

\section{B.5 Final questions}

Do you have any questions for me? Is there anything you would like to add?

Is there anyone else who you would suggest that I interview? (If yes, I would appreciate if you would pass along the invitation email to them and ask them to contact me.) 


\section{Appendix C List of IRCC Evaluations Consulted}

1. Syrian Outcomes Report. 2019.

2. Evaluation of the Settlement Program. 2017.

3. Rapid Impact Evaluation of the Syrian Refugee Initiative. December 2016.

4. Evaluation of the Resettlement Programs (GAR, PSR, BVOR and RAP). 2016.

5. Evaluation of the Immigration Loan Program. December 2015.

6. Evaluation of Government Assisted Refugees (GAR) and Resettlement Assistance Program (RAP). 2011.

7. Evaluation of the Host Program. 2010.

8. Evaluation of the Welcoming Communities Initiative. 2010.

9. Building on a Strong Foundation for the $21^{\text {st }}$ Century: New Directions for Immigration and Refugee Policy and Legislation. 1998.

10. Evaluation of the 3/9 Refugee Sponsorship Programme Final Report. July 1996. By Jamieson, Beals, Lalonde \& Associates. Canadian Official Publications. Library and Archives Canada. 
Appendix D List of Access to Information Requests Consulted

Table 3 Access to Information Requests Related to the Syrian Refugee Initiative

\begin{tabular}{|c|c|c|c|}
\hline $\begin{array}{l}\text { Request } \\
\text { Number }\end{array}$ & Department & Description of Request & Pages \\
\hline $\begin{array}{l}\text { A-2015- } \\
24416\end{array}$ & IRCC & $\begin{array}{l}\text { All briefing notes on the Syrian refugee crisis provided } \\
\text { to immigration minister John McCallum since he was } \\
\text { sworn in on Nov. 4, } 2015 \text { to December } 18,2015 \text {. }\end{array}$ & 33 \\
\hline $\begin{array}{l}\text { A-2016- } \\
27832\end{array}$ & IRCC & $\begin{array}{l}\text { Any briefing notes (i.e. latest draft or final version), } \\
\text { policy documents or meeting minutes, generated as a } \\
\text { result of discussions between Deborah Tunis (Special } \\
\text { Coordinator for Syrian Refugee Resettlement) and } \\
\text { IRCC Regional Managers regarding, Phase } 4 \\
\text { (Welcoming in Canada) and Phase } 5 \text { (Settlement and } \\
\text { community integration). Timeframe: September 1, } 2015 \\
\text { to March 15, 2016. }\end{array}$ & 99 \\
\hline $\begin{array}{l}\text { A-2016- } \\
00242\end{array}$ & $\begin{array}{l}\text { Public } \\
\text { Safety } \\
\text { Canada }\end{array}$ & $\begin{array}{l}\text { Briefing notes, reports, and memorandums prepared for } \\
\text { the Minister and/or Assistant Deputy Ministers } \\
\text { regarding the Syrian refugee crisis. The date range for } \\
\text { this request is January } 1,2015 \text { - present. }\end{array}$ & 135 \\
\hline $\begin{array}{l}\text { A-2016- } \\
00251\end{array}$ & $\begin{array}{l}\text { Public } \\
\text { Safety } \\
\text { Canada }\end{array}$ & $\begin{array}{l}\text { Document regarding Canada's Syrian refugee } \\
\text { resettlement initiative }\end{array}$ & 211 \\
\hline $\begin{array}{l}\text { A-2016- } \\
37379\end{array}$ & IRCC & $\begin{array}{l}\text { All lessons-learned summary records created from } \\
\text { March 21, 2016 to date of receipt of this request } \\
\text { (January 9, 2017) arising from departmental and } \\
\text { interdepartmental exercises reviewing Operation Syrian } \\
\text { Refugee, including exercises conducted on March 21, } \\
\text { 2016, and on April 14, 2016. Clarification 2017-02-14: } \\
\text { Provide only the final copy of report from ASA. } \\
\text { Clarified on 2017-05-08: No emails between senior } \\
\text { officials leading up to the preparation of the report(s), }\end{array}$ & 112 \\
\hline $\begin{array}{l}\text { A-2016- } \\
44605\end{array}$ & IRCC & $\begin{array}{l}\text { Jan. 12, } 2017 \text { ministerial briefing materials under the } \\
\text { subject heading "Refugees - Resettlement," specifically } \\
\text { a) Syrian Refugees and b) Resettling Vulnerable } \\
\text { Victims of Daesh: Response to October 25, 2016, House } \\
\text { of Commons motion. - final version. }\end{array}$ & 34 \\
\hline
\end{tabular}


Table 4 Additional Access to Information Requests

\begin{tabular}{|c|c|c|c|}
\hline $\begin{array}{l}\text { Request } \\
\text { Number }\end{array}$ & Department & Description of Request & Pages \\
\hline $\begin{array}{l}\text { A-2017- } \\
01375\end{array}$ & IRCC & $\begin{array}{l}\text { All budgets, costs, briefing notes prepared for the } \\
\text { Minister regarding the effort to bring Yazidi refugees to } \\
\text { Canada. December } 2016 \text { to April } 72017 \text {, exclude media } \\
\text { monitoring. }\end{array}$ & 95 \\
\hline $\begin{array}{l}\text { A-2017- } \\
41406\end{array}$ & IRCC & $\begin{array}{l}\text { Requesting the following memo to the minister F- } \\
922553 \text { (Yazidi Population profile). }\end{array}$ & 34 \\
\hline $\begin{array}{l}\text { A-2018- } \\
09207\end{array}$ & IRCC & $\begin{array}{l}\text { F-963725 IN-ROD- " } 2017-00963725 \text { - Information } \\
\text { memorandum to the Minister that will provide an update } \\
\text { on the status of the commitment to resettle } 1200 \\
\text { survivors of Daesh before the end of } 2017\end{array}$ & 3 \\
\hline $\begin{array}{l}\text { A-2018- } \\
53310\end{array}$ & IRCC & $\begin{array}{l}\text { From January 1, } 1980 \text { to December } 11,2018 \text {, copy of } \\
\text { the following: 1) Annual reports on government } \\
\text { spending within resettlement related services for } \\
\text { refugees; and 2) Annual statistics showing the number } \\
\text { of refugees accepted through each program } \\
\text { (Government sponsored, privately sponsored, blended } \\
\text { visa). }\end{array}$ & 9 \\
\hline $\begin{array}{l}\text { A-2018- } \\
07384\end{array}$ & IRCC & $\begin{array}{l}\text { 2018-00978154 : F-978154 } 2018 \text { Sponsorship } \\
\text { Agreement Holder Allocation Figures }\end{array}$ & 6 \\
\hline $\begin{array}{l}\text { A-2018- } \\
07382\end{array}$ & IRCC & $\begin{array}{l}\text { F-974679 Next Steps for the Rainbow Refugee } \\
\text { Assistance Pilot Program }\end{array}$ & 7 \\
\hline $\begin{array}{l}\text { A-2018- } \\
50345\end{array}$ & IRCC & $\begin{array}{l}\text { IN -2018-00992928 - F-992928 - Private Sponsorship of } \\
\text { Refugees Program Assurance Activities }\end{array}$ & 3 \\
\hline $\begin{array}{l}\text { A-2018- } \\
49299\end{array}$ & IRCC & $\begin{array}{l}\text { Folder F-1004043 Update on the Blended VISA office- } \\
\text { referred Program (RAB) }\end{array}$ & 3 \\
\hline $\begin{array}{l}\text { A-2019- } \\
00368\end{array}$ & $\begin{array}{l}\text { Library and } \\
\text { Archives } \\
\text { Canada }\end{array}$ & $\begin{array}{l}\text { File name: Refugees and displaced persons - } \\
\text { Sponsorship - General - Joint assistance - Dates: [1979- } \\
\text { 1989] and [1989-1995] File: } 8630-6 \text { RG76 B-1-d } \\
\text { Finding Aid numbers: } 76-368 \text { and 76-369 }\end{array}$ & 1285 \\
\hline $\begin{array}{l}\text { A-2017- } \\
20061\end{array}$ & IRCC & $\begin{array}{l}\text { My request concerns the costs of resettled refugees } \\
\text { (state-funded and collective sponsorship). I would like } \\
\text { to obtain - the details of the fees charged - the details of } \\
\text { the transport loans including all the requested fees - the } \\
\text { statistics available for the last } 3 \text { years (including the } \\
\text { number of loans granted, the average loans) - the } \\
\text { statistics concerning repayments. Additional } \\
\text { clarifications: These are all possible costs that could be } \\
\text { charged to refugees. Not limited to, for example, } \\
\text { transportation costs for refugees, transportation costs for } \\
\text { a nurse, medical equipment rental fees, fees for IOM or } \\
\text { partners, etc. for the period of January } 1,2014 \text { as of July }\end{array}$ & 2 \\
\hline
\end{tabular}




\section{Bibliography}

Abu-Laban, Baha. "Lessons Learned: An Evaluation of Northern Alberta's Experience with Kosovar Refugees: A Study Prepared for Citizenship and Immigration Canada." Edmonton: Prairie Centre of Excellence for Research on Immigration and Integration and Population Research Laboratory, University of Alberta, 2001.

Agrawal, Sandeep Kumar. "Canadian Refugee Sponsorship Programs: Experience of Syrian Refugees in Alberta, Canada." Journal of International Migration and Integration, December 6, 2018. https://doi.org/10.1007/s12134-018-0640-7.

Allies in Refugee Integration. "Promoting Settlement-Sponsor Collaboration: Best Practices Report.” Allies for Refugee Integration, April 2019.

https://www.ocasi.org/sites/default/files/promoting-settlement-sponsorcollaboration-best-practices-report.pdf.

Ball, Michelle. "Working Together to Support Sponsored Refugees: A Literature Review on Best Practices in Settlement-Sponsor Collaboration." Allies in Refugee Integration, August 2019. https://www.ocasi.org/sites/default/files/workingtogether-to-support-sponsored-refugees-literature-review_1.pdf.

Barnes, Marian. "Beyond the Dyad: Exploring the Multidimensionality of Care." In Ethics of Care: Critical Advances in International Perspective, edited by Marian Barnes, Tula Brannelly, Lizzie Ward, and Nicki Ward, 31-44. Bristol: Policy Press, 2015.

Barnes, Marian, Tula Brannelly, Lizzie Ward, and Nicki Ward. "Introduction: The Critical Significance of Care." In Ethics of Care: Critical Advances in International Perspective, edited by Marian Barnes, Tula Brannelly, Lizzie Ward, and Nicki Ward, 3-20. Bristol: Policy Press, 2015.

Behnia, Behnam. "An Exploratory Study of Befriending Programs with Refugees." Journal of Immigrant \& Refugee Studies 5, no. 3 (September 2007): 1-19. https://doi.org/10.1300/J500v05n03 01.

_ . "Volunteering with Newcomers: The Perspectives of Canadian- and ForeignBorn Volunteers." Canadian Journal of Nonprofit and Social Economy Research 3, no. 2 (Autumn 2012): 6-23.

Beiser, Morton. "Sponsorship and Resettlement Success." Journal of International Migration and Integration 4, no. 2 (2003): 203-215. https://doi.org/10.1007/s12134-003-1033-z.

Bond, Jennifer, Giulio Di Blasi, and Ania Kwadrans. "The Future of Community Sponsorship of Refugees: Meeting COVID-19's Challenges.” Kaldor Centre for International Refugee Law Blog, May 25, 2020. https://www.kaldorcentre.unsw.edu.au/publication/future-communitysponsorship-refugees-meeting-covid-19s-challenges.

Bond, Jennifer, and Ania Kwadrans. "Resettling Refugees through Community Sponsorship: A Revolutionary Operational Approach Built on Traditional Legal Infrastructure." Refuge: Canada's Journal on Refugees 35, no. 2 (June 2019): 86108.

Bradley, Andrea. "Beyond Borders: Cosmopolitanism and Family Reunification for Refugees in Canada." International Journal of Refugee Law 22, no. 3 (2010): 379-403. https://doi.org/10.1093/ijrl/eeq025. 
Bradley, Megan, and Cate Duin. "A Port in the Storm: Resettlement and Private Sponsorship in the Broader Context of the Refugee Regime." In Strangers to Neighbours: Refugee Sponsorship in Context, edited by Shauna Labman and Geoffrey Cameron. Montreal: McGill-Queen's University Press, forthcoming 2020 .

Cameron, Geoffrey. "Reluctant Partnership: A Political History of Private Sponsorship in Canada (1947-1980).” In Strangers to Neighbours: Refugee Sponsorship in Context, edited by Shauna Labman and Geoffrey Cameron. Montreal: McGillQueen's University Press, forthcoming 2020.

Canadian Council for Refugees. "2017 Immigration Levels - Comments." Canadian Council for Refugees. Accessed January 19, 2019. https://ccrweb.ca/en/2017immigration-levels-comments.

. "Assisted Relatives.” November 2004. https://ccrweb.ca/en/res/assistedrelatives.

. "Comments on Proposed Changes to the Transportation Loan." October 2017. https://ccrweb.ca/sites/ccrweb.ca/files/transportation-loans-comments.pdf.

. "Priorities for Refugees and Vulnerable Migrants 2019." April 1, 2019. https://ccrweb.ca/sites/ccrweb.ca/files/advocacy-priorities-2019.pdf.

. "Renewing Canada's Private Sponsorship of Refugees Program.” January 13, 2016. https://ccrweb.ca/sites/ccrweb.ca/files/renewing-psr-jan-2016.pdf. . "Statement on Blended Visa Office Referred Refugees." July 21, 2016. https://ccrweb.ca/en/BVOR-statement.

. "The Private Sponsorship of Refugees Program: Current Challenges and Opportunities." Canadian Council for Refugees, April 2006.

https://ccrweb.ca/en/private-sponsorship-refugees-program-current-challengesand-opportunities.

Canadian Council for Refugees and Sponsorship Agreement Holder representatives. "Comments on Private Sponsorship of Refugees Evaluation." Canadian Council for Refugees, September 2007. https://ccrweb.ca/files/psrevalcomments.pdf.

Canadian Immigration Historical Society. "Presentation: (1986) UNHCR Nansen Refugee Award to the people of Canada." Canadian Immigration Historical Society, February 18, 2014. http://cihs-shic.ca/unhcr-nansen-refugee-award/.

Casasola, Michael. "The Indochinese Refugee Movement and the Subsequent Evolution of UNHCR and Canadian Resettlement Selection Policies and Practices." Refuge: Canada's Journal on Refugees 32, no. 2 (July 2016): 41-53.

Chan, Kwok, and Lawrence Lam. "Resettlement of Vietnamese-Chinese Refugees in Montreal, Canada: Some Socio-Psychological Problems and Dilemmas." Canadian Ethnic Studies 15, no. 1 (January 1983): 1-17.

Citizenship and Immigration Canada. "2011-2012 Departmental Performance Report." Ottawa: Citizenship and Immigration Canada, 2012. . "2012-2013 Departmental Performance Report." Ottawa: Citizenship and Immigration Canada, 2013. https://www.canada.ca/en/immigration-refugeescitizenship/corporate/publications-manuals/departmental-performancereports/2013.html. 
. "Building on a Strong Foundation for the 21st Century: New Directions for Immigration and Refugee Policy and Legislation." Citizenship and Immigration Canada, 1998. http://publications.gc.ca/collections/Collection/Ci51-86-1998E.pdf. . "Canada and Anglican Church Give 50 Refugee Families New Hope." Government of Canada News Releases. February 9, 2012. https://www.canada.ca/en/news/archive/2012/02/canada-anglican-church-give-50refugee-families-new-hope.html.

_ . "Canada's Commitment to Iraqi Refugees Remains Strong." Government of Canada News Releases. March 18, 2011. https://www.canada.ca/en/news/archive/2011/03/canada-commitment-iraqirefugees-remains-strong.html.

. "Government of Canada and the Anglican Church of Canada Encourage Canadians to Sponsor Refugees." Government of Canada News Release. April 16, 2009. https://www.canada.ca/en/news/archive/2009/04/government-canadaanglican-church-canada-encourage-canadians-sponsor-refugees.html.

Dauvergne, Catherine. Humanitarianism, Identity, and Nation: Migration Laws in Canada and Australia. Vancouver: UBC Press, 2005.

Derwing, Tracey M., and Marlene Mulder. "The Kosovar Sponsoring Experience in Northern Alberta." Journal of International Migration and Integration 4, no. 2 (December 1, 2003): 217-36. https://doi.org/10.1007/s12134-003-1034-y.

Drolet, Julie, and Gayatri Moorthi. "The Settlement Experiences of Syrian Newcomers in Alberta: Social Connections and Interactions." Canadian Ethnic Studies 50, no. 2 (August 2018): 101-20. https://doi.org/10.1353/ces.2018.0017.

Edwards, Michael, and Simon Zadek. "Governing the Provision of Global Public Goods: The Role and Legitimacy of Nonstate Actors." In Providing Global Public Goods: Managing Globalization, edited by Inge Kaul, 200-224. New York: Oxford University Press, 2003. http://www.oxfordscholarship.com/view/10.1093/0195157400.001.0001/acprof9780195157406.

Enns, Thea. "The Opportunity to Welcome: Shifting Responsibilities and the

Resettlement of Syrian Refugees within Canadian Communities." Master's thesis, University of Oxford, 2017.

https://www.academia.edu/37800132/The_Opportunity_to_Welcome_Shifting_re sponsibilities_and_the_resettlement_of_Syrian_refugees_within_Canadian_comm unities.

Enns, Thea, Luann Good Gingrich, and Kaylee Perez. "Religious Heritage, Institutionalized Ethos, and Synergies: Mennonite Central Committee and Canada's Private Sponsorship of Refugees Program.” In Strangers to Neighbours: Refugee Sponsorship in Context, edited by Shauna Labman and Geoffrey Cameron. Montreal: McGill-Queen's University Press, forthcoming 2020.

Evaluation Division. "Evaluation of Government Assisted Refugees (GAR) and Resettlement Assistance Program (RAP)." Ottawa: Citizenship and Immigration Canada, 2011. http://publications.gc.ca/collections/collection_2012/cic/Ci4-692011-eng.pdf.

. "Evaluation of the Host Program." Ottawa: Citizenship and Immigration Canada, 2010. 
https://www.canada.ca/content/dam/ircc/migration/ircc/english/pdf/researchstats/2010-eval-host-eng.pdf.

. "Evaluation of the Resettlement Programs (GAR, PSR, BVOR and RAP)."

Ottawa: IRCC, July 2016.

https://www.canada.ca/content/dam/ircc/migration/ircc/english/pdf/pub/resettleme nt.pdf.

. "Evaluation of the Settlement Program." Ottawa: Immigration, Refugees and Citizenship Canada, November 2017.

https://www.canada.ca/content/dam/ircc/documents/pdf/english/evaluation/e22016-settlement-en.pdf.

. "Rapid Impact Evaluation of the Syrian Refugee Initiative." Ottawa:

Immigration, Refugees and Citizenship Canada, December 2016.

https://www.canada.ca/en/immigration-refugees-citizenship/corporate/reportsstatistics/evaluations/rapid-impact-evaluation-syrian-refugee-initiative.html.

. "Syrian Outcomes Report." Ottawa: Immigration, Refugees and Citizenship Canada, June 2019.

https://www.canada.ca/content/dam/ircc/documents/pdf/english/corporate/reportsstatistics/evaluations/syria-outcomes-report-may-2019.pdf.

Fratzke, Susan and Emma Dorst. "Volunteers and Sponsors: A Catalyst for Refugee Integration?" Migration Policy Institute, November 25, 2019.

https://www.migrationpolicy.org/research/volunteers-sponsors-refugeeintegration.

Garnier, Adèle, Liliana Lyra Jubilut, and Kristin Bergtora Sandvik. "Introduction: Refugee Resettlement as Humanitarian Governance: Power Dynamics.” In Refugee Resettlement: Power, Politics, and Humanitarian Governance, edited by Adèle Garnier, Liliana Lyra Jubilut, and Kristin Bergtora Sandvik, 1-27. New York: Berghahn Books, 2018.

Ghahari, Setareh, Josie Lui, Satmeen Nagra, and Sara Morassaei. "The Life Experiences of Refugees in Canada: A Comprehensive Scoping Review to Identify Unmet Needs and Barriers." Journal of International Migration and Integration, November 2019. https://doi.org/10.1007/s12134-019-00727-3.

Gilligan, Carol. In a Different Voice: Psychological Theory and Women's Development. Cambridge: Harvard University Press, 1982.

Global Refugee Sponsorship Initiative. "Who We Are." Global Refugee Sponsorship Initiative. Accessed February 19, 2018. http://refugeesponsorship.org/who-weare.

Government of Canada. "Canada: A History of Refuge." Government of Canada. Last modified January 16, 2020. https://www.canada.ca/en/immigration-refugeescitizenship/services/refugees/canada-role/timeline.html. . Immigration Act, C.52 (1976). Accessed January 31, 2020. https://pier21.ca/research/immigration-history/immigration-act-1976. . Immigration and Refugee Protection Act, S.C. 2001, c. 27. Last amended July 31, 2018. http://laws-lois.justice.gc.ca/eng/acts/I-2.5/page-1.html\#h-3. . Immigration and Refugee Protection Regulations, SOR/2002-227. Last amended August 15, 2019. https://laws-lois.justice.gc.ca/PDF/SOR-2002-227.pdf. 
_. "Sponsor a Refugee." Government of Canada. Last modified December 3, 2019. https://www.canada.ca/en/immigration-refugees-

citizenship/services/refugees/help-outside-canada/private-sponsorshipprogram.html.

. "\#WelcomeRefugees: Key Figures.” Government of Canada. Last modified February 27, 2017. https://www.canada.ca/en/immigration-refugeescitizenship/services/refugees/welcome-syrian-refugees/key-figures.html. . "\#WelcomeRefugees: The Journey to Canada." Government of Canada. Last modified November 28, 2016. https://www.canada.ca/en/immigration-refugeescitizenship/services/refugees/welcome-syrian-refugees/infographic.html.

Hammond, Scott. Political Theory: An Encyclopedia of Contemporary and Classic Terms. Westport: ABC-CLIO, LLC, 2008.

Hanisch, Carol. “The Personal Is Political.” Writings by Carol Hanisch, 2009. http://www.carolhanisch.org/CHwritings/PIP.html.

Held, Virginia. The Ethics of Care: Personal, Political, and Global. Oxford: Oxford University Press, 2006.

Hutchinson, Anna. "Welcome to Canada': Hospitality, Inclusion and Diversity in Private Refugee Sponsorship.” UCL Migration Research Unit Working Papers, no. 2 (2018).

Hyndman, Jennifer. "Unsettling Feminist Geopolitics: Forging Feminist Political Geographies of Violence and Displacement." Gender, Place \& Culture, May 2019, 1-27. https://doi.org/10.1080/0966369X.2018.1561427.

Hyndman, Jennifer, William Payne, and Shauna Jimenez. "The State of Private Refugee Sponsorship in Canada: Trends, Issues, and Impacts.” Refugee Research Network and York University Centre for Refugee Studies, December 2, 2016.

http://refugeeresearch.net/wpcontent/uploads/2017/02/hyndman_feb\%E2\%80\%9917.pdf.

Hynie, Michaela, Susan McGrath, Jonathān Bridekirk, Anna Oda, Nicole Ives, Jennifer Hyndman, Neil Arya, Yogendra B. Shakya, Jill Hanley, and Kwame McKenzie. "What Role Does Type of Sponsorship Play in Early Integration Outcomes? Syrian Refugees Resettled in Six Canadian Cities." Refuge: Canada's Journal on Refugees 35, no. 2 (June 5, 2019): 36-52.

Ilcan, Suzan, and Tanya Basok. "Community Government: Voluntary Agencies, Social Justice, and the Responsibilization of Citizens." Citizenship Studies 8, no. 2 (June 2004): 129-44. https://doi.org/10.1080/1362102042000214714.

Immigration, Refugees and Citizenship Canada. "Evaluation of the Immigration Loan Program.” Ottawa: IRCC, December 14, 2015. https://www.canada.ca/en/immigration-refugees-citizenship/corporate/reportsstatistics/evaluations/immigration-loan-program.html.

. "Notice - Supplementary Information 2020-2022 Immigration Levels Plan." Government of Canada, March 12, 2020. https://www.canada.ca/en/immigrationrefugees-citizenship/news/notices/supplementary-immigration-levels-2020.html. . "Resettlement Assistance Program (RAP)." Www.canada.ca/en/immigrationrefugees-citizenship/corporate/publications-manuals/operational-bulletinsmanuals/service-delivery/resettlement-assistance-program.html. Government of Canada. Last modified June 19, 2019. 
—_ “2017-2018 Departmental Results Report.” Ottawa: Immigration, Refugees and Citizenship Canada, 2018. https://www.canada.ca/en/immigration-refugeescitizenship/corporate/publications-manuals/departmental-performancereports/2018.html.

. "By the Numbers - 40 Years of Canada's Private Sponsorship of Refugees Program." Government of Canada, April 9, 2019.

https://www.canada.ca/en/immigration-refugees-citizenship/news/2019/04/by-thenumbers--40-years-of-canadas-private-sponsorship-of-refugees-program.html. . "Canada Announces New Initiative to Support LGBTQ2 Refugees." Government of Canada News Releases. June 1, 2019. https:/www.canada.ca/en/immigration-refugeescitizenship/news/2019/06/canada-announces-new-initiative-to-support-lgbtq2refugees.html.

. "Canada Celebrates 40 Years of the Refugee Sponsorship Program." Government of Canada Newsroom. April 9, 2019.

https://www.canada.ca/en/immigration-refugees-

citizenship/news/2019/04/canada-celebrates-40-years-of-the-refugee-sponsorshipprogram.html.

. "Find Help to Adjust - Refugees." Government of Canada. Last modified

November 13, 2018. https:/www.canada.ca/en/immigration-refugees-

citizenship/services/refugees/help-within-canada/government-assisted-refugeeprogram/providers.html.

_ . "Guide to the Private Sponsorship of Refugees Program." Government of Canada. Last modified January 14, 2019. https://www.canada.ca/en/immigrationrefugees-citizenship/corporate/publications-manuals/guide-private-sponsorshiprefugees-program.html.

. "Helping Vulnerable Yazidi Women and Children and Other Survivors of

Daesh.” Backgrounders. Government of Canada, February 21, 2017.

https://www.canada.ca/en/immigration-refugees-

citizenship/news/2017/02/helping_vulnerableyazidiwomenandchildrenandothersu rvivorsofdaesh.html.

. "Immigration Operational Bulletin 646 (Modified) - Joint Assistance Sponsorship Recommendations from within Canada." Government of Canada, December 6, 2017. https://www.canada.ca/en/immigration-refugeescitizenship/corporate/publications-manuals/operational-bulletinsmanuals/bulletins-2017/646.html.

. "Notice - Supplementary Information 2018-2020 Immigration Levels Plan."

Government of Canada, November 1, 2017.

https:/www.canada.ca/en/immigration-refugees-

citizenship/news/notices/supplementary-immigration-levels-2018.html.

. "Notice - Supplementary Information 2019-2021 Immigration Levels Plan."

Government of Canada, October 31, 2018.

https://www.canada.ca/en/immigration-refugees-

citizenship/news/notices/supplementary-immigration-levels-2019.html.

. "Private Sponsorship of Refugees Program - Sponsorship Agreement Holders." Government of Canada. Last modified November 25, 2019. 
https://www.canada.ca/en/immigration-refugees-

citizenship/services/refugees/help-outside-canada/private-sponsorship-

program/agreement-holders/holders-list.html\#tbl.

_. "Refugee Sponsorship Application: Joint Assistance Sponsorship (IMM 5493)."

Government of Canada, March 31, 2017. https://www.canada.ca/en/immigrationrefugees-citizenship/services/application/application-forms-guides/guide-5493-

refugee-sponsorship-application-joint-assistance-sponsorship.html.

Jamieson, Beals, Lalonde \& Associates. "Evaluation of the 3/9 Refugee Sponsorship Programme Final Report.” Ottawa, July 1996. Canadian Official Publications. Library and Archives Canada.

Janzen, William. "The 1979 MCC Canada Master Agreement for the Sponsorship of Refugees in Historical Perspective." Journal of Mennonite Studies, no. 24 (2006): $211-22$.

Jedwab, Jack. "GARs vs. PSRs: Explaining Differences in Outcomes for Recent Refugees to Canada." Canadian Diversity 15, no. 2 (January 2018).

Kaduuli, Stephen. "Continuing Welcome: A Progress Report on a Half Welcome." Ottawa: Citizens for Public Justice, June 2020. https://cpj.ca/wpcontent/uploads/2020/06/Continuing-Welcome.pdf.

Kaida, Lisa, Feng Hou, and Max Stick. "The Long-Term Economic Integration of Resettled Refugees in Canada: A Comparison of Privately Sponsored Refugees and Government-Assisted Refugees." Journal of Ethnic and Migration Studies 46, no. 9 (July 2020): 1687-1708. https://doi.org/10.1080/1369183X.2019.1623017.

Kelley, Ninette, and Michael Trebilcock. The Making of the Mosaic: A History of Canadian Immigration Policy. 2nd ed. Toronto: University of Toronto Press, 2010.

Krivenko, Ekaterina Yahyaoui. "Hospitality and Sovereignty: What Can We Learn From the Canadian Private Sponsorship of Refugees Program?" International Journal Of Refugee Law 24, no. 3 (2012): 579-602. https://doi.org/10.1093/ijrl/ees039.

Kyriakides, Christopher, Lubna Bajjali, Arthur McLuhan, and Karen Anderson. "Beyond Refuge: Contested Orientalism and Persons of Self-Rescue." Canadian Ethnic Studies 50, no. 2 (August 2018): 59-78. https://doi.org/10.1353/ces.2018.0015.

Kyriakides, Christopher, Arthur McLuhan, Karen Anderson, and Lubna Bajjali. "Status Eligibilities: The Eligibility to Exist and Authority to Act in Refugee-Host Relations." Social Forces, 2018. https://doi.org/10.1093/sf/soy109.

. "Transactions of Worth in Refugee-Host Relations." In Strangers to Neighbours: Refugee Sponsorship in Context, edited by Shauna Labman and Geoffrey Cameron. Montreal: McGill-Queen's University Press, forthcoming 2020.

Labman, Shauna. “Conclusion: Sponsorship's Success and Sustainability?” In Strangers to Neighbours: Refugee Sponsorship in Context, edited by Shauna Labman and Geoffrey Cameron. Montreal: McGill-Queen's University Press, forthcoming 2020.

- Crossing Law's Border: Canada's Refugee Resettlement Program. Law and Society Series. Vancouver: UBC Press, 2019.

. "Private Sponsorship: Complementary or Conflicting Interests?" Refuge: Canada's Journal on Refugees 32, no. 2 (2016): 67-80. 
Labman, Shauna, and Jennifer Hyndman. "BVOR Briefing Note.” Centre for Refugee Studies, York University, May 1, 2019. https://crs.info.yorku.ca/files/2019/04/BVOR-Briefing-2019-May1.pdf.

Labman, Shauna, and Madison Pearlman. "Blending, Bargaining, and Burden-Sharing: Canada's Resettlement Programs." Journal of International Migration and Integration, February 17, 2018, 1-11. https://doi.org/10.1007/s12134-018-0555-3.

Lehr, Sabine, and Brian Dyck. "NNaming' Refugees in the Canadian Private Sponsorship of Refugees Program: Diverse Intentions and Consequences." In Strangers to Neighbours: Refugee Sponsorship in Context, edited by Shauna Labman and Geoffrey Cameron. Montreal: McGill-Queen's University Press, forthcoming 2020.

Lenard, Patti Tamara. "How Do Sponsors Think about 'Month 13'?" Refuge: Canada's Journal on Refugees 35, no. 2 (June 2019): 64-73.

_. "How Should We Think about Private Sponsorship of Refugees?" In Strangers to Neighbours: Refugee Sponsorship in Context, edited by Shauna Labman and Geoffrey Cameron. Montreal: McGill-Queen's University Press, forthcoming 2020 .

. "Resettling Refugees: Is Private Sponsorship a Just Way Forward?" Journal of Global Ethics 12, no. 3 (September 2016): 300-310. https://doi.org/10.1080/17449626.2016.1247290.

Lim, Desiree. "Social Egalitarianism and the Private Sponsorship of Refugees." Journal of Social Philosophy 50, no. 3 (2019): 301-21. https://doi.org/10.1111/josp.12294.

Lippert, Randy. "Rationalities and Refugee Resettlement." Economy and Society 27, no. 4 (1998): 380-406. https://doi.org/10.1080/03085149800000026.

Macklin, Audrey, Kathryn Barber, Luin Goldring, Jennifer Hyndman, Anna Korteweg, Shauna Labman, and Jona Zyfi. "A Preliminary Investigation into Private Refugee Sponsors.” Canadian Ethnic Studies 50, no. 2 (August 13, 2018): 35-57. https://doi.org/10.1353/ces.2018.0014.

Macklin, Audrey, Kathryn Barber, Luin Goldring, Jennifer Hyndman, Anna Korteweg, and Jona Zyfi. "Kindred Spirits? Links Between Refugee Sponsorship and Family Sponsorship." In Strangers to Neighbours: Refugee Sponsorship in Context, edited by Shauna Labman and Geoffrey Cameron. Montreal: McGill-Queen's University Press, forthcoming 2020.

Mas, Susana. "Canada to Resettle 10,000 More Syrian Refugees over 3 Years." CBC News, January 7, 2015. https://www.cbc.ca/news/politics/canada-to-resettle-10000-more-syrian-refugees-over-3-years-1.2892652.

Mattie, Jordan. A Resettlement Story: The Saint John Syrian Refugee Response. Saint John, New Brunswick, 2017. https://www.youtube.com/watch?v=7KNmfH7MxkA\&t=236s.

McNally, Rachel. "15 Ways to Evaluate the Success of Community Sponsorship Programs." Canadian Association for Refugee and Forced Migration Studies Blog, January 22, 2020. http://carfms.org/15-ways-to-evaluate-the-success-ofcommunity-sponsorship-programs-by-rachel-mcnally/. 
—. "Community Refugee Sponsorship and Integration in Rural Nova Scotia." Honours thesis, Acadia University, 2018. https://scholar.acadiau.ca/islandora/object/theses\%3A2643/. . "The Blended Visa Office-Referred Program: Perspectives and Experiences from Rural Nova Scotia." In Strangers to Neighbours: Refugee Sponsorship in Context, edited by Shauna Labman and Geoffrey Cameron. Montreal: McGillQueen's University Press, forthcoming 2020.

Milner, James. "Can Global Refugee Policy Leverage Durable Solutions? Lessons from Tanzania's Naturalization of Burundian Refugees." Journal of Refugee Studies 27, no. 4 (December 2014): 553-73. https://doi.org/10.1093/jrs/feu023.

—. "Refugees, Peacebuilding, and Paternalism: Lessons from Mozambique." In Refugees' Roles in Resolving Displacement and Building Peace: Beyond Beneficiaries, edited by Megan Bradley, James Milner, and Blair Peruniak, 11531. Washington: Georgetown University Press, 2019.

Milner, James, and Krystyna Wojnarowicz. "Power in the Global Refugee Regime: Understanding Expressions and Experiences of Power in Global and Local Contexts." Refuge: Canada's Journal on Refugees 33, no. 1 (March 2017): 7-17. Minister of Citizenship and Immigration. "Report on Plans and Priorities 2014-2015." Ottawa: Citizenship and Immigration Canada, 2014. https://www.canada.ca/content/dam/ircc/migration/ircc/english/pdf/pub/rpp-20142015.pdf.

Minister of Immigration, Refugees and Citizenship. "2019 Annual Report to Parliament on Immigration.” Ottawa: Immigration, Refugees and Citizenship Canada, 2019. https://www.canada.ca/content/dam/ircc/migration/ircc/english/pdf/pub/annualreport-2019.pdf.

. "Annual Report to Parliament on Immigration 2017.” Ottawa: IRCC, 2017. https://www.canada.ca/content/dam/ircc/migration/ircc/english/pdf/pub/annualreport-2017.pdf.

. "Departmental Plan 2019-2020." Ottawa: Immigration, Refugees and Citizenship Canada, 2019.

https://www.canada.ca/content/dam/ircc/migration/ircc/english/pdf/pub/dp-pm2019-2020-eng.pdf.

Molloy, Michael, Peter Duschinsky, Kurt Jensen, and Robert Shalka. Running on Empty: Canada and the Indochinese Refugees, 1975-1980. McGill-Queen's Studies in Ethnic History 41. Montreal: McGill-Queen's University Press, 2017.

Molloy, Michael, and James Simeon. "The Indochinese Refugee Movement and the Launch of Canada's Private Sponsorship Program." Refuge: Canada's Journal on Refugees 32, no. 2 (July 2016): 3-8.

Nyers, Peter. Rethinking Refugees: Beyond States of Emergency. Global Horizons. New York: Routledge, 2006.

OCASI. "Allies in Refugee Integration." OCASI: Ontario Council of Agencies Serving Immigrants. Accessed March 29, 2020. https://ocasi.org/allies-refugeeintegration.

Oda, Anna, Michaela Hynie, Andrew Tuck, Branka Agic, Brenda Roche, and Kwame McKenzie. "Differences in Self-Reported Health and Unmet Health Needs Between Government Assisted and Privately Sponsored Syrian Refugees: A 
Cross-Sectional Survey." Journal of Immigrant and Minority Health 21, no. 3

(June 1, 2019): 439-42. https://doi.org/10.1007/s10903-018-0780-z.

Operation Ezra. "Yazidi Rescue Program Highlights." Operation Ezra, December 19, 2016.

Pearlman, Madison. "Operation Ezra: A New Way Forward.” In Strangers to Neighbours: Refugee Sponsorship in Context, edited by Shauna Labman and Geoffrey Cameron. Montreal: McGill-Queen's University Press, 2020.

Refugee Hub. "2018 BVOR Fund Sponsor Experience Survey.” Refugee Hub, 2019. https://docs.google.com/presentation/d/1aj36S4oNrMoLi4RH0Q_coCdKuiVaYV 3hDILGopg7WtU/edit?usp=sharing\&usp=embed_facebook. . "News Release: Hundreds of Refugees to Settle in Canada by Year's End after Receipt of \$3.5 Million in Donations Ensures Community Sponsorship Spaces Are Filled." The Refugee Hub. November 14, 2018. https://refugeehub.ca/newsrelease-hundreds-of-refugees-to-settle-in-canada-by-years-end-after-receipt-of-35-million-in-donations-ensures-community-sponsorship-spaces-are-filled/.

. "PRESS RELEASE: Funds Now Available for Canadians to Sponsor Hundreds of Refugees in 2019." The Refugee Hub. May 2, 2019.

https://refugeehub.ca/press-release-funds-now-available-for-canadians-tosponsor-hundreds-of-refugees-in-2019/.

Refugee Sponsorship Training Program. "Blended Visa Office Referred (BVOR) Program Frequently Asked Questions," 2017. http://www.rstp.ca/wpcontent/uploads/2014/03/Blended-VOR-FAQ_2017-1-1.pdf.

. "BVOR News.” Refugee Sponsorship Training Program, January 2019. http://www.rstp.ca/wp-content/uploads/2019/07/BVOR-news-7-January2019.pdf.

. "JAS Refugee Profiles." RSTP. Accessed September 4, 2019. http://www.rstp.ca/en/jas/jas-profiles/.

. "PSR Post-Arrival Assurance Activities.” Refugee Sponsorship Training Program, January 7, 2020. http://www.rstp.ca/wp-content/uploads/2020/01/PSRPost-Arrival-Assurance-Activities-Jan-2020.pdf.

. "The Joint Assistance Sponsorship (JAS) Program.” RSTP. Accessed May 24, 2020. http://www.rstp.ca/en/jas/joint-assistance-sponsorships/.

Reynolds, Johanna, and Christina Clark-Kazak. "Introduction: Special Issue on Private Sponsorship in Canada." Refuge: Canada's Journal on Refugees 35, no. 2 (September 2019): 3-8.

Ritchie, Genevieve. "Civil Society, the State, and Private Sponsorship: The Political Economy of Refugee Resettlement." International Journal of Lifelong Education 37, no. 6 (November 2018): 663-75. https://doi.org/10.1080/02601370.2018.1513429.

Robinson, Fiona. "Feminist Care Ethics and Everyday Insecurities." In Ethical Security Studies: A New Research Agenda, edited by Jonna Nyman and Anthony Burke. Routledge Critical Security Studies Series. Abingdon: Routledge, 2016. - "Global Ethic of Care." Oxford Bibliographies Online, July 27, 2016. https://doi.org/10.1093/OBO/9780199743292-0182. 
_ . "Stop Talking and Listen: Discourse Ethics and Feminist Care Ethics in International Political Theory." Millennium - Journal of International Studies 39, no. 3 (2011): 845-860. https://doi.org/10.1177/0305829811401176.

- The Ethics of Care: A Feminist Approach to Human Security. Global Ethics and Politics. Philadelphia: Temple University Press, 2011.

Rose, Debbie, and Gary Rose. "Report on the Challenges of the Yazidi Refugees." Project Abraham, Mozuud Resettlement and Support for Victims of Persecution, December 1, 2017.

Rubin, Herbert, and Irene Rubin. Qualitative Interviewing: The Art of Hearing Data. 3rd ed. Thousand Oaks: SAGE, 2012.

Salamon, Lester M. "The Resilient Sector: The State of the Nonprofit America." In The State of Nonprofit America, edited by Lester M. Salamon, 3-64. Washington: Brookings Institution Press, 2002.

Selm, Joanne van. "Public-Private Partnerships in Refugee Resettlement: Europe and the US." Journal of International Migration and Integration 4, no. 2 (December 1, 2003): 157-75. https://doi.org/10.1007/s12134-003-1031-1.

Senthanar, Sonja, Ellen MacEachen, Stephanie Premji, and Philip Bigelow.

"Employment Integration Experiences of Syrian Refugee Women Arriving through Canada's Varied Refugee Protection Programmes." Journal of Ethnic and Migration Studies (March 1, 2020): 1-21.

https://doi.org/10.1080/1369183X.2020.1733945.

Sherrell, Kathy, and Jennifer Hyndman. "Sharing the Wealth, Spreading the 'Burden'? The Settlement of Kosovar Refugees in Smaller British Columbia Cities." Canadian Ethnic Studies 37, no. 3 (2005): 76-96.

Silvius, Ray. "Neo-Liberalization, Devolution, and Refugee Well-Being: A Case Study in Winnipeg, Manitoba." Canadian Ethnic Studies 48, no. 3 (2016): $27-44$. https://doi.org/10.1353/ces.2016.0024.

. "Work, Social Reproduction, the Transnational Household, and Refugee Resettlement: A Canadian Case Study:" Critical Sociology, February 15, 2019. https://doi.org/10.1177/0896920518820936.

Smith, Craig Damian. "A Model for the World? Policy Transfer Theory and the Challenges to 'Exporting' Private Sponsorship to Europe." In Strangers to Neighbours: Refugee Sponsorship in Context, edited by Shauna Labman and Geoffrey Cameron. Montreal: McGill-Queen's University Press, forthcoming 2020.

Smith, Craig Damian, Tea Hadžiristić, and Lina Alipour. "Filling the Gap: Volunteer \& Settlement Sector Interactions In Response to the Syrian Refugee Crisis." Toronto: Together Project, September 2017. https://togetherproject.ca/site/uploads/2018/03/Together_Project_Report_Filling_t he_Gap.pdf.

Standing Committee on Citizenship and Immigration. "Evidence." 42nd Parliament, 1st Session. House of Commons of Canada, November 30, 2017. https://www.ourcommons.ca/DocumentViewer/en/42-1/CIMM/meeting88/evidence\#Int-9820056.

Together Project. "Matching.” Together Project. Accessed March 28, 2020. https://togetherproject.ca/matching/. 
Treviranus, Barbara, and Michael Casasola. "Canada's Private Sponsorship of Refugees Program: A Practitioners Perspective of Its Past and Future." Journal of International Migration and Integration 4, no. 2 (December 2003): 177-202. http://dx.doi.org/10.1007/s12134-003-1032-0.

Tronto, Joan. "Democratic Caring and Global Care Responsibilities." In Ethics of Care: Critical Advances in International Perspective, edited by Marian Barnes, Tula Brannelly, Lizzie Ward, and Nicki Ward, 21-30. Bristol: Policy Press, 2015.

- Moral Boundaries: A Political Argument for an Ethic of Care. New York: Routledge, 1993.

Türegün, Adnan. "Immigrant Settlement Work in Canada: Limits and Possibilities for Professionalization." Canadian Review of Sociology 50, no. 4 (November 2013): 387-411. https://doi.org/10.1111/cars.12025.

Tyyskä, Vappu, Jenna Blower, Samantha Deboer, Shunya Kawai, and Ashley Walcott. "Canadian Media Coverage of the Syrian Refugee Crisis: Representation, Response, and Resettlement." Geopolitics, History and International Relations 10, no. 1 (2018): 148-66. https://doi.org/10.22381/GHIR10120187.

United Nations High Commissioner for Refugees. "Convention and Protocol Relating to the Status of Refugees." UNHCR, December 2010.

https://www.unhcr.org/protection/basic/3b66c2aa10/convention-protocol-relatingstatus-refugees.html.

. "Global Trends: Forced Displacement in 2019." Copenhagen, Denmark: UNHCR, June 18, 2020. https://www.unhcr.org/5ee200e37.pdf. . "Resettlement Data Finder." UNHCR, March 31, 2020. https://rsq.unhcr.org/. . Resettlement Handbook. UNHCR, 2011. https://www.unhcr.org/46f7c0ee2.html. . "Statute of the Office of the United Nations High Commissioner for Refugees." UNHCR, October 2010.

https://www.unhcr.org/protection/basic/3b66c39e1/statute-office-united-nationshigh-commissioner-refugees.html.

. "The Integration of Resettled Refugees: Essentials for Establishing a Resettlement Programme and Fundamentals for Sustainable Resettlement Programmes." UNHCR, 2013. https://www.unhcr.org/52a6d85b6.pdf. . "States Parties to the 1951 Convention and Its 1967 Protocol," April 2015. https://www.unhcr.org/protection/basic/3b73b0d63/states-parties-1951convention-its-1967-protocol.html.

Vaittinen, Tiina. "The Power of the Vulnerable Body." International Feminist Journal of Politics 17, no. 1 (January 2015): 100-118. https://doi.org/10.1080/14616742.2013.876301.

Vogl, Anthea, Khanh Hoang, and Asher Hirsch. "Private Humanitarian Sponsorship: Searching for the Community in Australia's Community Refugee Sponsorship Program." In Strangers to Neighbours: Refugee Sponsorship in Context, edited by Shauna Labman and Geoffrey Cameron. Montreal: McGill-Queen's University Press, forthcoming 2020.

Williams, Fiona. "Care: Intersections of Scales, Inequalities and Crises." Current Sociology 66, no. 4 (July 2018): 547-61. https://doi.org/10.1177/0011392118765206. 
Zetter, Roger. "Labelling Refugees: Forming and Transforming a Bureaucratic Identity." Journal of Refugee Studies 4, no. 1 (January 1991): 39-62. https://doi.org/10.1093/jrs/4.1.39. . "More Labels, Fewer Refugees: Remaking the Refugee Label in an Era of Globalization." Journal of Refugee Studies 20, no. 2 (June 2007): 172-92. https://doi.org/10.1093/jrs/fem011. 